
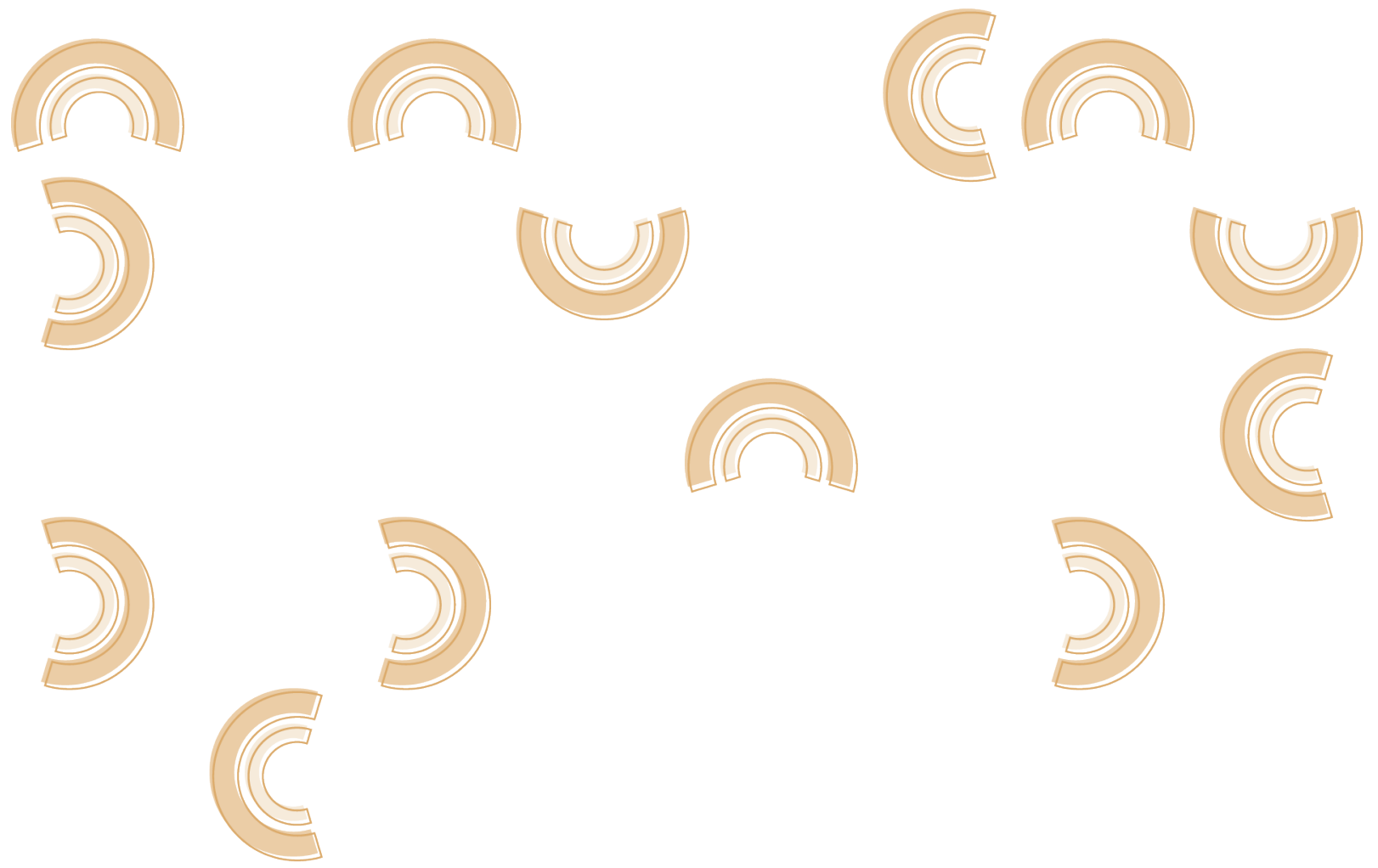

TEXTOS E VERSÕES

WASSILY KANDINSKY

COMPOSIÇÕES PARA PALCO E TEXTOS

TEÓRICO-DRAMATÚRGICOS ${ }^{1}$

\title{
Anabela Mendes
}

Professora da Faculdade de Letras da Universidade de Lisboa. É tradudora, ensaísta, dramaturgista, dramaturga e encenadora.

Universidade de Lisboa

E-mail:anmendes@netcabo.pt

DOI: https://doi.org/10.26512/dramaturgias.voi9.24911 


\section{RESUMO}

Tradução de todas Composições para o Palco elaboradas por Wassily Kandinsky e textos teóricos relacionados.

Palavras-chave: Composições para palco. Autonomia da obra de arte. União das artes. Bidimensionalidade. Tridimensionalidade. Sonoridade interior. Necessidade interior. Arte como fonte de alegria.

\section{ABSTRACT}

Translation of all Wassiliy Kandinsky's Stage Compositions and essays on these artistic works.

Keywords: Stage compositions. Autonomy of the work of art. Union of the arts. Twodimensionality. Tridimensionality. Inner sound. inner necessity. Art as a source ofjoy. 
A obra de arte torna-se sujeito. Como pintura é um organismo espiritual que, à semelhança de um organismo material, é constituída por muitas partes individuais.

Wassily Kandinsky, Pintura como arte pura

Der Sturm, vol. 4, nº 178-179, Setembro de 1913.

\section{NOTA INICIAL}

Estão reunidas neste artigo todas as Composições para Palco criadas por Kandinsky entre os anos de 1909 e 1914. A Composição para Palco Quadros de uma Exposição, inspirada na partitura homónima de Modest Mussorgsky, surgiu posteriormente durante o período de actividade de Kandinsky na Bauhaus.

Agregadas estão também as reflexões teóricas do artista dedicadas a este género performativo.

O trabalho de tradução destes materiais, do alemão para o português, teve como suporte bibliográfico a obra organizada, comentada e ilustrada por Jessica Boissel (ed.) 1998. WASSILY KANDINSKY - ÜBER DAS THEATER DU THÉÂTRE O TEATPE, Köln: Dumont.

É nas Composições para Palco que as questões relacionadas com a materialidade e a espiritualidade se agregam sempre à criação de construção com variados elementos de que vive este tipo de obras, tal como as essencialmente plásticas, com a diferença de que se torna preponderante a presença da tridimensionalidade.

Dotar de subjectividade uma obra de arte é como equipará-la ao seu criador. O acidental, por exemplo, pode ser incorporado a partir da presença de várias versões de uma mesma composição. Quem decide não é o criador sozinho mas o processo que a obra lhe revela. Em Artes do Espectáculo isto faz sentido.

Anabela Mendes

7 de setembro 2018
1 Utiliza-se como fonte para as traduções a obra de Jessica Boissel (ed.), 1998, Wassily Kandinsky-Über das Theater Du Théâtre O Teatpe, Köln, DuMont Verlag. 
NOITEE ${ }^{2}$

$1906-1907$

\section{[1]}

\section{NOITE}

(Estou a escrever. Minette e Vas'ka estão deitados, apertados um contra o outro, em cima da cadeira, junto ao fogão.)

\section{VAS'KA}

De facto, quanto mais cresço, mais antipáticas acho as pessoas. Essa mania parva de lamberem com a mão! Quando o tipo me lambe assim, fico sempre transtornado.

\section{MINETTE}

Eu pura e simplesmente não deixo.

\section{VAS'KA}

É claro! Bem sabes que ele tem por ti um enorme respeito, mas comigo pouco se importa. E o tipo é estúpido, estúpido!.. Inacreditável! Imagina, ainda agora ele acha que quando eu ronrono, isso quer dizer satisfação!!...

\section{MINETTE}

As pessoas são esquisitas! Apesar disso, às vezes percebem perfeitamente que ronronar quer dizer pedir qualquer coisa.

\section{VAS'KA}

O que mais me irrita é a secura das mãos dele. E é assim que ele quer lamber. Com os demónios! Quando penso nisso, fico virado do avesso.

\section{MINETTE}

Olha, vê lá se não aprendes com as pessoas a usar essas expressões idiotas e ainda por cima em alemão! Que mau gosto!

\section{VAS'KA}

Sim, mamã... Mas ao menos deixa-me mamar um pouco em ti! Sim? Deixa, deixa!
2 Trata-se de uma "comédia de gatos", um texto à margem num conjunto de pequenas obras para teatro.

Considerada uma das primeiras tentativas de W. Kandinsky na área teatral em língua alemã, esta comédia felina foi escrita provavelmente em Sèvres, nos arredores de Paris, onde o pintor russo residiu por um ano, a partir de Junho de 1906. Esta residência foi partilhada entre Junho e Novembro desse ano de 1906 com a pintora Gabriele Münter, sua ex-aluna, com quem manteve por um período de quase vinte anos uma intensa e difícil relação afectiva. (N. T.) Todas as notas apresentadas ao longo das Composições para Palco, quando não referenciadas de outra autoria, são da responsabilidade da tradutora. 


\section{MINETTE}

Ele vai zangar-se outra vez.

\section{VAS'KA}

Que o maior cão do mundo o agarre!

\section{MINETTE}

Quem me dera saber em que é que isto lhe diz respeito: não é nele que tu mamas. Sabes, da última vez em que ele se voltou a zangar assim (ele acha que eu percebo, quando ele se põe a falar

o chinês dele!), então fiquei mesmo furiosa e quando ele \{se sentou à mesa de refeições\} e começou a mamar no seu cachimbo fedorento, nessa altura sentei-me ao pé dele e fixei-o, 'tás a ver, fixei-o longamente. Pensei que ele ia compreender. Mas nem sinal. Riu-se apenas e disse que aquilo não era para mim.

\section{VAS'KA}

Ele é mesmo estúpido... Mas lá bater sabe ele!

\section{MINETTE}

Claro, nisso as pessoas são tão perigosas como os cães. Nesses casos o melhor é trepar a uma árvore. E mesmo assim ainda nos mostram os dentes. Só que das pessoas não precisas de ter medo: elas não mordem.

\section{VAS'KA}

Mas a mim ele já mordeu algumas vezes. Palavra de honra, mamã.

\section{MINETTE (pensativa)}

Não, um cão é que ele não é. Primeiro não tem cauda e depois só tem 2 pernas.

\section{VAS'KA}

É estranho como as pessoas são feitas. Neles mal se conseguem ver os olhos e à noite despem a pele. Nem sei como isso não lhes faz doer!?

\section{MINETTE}

Mas o mais esquisito é eles não se conseguirem sentar sem cadeira. 


\section{VAS'KA}

Mamãzinha, por favor, diz lá então quem é afinal o meu pai? Não é aquele homem ali, pois não?

\section{MINETTE}

Cruzes! Vê se tens vergonha! Como tens coragem

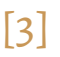

de dizer uma coisa dessas à tua mãe! Credo! Vou desancar-te! Zás! Zás! Zás!

(lambe carinhosamente M.) Perdoa-me, querida, querida mamã. Não te zangues! Tu nunca queres responder a esta pergunta, por isso pensei que tivesse havido qualquer coisa no teu passado...

\section{MINETTE}

Mas não uma coisa dessas. E deixa-me em paz com essas perguntas. Simplesmente encontrei-te na cave.

\section{VAS'KA (tímido)}

E aquele belo vizinho da casa de cima? O Frimms disse-me uma vez...

\section{MINETTE}

O Frimms é um tipo grosseiro. Muitas vezes choro quando penso que ele é o castigo dos meus pecados.

\section{VAS'KA}

E o vizinho?

\section{MINETTE}

Ah, deixa isso. Tu ainda nem \{sequer\} és capaz de distinguir um homem de uma mulher.

\section{VAS'KA}

Sou, pois!

\section{MINETTE}

E qual é a diferença? 
VAS'KA (embaraçado)

Em relação aos gatos, de facto, ainda não sei, mas sei em relação às pessoas.

MINETTE (ri-se e mal consegue falar de tanto rir)

Então...e

ela... seria?

VAS'KA (orgulhoso)

Entre os seres humanos o homem tem 2 pernas e a mulher apenas uma, mas uma muito volumosa. É isso mesmo!!

MINETTE (continuando a rir)

É por isso que eu estou sempre a ler nos nossos romances sobre a perdição da mulher. (em voz baixa) Curioso, mas nós temos quatro pernas e afinal...

[Final ou interrupção do manuscrito que apresenta na última página a seguinte inscrição a lápis feita pela mão de G. Münter:] "Os gatos Minette e Vas'ka em Sèvres/ História de Ka[ndinsky]." 
JARDIM DO PARAÍSO ${ }^{3}$ E ASA MÁGICA

$1908-1909$

\section{[1]}

\section{JARDIM DO PARAÍSO}

Quadro: um Príncipe vê uma estrela que cintila intensamente como a Ilha da Felicidade ao afundar-se na Terra.

Está tudo escuro, excepto o Príncipe e a estrela que vai progressivamente ficando mais brilhante (Música).

A luz da estrela torna visível uma caverna.

Morte: e todos os mil anos trá-lo-ei de novo à vida. (5")

Morte como no desenho na sala de canto. Príncipe - segundo o esboço azul celeste para impressão.

Jardim do Paraíso - apenas frutos gigantescos.

[Esboço]

Quadro - vôo do Príncipe: Vamos, assim deve ser, pelo caminho da Morte até à morada da felicidade?*

As vozes estão sublinhadas.

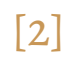

Pode fazer-se um chão colorido?

Figurinos: devem simplesmente ser feitos e a única excepção deverá acontecer no primeiro acto.

[Esboço com a seguinte anotação do autor:]

em cores claras e simples sem refinamento dos tons

[Cores] complexas e ricas só em concordância com a música

uma grande trombeta
3 A adaptação cénica do conto $O$ Jardim do Paraíso de Hans Christian Andersen foi para o pintor Wassily Kandinsky uma forma de envolvimento activo num projecto estético-dramatúrgico mais alargado, que visava renovar a criação teatral na viragem do século. Segundo notas diarísticas de Gabriele Münter, a companheira do pintor durante a fase de Munique, Kandinsky teria concebido os cenários para a encenação do referido conto, ao longo do Inverno de 1908-1909. Data deste período o aprofundamento da amizade e a colaboração entre o pintor e o músico e compositor russo Thomas von Hartmann, que terá composto a partitura para este projecto cénico. 
I Príncipe e Árabe com serpente, cavalo do arauto.

II Acto. Asa Mágica. Uma nuvem eleva-se. Frutos cintilam do interior para fora. Agrupar as pessoas ao longo da escada, à direita e à esquerda, e em relação à árvore à direita e ao edifício à esquerda, isto é, as mesmas cores, mas depois da entrada do Arlequim, o movimento e as cores misturam-se.

IV Preto-branco. As flores brancas adquirem cores sumptuosas.

[Primeiro fragmento]

\section{ASA MÁGICA}

No início: palco vazio, a seguir entrada dos actores e do público por detrás.

W. PRIMEIRO ACTO: Danças sobre o pódio e descida da escada: Árabe com serpente muito grande - linha direita com uma espiral, Mágico [esboço] Arlequim [esboço]

Atleta com gordas pernas cor-de-rosa em fato de baile, vestido (?) com conchas. Mágico, todo de preto com uma barba esverdeada, pequenas lâmpadas vermelhas sobre o barrete, por cima das vestes a Via Láctea.

[esboço]

Árabe, todo de branco com um rosto muito escuro.

Preto colorido com rosto preto.

Arlequim - amarelo com fato vermelho.

Estão agarrados uns aos outros e só se separam para dançar, depois voltam a enlaçar-se.

Mágico, Árabe, Arlequim, Atleta, pódio elevado, conjunto de pessoas olhando para cima

\section{[1 VERSO]}

Velha de verde vivo com um lenço vermelho vivo na cabeça. Antes do aparecimento do arauto faz-se escuro; quando se ouvem trombetas atrás do palco, aparece uma coloração amarela que se acentua com a entrada das trombetas. Ela transforma-se num tom avermelhado durante a leitura da ordem e com a palavra "morte" - num instante tudo desaparece. 
[Segundo fragmento]

\section{[2]}

\section{ASA MÁGICA}

Primeiro Acto: Depois das danças da multidão faz-se de repente silêncio e escuro, e, depois de uma pausa, ouvem-se ao longe sons de trombetas acompanhadas por uma luz amarela que vai aumentando devagar (ambas se incendeiam em conjunto). De ambos os lados saem dois trompetistas e ouve-se o martelar dos seus tacões altos em madeira.

ff [fortissimo] das trombetas e da luz amarela. Pausa. Martelar dos sapatos. A luz amarela baixa e dela aparece um vermelhão que aumenta com a chegada do arauto. Enquanto ele lê, a luz torna-se progressivamente num vermelho claro e quando se ouve a palavra "morte" todas as cores desaparecem, o movimento suspende-se e

\section{[2 VERSO]}

tudo fica cinzento opaco. Depois, de repente, um movimento em voo como se fosse vento. Pausa e afastamento do arauto e reaparecimento das cores. 
DAFNE E CLOÉ ${ }^{4}$

$1908-1909$

[1]

JARDIM DO PARAÍSO

\section{Dafne e Cloé ${ }^{5}$}

Prelúdio: quadro, figuras que se deslocam devagar umas a seguir às outras, o coro com os mesmos movimentos. ${ }^{6}$

[esboço]

Quadro: barco preto

[esboço]

Quadro: mar vermelho, de uma onda à direita, a crescer de repente até ao tecto, aparece uma silhueta negra e indistinta e agarra-se ao barco.

Imediatamente a seguir escuro.

[esboço]

\section{[1 VERSO]}

Prólogo

Quadro I: flores, borboletas

Jogos, danças. Apresentação de sacrifícios. Uma fonte.

[?] - Disputa sobre a beleza. Um beijo.

Quadro II: Rapto de Cloé

Quadro III: Desespero de Dafne

Quadro IV: Tempestade

Quadro V: Cenário do Quadro I, regresso de Cloé.

Carícias e insatisfação. Um velho. Aparecimento da grega e

acordar da paixão.

Quadro VI: Cenário do Quadro I. Os pretendentes. Dança de Cloé que se afasta dos pretendentes em direcção a Dafne. Os pais. Consentimento do casamento. Quadro VII: Banquete, danças, narração sobre Siringe e apresentação de Dafne e Cloé. Leito nupcial.
4 A colaboração entre Wassily Kandinsky e o compositor Thomas von Hartmann alarga-se, no início do ano de 1908, ao bailarino e coreógrafo Alexander Sacharoff. É no salão literário de Marianne von Werefkin e Alexej Jawlensky, em Munique, que Kandinsky e Sacharoff se apercebem do interesse comum por peças de cerâmica grega antiga com representações de cenas de dança.

Esta parceria artística alimentou em Kandinsky a ideia de adaptar ao palco o romance pastoril Dafne e Cloé de Longos que o pintor conhecia a partir de uma versão em russo da autoria de D. Merežkovskij, publicada em São Petersburgo em 1904.

De acordo com o testemunho de Gabriele Münter, Kandinsky escreveu os textos, concebeu o cenário e até uma maqueta cénica, sem que, contudo, tivesse havido qualquer representação.

O bailarino Serge Diaghilev obteve, com o seu agrupamento Les Ballets Russes, um êxito assinalável ao apresentar em Paris, em 1912, uma versão dançada do referido romance com coreografia de Michel Fokin, música de Maurice Ravel e cenografia e figurinos de Léon Bakst.

5 O texto original desta Composição para Palco foi escrito em russo com algumas palavras em alemão, tendo o autor procedido à tradução do mesmo para língua alemã.

Trata-se de um conjunto de folhas soltas manuscritas, contendo diversos fragmentos posteriormente ordenados para corresponderem a um desenvolvimento de uma acção.

6 Estas duas linhas encontram-se em alemão no original.

7 Nome de uma Hamadríade da Arcádia que foi amada por Pã. O deus perseguiu-a nas margens do rio Ládon e quando estava quase a alcançá-la, 
Pequeno pátio interior.

\section{[2]}

\section{Dafne e Cloé}

A cortina não desce entre os quadros, mas no fim de cada quadro há escuridão até ao preto total, por vezes de forma progressiva (Quadro I), outras vezes de forma repentina (II, IV, V e VII), às vezes de forma rápida mas não de repente (III, VI).

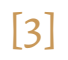

Prólogo: Lentamente como num sonho o Coro avança até à boca de cena. Quando os últimos tiverem quase abandonado o palco, ouve-se (atrás dos bastidores) o canto deles do prólogo.

Por cada nome pronunciado aparece a respectiva personagem que, devagar como num sonho, passa em redor pela boca de cena, olhando para diante de si. Quando, no sonho, as ninfas cantam, elas tornam-se visíveis (projecção) no plano anterior do palco à esquerda da árvore. Ao serem ditas as palavras "rapaz com setas", vê-se à direita da árvore Amor.

Quando termina o canto imediatamente o Quadro I.

\section{[4]}

Prólogo. Coro ${ }^{8}$

Muitas vezes as pessoas são mais rudes e cruéis do que

[os animais.

Muitas vezes também, grosseiramente envergonhado pelo

[exemplo dos animais,

Um homem, de repente, em vez do Mal pratica uma boa [acção.

Um qualquer pastor de cabras viu, entre os ramos de um arbusto, um recém-nascido deitado e quieto, vestido de púrpura

[com uma fivela doirada.

Uma teta cheia de uma cabra estava mesmo por cima dele.

A teta cheia, agarrada pelas mãos da criança alimentava-a

$$
\text { [como um peito. }
$$

Lamon, o pastor, pensou logo em roubar a púrpura e a fivela, ela transformou-se numa corça. Como o vento tivesse começado a soprar, Pã lembrou-se de juntar com cera canas de vários tamanhos. Foi assim que nasceu a flauta de Pã ou Siringe, em honra da ninfa fugidia. Outras versões do mito referem que em vez de corça, Siringe teria tomado a forma de uma cana, transformando-se desse modo no mesmo instrumento musical. (cf.

Grimal, 1992: 421)

8 Este subtítulo aparece escrito na vertical da margem esquerda do documento manuscrito. 
Quando a boa acção da cabra o envergonhou.

Assim, pegou na criancinha e deu-a à sua esposa Myrtale.

As mulheres são melhores do que os homens, pois Myrtale

$$
\text { [pegou logo na criança }
$$

Com ternura e ao enjeitadinho foi dado o nome de Dafne.

A criança foi alimentada por aquela mesma boa cabra.

Dois anos mais tarde, aconteceu o mesmo a Dryas, o

[pastor de ovelhas.

Numa gruta encontrou um recém-nascido com uma fita

[dourada nos cabelos

Com um pano de algodão bordado a oiro.

Uma ovelha alimentava-o com a sua teta.

\section{[4 VERSO]}

Nape, a mulher de Dryas, também ficou com a criança.

Assim, de modo rústico, puseram à menina o nome de Cloé.

Em sonhos também as ninfas apareceram a Dryas e a Lamon.

A um adolescente verdadeiramente belo, portador de asas, [flechas e

$\operatorname{arco}$

As ninfas entregaram Dafne e Cloé.

O adolescente tocou Dafne com uma flecha

E ordenou-lhe que guardasse e apascentasse as cabras.

E a Cloé, as ovelhas. Isto aconteceu ao fim de quinze [Primaveras.

Por vontade das Ninfas Dafne tornou-se pastor e Cloé [pastora.

\section{Ninfas no sonho de Dafne}

Dafne não nos envies repreensões: estamos cheias de

[cuidados com Cloé.

Pã, a quem tu não ofereceste flores nem orações,

Atendeu as nossas súplicas para salvar Cloé do cativeiro.

Com a sua força tremenda, Pã levantou-se contra os terríveis

Metimneus $^{9}$

Amanhã já Cloé inesperadamente regressa outra vez para ti

O deus do Amor consumará tudo isto, tudo o que tem de ser

[consumado.
9 Habitantes da cidade de Metimna, na costa norte da ilha de Lesbos, e raptores de Cloé. 
Quadro II. No palco, paisagem; lentamente uma nuvem borrascosa azul eleva-se e rasga-se aqui e acolá, de modo a ver-se o céu amarelo. Mais tarde, um barco pret avança da esquerda e devagar ocupa todo o palco anterior. No momento em que pára, eleva-se imediatamente na proa um guerreiro, segurando nas mãos levantadas uma lança e um escudo. Ele olha para cima e em frente. Nesta mesma pose elevam-se também, um a seguir ao outro, outros guerreiros. Fazem descer uma escada muito íngreme e deixam-se escorregar por ela até ao chão. Dançam entre rochedos, procuram qualquer coisa e saem um a seguir ao outro para os bastidores. Depois de uma pausa, ouve-se a sua corrida rápida, o tilintar das armas. Eles entram no palco, um a seguir ao outro. Um traz nos braços Cloé, ela agarra-se com uma mão ao pescoço dele e a outra mão fica estendida. Eles sobem depressa para o barco e tiram a escada. Neste momento faz-se imediatamente escuro.

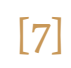

Quadro III. Cenário como no primeiro quadro. No palco está Dafne em desespero. Procura, corre, atira-se inesperadamente de um lado para o outro. Em breve os seus cabelos esvoaçam de um lado para o outro, em breve tombam-lhe sobre o rosto e ele afasta-os para trás com as mãos. Por fim ele deixa-se cair sobre os joelhos diante da estátua da Ninfa, ora, põe-se de repente em pé, de um salto, agita os punhos como que a maldizer as Ninfas.

De repente as suas forças diminuem e ele ajoelha-se, cobrindo o rosto com as mãos. Depois procura de novo Cloé. Como não a encontra, abraça a estátua e chora. Depois de ter acabado de chorar, dirige-se para a esquerda com passos fatigados, seca as lágrimas, senta-se junto à fonte e adormece. Devagar surgem por cima ${ }^{10} \mathrm{da}$ fonte as Ninfas “iguais às estátuas”, como que criadas a partir da própria espuma. O coro canta Pã. As Ninfas tornam-se cada vez mais precisas. No final do coro, escurecimento rápido.

\section{[8]}

\section{Pã durante a tempestade ${ }^{11}$}

Quem vos acordou, seres de coração desvairado, para [actos desvairados?

Injuriando a Deus, ó sacrílegos, ofendestes aquela que
11 Este fragmento pertence ao quadro IV e encontra-se no verso 1 do manuscrito, em conjunto com um desenho a lápis em papel de linhas, da autoria de Wassily Kandinsky. 
[tanto amamos,

Os rebanhos sagrados sob nosso cuidado vós atingistes, Ao deus do amor vós vos opusestes, raptores de Cloé, As ninfas, vós não respeitastes, nem a mim,

[tanto intimidastes Pã!

Que todos os dilúvios vos engulam, que atirados aos peixes

[eles vos comam,

Se não trouxerdes já Cloé de volta para a margem.

[Mal Cloé pise terra

(se me quiserdes escutar), então vos enviarei ventos

[bonançosos

A vossa viagem por mar verá então o fim na casa

[dos regressados.

(calmo e cinzento)

Quadro IV. Durante a dança de Dafne e Cloé (Siringe), passa ao fundo, por cima do mar verde, um barco colorido com velas vermelho vivo. No princípio há rapazes e raparigas ajoujados sob o peso de imponentes cestos de uvas (um com uvas pretas, um outro com uvas vermelho-rosa, um terceiro com uvas brancas, um quarto com uvas amarelas).

Os cestos serão colocados no proscénio, segundo a ordem das cores. 


\section{PREFÁCIO}

$1908-1909$

\section{Prefácio}

Estas peças de teatro foram designadas de composições cénicas, pois não se enquadram em nenhuma das formas habituais e são compostas por elementos que requerem impreterivelmente o palco como meio de representação. Estes elementos são 1) sonoridade musical, 2) sonoridade da cor, 3) movimento (em sentido restrito). Estes elementos serão utilizados de forma tão despojada quanto possível, i. e., a sua eficácia específica torna-se no meio de produzir a impressão sobre o espectador. Cada sonoridade,

\section{$[2]$}

Cada cor, cada movimento tem um valor interior. Eles agem directamente, mesmo se utilizados em separado. A combinação dos diferentes meios tem como resultado um efeito complexo que oferece duas possibilidades:

I) ou se combinam meios que agem ao mesmo tempo - então aumenta a força do efeito, ou

2) a combinação de diferentes meios em acção desencadeia uma complicação do sentimento.

Quando se pega, por exemplo, em sentimentos simples e grosseiros, então o sentimento de alegria pode, por ex., ser expresso através do som, da cor e do movimento, e esta utilização simultânea de meios conduz ao desenvolvimento da eficácia (origina, digamos, um fortissimo do sentimento); ou um elemento provoca alegria e os outros dois provocam tristeza. Produz-se uma complicação do sentimento: a alegria é bastante

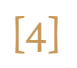

perturbada, neutralizada pelo sentimento de tristeza. A sonoridade interior que daí resulta, assemelhar-se-á à sonoridade física de um vaso rachado. Estes sentimentos segundos \{impuros\}, sem uma sonoridade clara, são antes de mais sentimentos do homem moderno: o materialismo decadente e aquilo que há-de vir são as 2 sonoridades que afinam de igual modo a nossa alma. 
O princípio da combinação dos

meios inumerados é o seguinte: o elemento que pode imediatamente provocar com mais intensidade o efeito desejado será utilizado neste caso como elemento principal. Os outros subordinar-se-ão a este, passam para segundo plano ou desaparecem pura e simplesmente. Assim, a cor desempenha por vezes o papel principal, mais tarde a tonalidade musical ou o movimento. Este é apenas o princípio que só

é de considerar como tal. As composições partiram apenas do sentimento puro e nenhuma violência foi exercida sobre o sentimento puro. \{Isso\} Assim terá de ser e assim será sempre também, onde se tenha como objectivo da arte apenas o efeito sobre o sentimento, sobre a alma. Estes sentimentos que têm de nascer através da acção, não podem ser definidos com exactidão através de palavras: eles são de uma substância delicada e

não se podem cobrir com a palavra material.

Já a designação sentimento é demasiado material para estas vibrações da alma, demasiado precisa e, por isso, restritiva.

Toda a vida interior da alma, que existe meio adormecida no homem, é o princípio e o fim das obras subsequentes. O abaixo-assinado é o autor da parte literária e pictórica das

composições. A música < para orquestra> que não pôde aqui ser publicada foi concebida para orquestra pelo compositor Th.[omas] v. [on] H. [artmann]. \{As três partes foram trabalhadas em conjunto como afinação homogénea.\} \{Ambos os autores\} A unidade de todas as três partes \{essa\} foi elaborada a partir da estreita colaboração dos dois autores. 


\section{A. GIGANTES}

$1908-1909$
12 O minucioso manuscrito de G Münter dá a entender que se trata de música em registos "altos".]

\section{"Gigantes"}

Fundo a[zul]. Canto (mecânico) atrás - Barco verde estridente com gigantes amarelos. Ombros altos, om [bros] baixos / Movimentos lentos uns em direcção aos outros e para os lados. Música. Gigantes levantam-se, sentam-se <atrás>. Pássaros vermelhos com rostos humanos. Canto dos gigantes (pianíssimo). No barco, música em registo al[to $]^{12}$, mais tarde misturada atrás com canto [?] e palco pre[to]. O canto prolonga-se por muito tempo.

"As fl. [ores] da poesia

estão espalhadas no mundo

Junta-as numa coroa eterna

Na pri.[são] serás livre

No deserto não estarás só.”

Ao m.[esmo] tempo peq.[enas] figuras indistintas [esboço]

Sobre a colina, olhando para a fren.[te]. Pessoas voam colina acima. Os Gigantes murmuram algo entre si.

[esboço]

Música \{eles desapar.[ecem] a pouco e pouco\} e cada vez mais estridente. Mais tarde procissão estridente. $\mathrm{E}[\mathrm{sc}] \mathrm{u}[\mathrm{r}] \mathrm{o}$ e ermita. Música.

Céu cinzento com grande nuvem pre.[ta]. Sino.

[Esboço com pormenores das cores: ] vermelho - verde-amarelado - branco - pre.[to] - pre.[to]]

Música. - Um gigante ocupa o palco todo como uma cruz em fundo azul. Os braços erguem-se e crescem. Amarelo claro. Rosto branco indistinto. 
Composição para palco I.

"Gigantes"

(À direita e à esquerda do espectador)

I. Cortina levantada e no palco, ao fundo, o cume largo de uma colina verde com algumas poucas flores singelas. Bem atrás, fundo bastante azul, profundo, liso e baço. Em breve soa a música em registos agudos. De repente, ela torna-se grave e a moldura de f[un]do escurece até ficar negra. Por detrás do palco ouve-se um grande coro mecânico, desajeitado, sonante, sem palavras (sem sentimento). A seguir a música pára. 5 gigantes amarelo estridentes são puxados para o palco da dir. para a esq., sem barulho (se possível sobre rodas).

Os gigantes (ombros altos e baixos) mexem muito devagar as cabeças, uns em direcção aos outros e para o lado, fazem movimentos simples com os braços. Mantêm-se de pé em frente da colina. Passado algum tempo, música. Um pouco depois soa o canto baixo dos gigantes (piano), sem palavras, e os gigantes dirigem-se muito devagar para a ribalta.

Figuras vermelhas semelhantes a pássaros com rostos parecidos com os dos humanos voam pelo ar (o que se reflecte na música). Quanto mais os gigantes se aproximam do proscénio, mais obscuros eles ficam, devido às cortinas de gaze azul. O seu canto soa como o do coro desajeitado no princípio. O palco torna-se

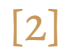

o palco torna-se ${ }^{13}$ azul opaco (cortinas). A orquestra começa a lutar com o coro (durante longo tempo).

II. A pouco e pouco desaparecem as cortinas azuis. No fundo do palco uma colina verde estridente com $<$ muitas $>$ flores singelas. (Maiores do que em I) 
Fundo violeta. Da esquerda surgem pessoas em trajes claros com muitas flores e dizem:

"As flores da poesia estão espalhadas pelo mundo

"Junta-as numa coroa eterna

"No deserto não estarás só

"Na prisão estarás livre."

(Isto é para ser dito em conjunto e de forma repetida,

\section{$\left[2^{\mathrm{a}}\right]$}

dizem-no uns aos outros ou para si mesmos, cada voz por si: contralto, baixo, soprano. Pouco depois entra a orquestra, na qual se torna perceptível uma ideia. A seguir surgem, da dir. para a esq., pequenas figuras indistintas que empurram lentamente qualquer coisa colina acima, olhando em frente (elas são cinzentas esverdeadas). As pessoas reparam nelas, ficam imóveis, correm para a ribalta, olham para si próprias e uma escuridão repentina envolve o palco.

III. Entre 2 grandes rochedos castanho-avermelhados estão os 2 gigantes de pé a segredar (os mesmos que em I), fundo preto. Desde o início, a música torna-se cada vez mais estridente. Da esq. vêm

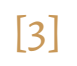

muitas pessoas com trajes diferentes (curtos, compridos, justos, largos, etc.). Primeiro vêm sobretudo de cinzento, depois especial [mente] de preto, de branco; por fim às cores. Elas repartem-se de maneira diferente pelo palco: algumas sentam-se em grupos apertados, outras ficam afastadas umas das outras, enquanto outras estão de pé, em grupo ou sozinhas. As pessoas olham em direcções diferentes, para cima e para baixo. Elas alteram pouco estas posições. À esq., próximo do fundo, alguém faz movimentos rápidos e simples com os braços e as pernas. A pouco e pouco todos olham para esse alguém. De repente, esse alguém senta-se, pouco depois estica um braço e movimenta [-o], mexe a mão lentamente em direcção à cabeça. Todas as cabeças se esticam na sua direcção ele. O seu movimento

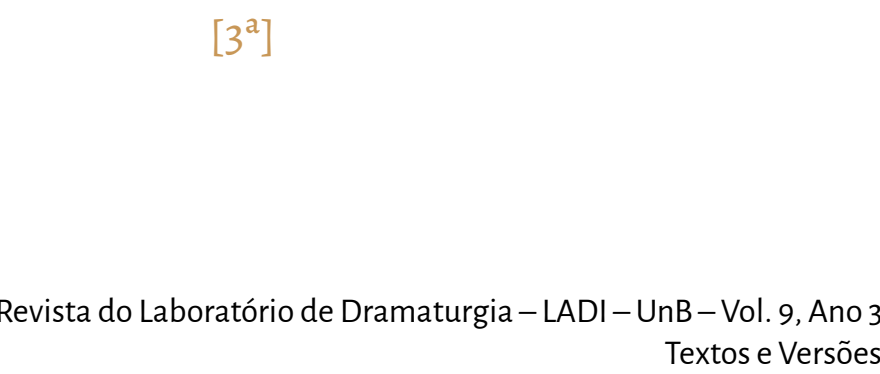


acaba com o cotovelo a apoiar-se no joelho e a cabeça deitada na palma da mão. Da música ecoam cores isoladas. Em conformidade com isto várias pessoas se levantam devagar, de maneira solene ou precipitada e olham para cima ou para o lado. Elas voltam a sentar-se ou ficam de pé. Em diferentes cantos tem início um movimento, as pessoas abandonam os seus lugares e dirigem-se rapida ou lentamente para outros grupos. Aqueles que estão de pé sozinhos aproximam-se uns dos outros e formam pequenos grupos de 2, 3 pessoas. Grandes grupos desagregam-se. A pouco e pouco todos se levantam e iniciam um movimento arrítmico. Grupos inteiros vão para trás dos bastidores e voltam outra vez. Mas a pouco e pouco o número de pessoas aumenta.

\section{[4]}

O preto-acinzentado e o branco desaparecem, o colorido fica. Em diferentes pontos acontece dança, que se torna cada vez mais vigorosa e se expande a toda a volta. Movimentos enérgicos de aproximação e de afastamento, corridas, saltos, quedas no chão. Pessoas isoladas executam movimentos enérgicos apenas com os braços, outras com as pernas, algumas delas articulam os dois movimentos entre si. Aqui e ali há movimentos de grupo (nos quais, por vezes, é executado um movimento por todo um grupo). " Por fim, o amontoado de pessoas executa movimentos bruscos de todos os tipos. Música a condizer. No momento da máxima agitação, escuridão e silêncio repentinos. Atrás ficam apenas visíveis os gigantes

que também serão progressivamente

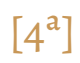

engolidos pela escuridão.

IV. Visível: céu amarelo-acinzentado, nuvem vermelho-negra à direita, em cima. Debaixo da nuvem, em primeiro plano, mesmo junto aos bastidores, um homem preto com barba branca, braço esquerdo junto ao peito, o direito esticado para o lado. No fundo à esquerda, uma casinha branca com uma torrezinha (sino), uma chaminé comprida, estreita e com fumo vermelho. Junto à casinha, de joelhos e curvado, um garoto preto toca a corda do sino. Durante todo o tempo ouve-se música não em uníssono com o sino. A pouco e pouco tudo fica completamente escuro.
* [Este acrescentamento, escrito à mão, (a lápis) por Kandinsky, encontrava-se na página [ $3^{\mathrm{a}}$ verso]:] No centro agrupam-se figuras vestidas de vermelho. Elas \{estão de pé\} formam um círculo e têm os rostos inclinados para o peito. Batem com os pés e cantam a compasso uma melodia monótona, sem palavras, que soa sempre cada vez mais alto. Ao mesmo tempo batem com os pés cada vez mais vigorosamente. As outras pessoas colocam-se à dir. e à esq destas, juntam-se à melodia e ao batimento de pés. 
V. O primeiro fundo azul baço (sem margem preta) No meio do palco, um gigante amarelo-claro (rosto branco e indistinto, grandes olhos pretos). Ele levanta ambos os

\section{[5]}

braços, perpendicularmente ao corpo, e assim cresce. Quando \{ele\} $\}^{14}$ consegue colocar os braços em cruz (com as costas das mãos para cima), faz-se escuridão repentina. A música é expressiva e acompanha a acção.

Fim.
14 [A palavra "ele" foi primeiro riscada e depois novamente inserida.] 


\author{
C. O SOM AMARELO, 1912 \\ Impressão especial, excerto do Almanaque \\ O Cavaleiro Azul com notas à mão e acrescentamentos de Kandinsky
}
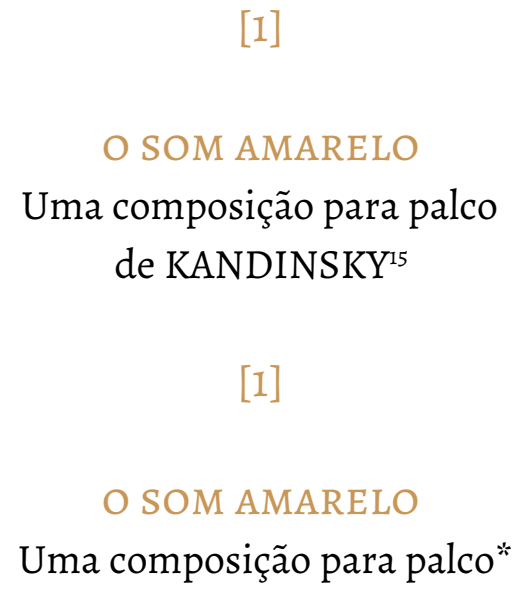

Participantes:

Cinco gigantes

Seres indistintos

Tenor (por detrás do palco)

Uma criança

Um homem

Pessoas em traje solto

Pessoas em maillots

Coro (por detrás do palco)
* A parte musical esteve a cargo de Thomas von Hartmann.

15 [O exemplar que se encontra nos Arquivos Kandinsky, completado pelo autor, possui a inscrição seguinte:] " $A$ vida é realmente bela... mas as pessoas são demasiado estúpidas/ Prof. Dr. N. v. Hildebrandt, Stuttgart, 28 de Junho de 1924." ( Boissel, 1998: 60.)

\section{$[1]$}

\section{INTRODUÇÃO}

Alguns vagos acordes na orquestra.

Pano de boca.

No palco um crepúsculo azul claro que começa por ser esbranquiçado e só depois se vai tornando num azul-escuro intenso. Algum tempo depois, torna-se visível no meio do palco uma pequena luz que, com o acentuar da cor, vai ficando mais clara. Algum tempo depois,

Música de orquestra. Pausa.

Atrás do palco ouve-se um coro que tem de ser organizado de modo a não se reconhecer 
a origem do canto. Devem ouvir-se principalmente as vozes dos baixos. $O$ canto é uniforme, sem temperamento, com paragens que são assinaladas por reticências.

\section{[6]}

Primeirovozes g r aves:

"Sonhos pétreos... $<3$ " $>$ E rochedos falantes... $<4$ ">

Leivas com enigmas de perguntas saturantes... $<5$ " $>$

Do movimento do céu... <3" > E fusão... $<2$ " > das

Pedras... <4">

Crescendo invisível em direcção às alturas... $<5$ "> um bastião..." <2">

Voz e s a gudas:

"Lágrimas e risos... <3" > Orações por entre imprecações... $<3$ " $>$

Unidos o prazer e as mais negras batalhas."

Todas as vozes:

"Luzes das trevas no... $<4$ " > mais ensolarado... $<5$ " > dia

(extinguindo-se depressa e de repente).

"Sombra de um brilho estridente na mais escura noite!!"

A luz desaparece. De repente, faz-se escuro. Pausa mais prolongada. $<15$ " $>$ A seguir entra a orquestra...

\section{$\mathbf{1}^{\circ}$ QUADRO}

< Pausa 5"> (À direita e à esquerda do espectador.)

Neste quadro o palco tem de estar a grande profundidade. Lá atrás, uma vasta colina verde. Por detrás da colina, um telão liso, baço, azul, de cor razoavelmente escura.

Em breve $<5$ " $>$ começa a música, primeiro em registo agudo, $<10$ " $>$ passando, imediatamente a seguir e de forma rápida, para registos graves. Ao mesmo tempo o fundo torna-se azul-escuro (acompanhando as mudanças musicais) e adquire largas margens pretas (como num quadro). Por detrás do palco ouve-se um coro sem palavras que canta sem emoção, bastante seco e mecânico. <60"> Quando o coro acaba de cantar, pausa geral: ausência de movimento, ausência de som. $<10$ " $>$ A seguir escuro. $<5$ " $>$ 
A seguir a mesma cena será iluminada. Da direita para a esquerda, cinco gigantes de um amarelo estridente (tão grandes quanto possível) serão empurrados para cena (como se estivessem suspensos mesmo por cima do solo).

Eles ficam de pé, bem lá atrás, ao lado uns dos outros - uns com os ombros levantados, outros com eles descaídos, com rostos estranhamente amarelos e indistintos. $\langle 5-10$ ">

$\mathrm{M}$ u i t o devagar eles voltam as cabeças uns para os outros e executam movimentos simples com os braços. <30">

A música torna-se mais acentuada.

Logo a seguir, o canto $\mathrm{m}$ u i t o grave e sem palavras dos gigantes torna-se audível (pianissimo), e eles aproximam-se $\mathrm{m}$ u i t o devagar da ribalta... <15"> Da esquerda para a direita voam a toda a pressa seres vermelhos indistintos que, d e c e r t o m od o, fazem lembrar pássaros com grandes cabeças, vagamente aparentados com seres humanos. Este vôo reflecte-se na música.

[Esboço]

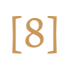

Os gigantes continuam a cantar e sempre cada vez mais baixo, tornando-se por isso cada vez mais indistintos. A colina ao fundo vai aumentando devagar e torna-se cada vez mais clara. Por fim, fica branca. O céu torna-se completamente preto. $<20$ ">

Por detrás do palco começa a ouvir-se o mesmo coro seco. $<30$ "> Os gigantes deixam de se ouvir.

O proscénio torna-se azul e cada vez mais opaco.

A orquestra luta com o coro e vence-0. $\left\langle 5^{\prime}\right\rangle$

Uma nebulosidade espessa e azul torna todo o palco invisível.

\section{$\mathbf{2}^{\circ}$ QUADRO}

$<$ Pausa 10">

A nebulosidade azul vai a pouco e pouco dando lugar à luz que é de um branco totalmente estridente. $<20$ " $>$ No palco, ao fundo, uma colina tão grande quanto possível, de um verde estridente.

O fundo é violeta, bastante claro. 
A música é estridente e impetuosa, com repetições constantes de lás e de sis e de sis e de lás bemol. Estes sons individualizados acabam por ser engolidos pela forte impetuosidade da música. <5-10’> De repente, faz-se silêncio total. Pausa. $<10$ "> O lá e o si voltam a gemer lastimosos, mas com determinação e estridência. Isto dura bastante tempo. $<10$ " $>$ Depois novamente uma pausa. $<5$ " $>$

Nesse momento, o fundo torna-se de repente castanho sujo. A colina torna-se verde sujo. E mesmo no centro da colina forma-se uma mancha negra indefinida que ora se evidencia or desaparece. $<15$ " $>$ Sempre que se altera a nitidez, a luz branca estridente torna-se, de modo descontínuo, mais cinzenta. À esquerda sobre a colina vê-se de repente uma enorme flor amarela. Ela parece-se vagamente com uma espécie de enorme pepino curvo e vai-se tornando cada vez mais estridente. A haste é comprida e fina. $<10$ " $>$ Do meio do caule cresce apenas uma folha estreita, espinhosa e que está inclinada obliquamente. Longa pausa. $<25$ " $>$

\section{[12]}

Pouco depois, em c o m p l e t o s i lê n c i o, a flor baloiça muito devagar da direita para a esquerda. A seguir também a folha se move mas não em simultâneo. <10"> Pouco depois ainda, baloiçam ambas em ritmo desencontrado. $<5$ " > Voltam então a baloiçar, cada uma por si $\langle 10$ " $\rangle$, embora o movimento da flor seja acompanhado pelo som muito fraco de um si, e o movimento da folha, acompanhado por um lá muito profundo. Depois voltam ambas a baloiçar ao mesmo tempo e os dois sons ouvem-se em consonância. <10"> A flor estremece violentamente e fica sem se mexer. As duas notas continuam a ouvir-se na música. Ao mesmo tempo aparecem, vindas da esquerda, muitas

pessoas de vestes soltas, compridas e estridentes (uma está toda de azul, a segunda de vermelho, a terceira de verde, etc., só falta o amarelo). As pessoas trazem na mão flores brancas muito grandes que se parecem com a flor sobre a colina... As pessoas mantêm-se o mais possível perto umas das outras, passam junto à colina e ficam do lado direito do palco, muito apertadas umas contra as outras. Elas falam com vozes misturadas e recitam:

"As flores cobrem tudo, cobrem tudo, cobrem tudo.

Fecha os olhos! Fecha os olhos!

Nós contemplamos. Nós contemplamos.

Cobrimos de inocência a concepção.

Abre os olhos! Abre os olhos!

Já lá vai. Já lá vai." <30"> 
Primeiro, todas juntas e como que em êxtase, dizem isto (com muita clareza). Depois repetem tudo individualmente, uma a seguir à outra, e projectando à distância as vozes de contralto, baixo e soprano. Ao dizerem "Abre os olhos, abre os olhos", ouve-se um si. Ao dizerem "Já lá vai, já lá vai”, ouve-se um lá. De vez em quando, a voz torna-se rouca. De vez em quando, alguém grita como se estivesse possesso. De vez em quando, a voz torna-se nasal, ora lenta, ora furiosamente rápida." No primeiro caso, todo o palco

Fica de repente iluminado por uma luz vermelha mate que o torna indistinto. No segundo caso, alterna a total escuridão com uma luz azul estridente. No terceiro, tudo se torna de repente acinzentado (desaparecem todas as cores!) Só a flor amarela brilha ainda com mais intensidade! <60">

A pouco e pouco a orquestra ataca e abafa as vozes. A música torna-se agitada, dá saltos de fortissimo para pianissimo. A luz torna-se um pouco mais clara e as cores das pessoas reconhecem-se de forma indistinta. <60"> Da direita para a esquerda deslocam-se muito devagar, colina acima, umas figurinhas muito pequenas, indistintas, de uma cor verde acinzentada de tonalidade vaga. Elas olham à sua volta. No momento em que a primeira figura se torna visível, a flor amarela baloiça como se tivesse espasmos. Depois desaparece de repente. Com a mesma rapidez, todas as flores brancas se tornam amarelas.

As pessoas deslocam-se devagar, como num sonho, em direcção ao proscénio e vão-se afastando cada vez mais umas das outras.

\section{[13]}

A música baixa e volta a ouvir-se o mesmo recitativo. ": Em breve as pessoas ficam de pé, como que em êxtase, e voltam-se de costas. Apercebem-se, de repente, das pequenas figurinhas que continuam a passar por cima da colina numa sequência interminável. As pessoas voltam-se, dão uns passos rápidos em direcção ao proscénio, voltam a ficar imóveis, viram-se de novo e ficam impassíveis, como que ligafas umas às outras. ${ }^{* * *}<10$ " $>$ Por fim atiram fora as flores que parecem impregnadas de sangue e, libertando-se com violência da imobilidade, correm coladas umas às outras em direcção ao proscénio. Frequentemente olham em redor. ${ }^{* * * *}$ De repente faz-se escuro.

" Meia frase pronunciada em conjunto; o final da frase de uma voz soa muito indistinto.

** Estes movimentos têm de ser executados como se fosse uma ordem.

*:*: Estes movimentos não precisam de ir a compasso.
* Luz: qd. a voz é nasal-vermelho / qd. ela é lenta-azul cl. [aro] / qd. é rápida - cinzento. [Acrescentado à mão por

Kandinsky na margem esquerda]

(Boissel, 1998: 76.)

$\because$ Meia frase pronunciada em conjunto; o final da frase de uma voz soa muito indistinto.

: Estes movimentos têm de ser executados como se fosse uma ordem

*::*: Estes movimentos não precisam de ir a compasso 
16 [a. I. é a abreviatura da expressão latina ad libitum - à escolha.]

\section{$3^{\circ}$ QUADRO}

$<$ Pausa 30" $><$ Cores sujas. $>$

Plano anterior do palco: dois grandes rochedos de um vermelho acastanhado, um pontiagudo, o outro arredondado e maior do que o primeiro. Entre os rochedos estão de pé os gigantes (do $1^{\circ}$ quadro) e sussurram uns aos outros qualquer coisa que não se ouve. Em breve sussurram aos pares, em breve todas as cabeças se aproximam umas das outras. O corpo permanece imóvel. Em mutações rápidas surgem de todos os lados feixes de luz de cores estridentes (azul, violeta, verde, mudando diversas vezes).

<20-30"> Depois todos os feixes de luz convergem em direcção ao centro, sendo aí misturados. Tudo permanece imóvel. Os gigantes estão quase a deixarem de se ver. De repente todas as cores desaparecem. Durante um momento fica tudo preto. Depois derrama-se no palco uma luz amarela mate que, a pouco e pouco, se vai tornando cada vez mais intensa, até todo o palco ficar amarelo-limão estridente. " Com o aumento da luz a música baixa e torna-se cada vez mais sombria (este movimento faz lembrar um caracol a comprimir-se na casca). <a.l. $5>^{16}$ Durante estes dois movimentos não deve ver-se no palco nada a não ser luz: nenhuns objectos. A luz atingiu a sua intensidade máxima, a música é completamente langorosa. Os gigantes voltam a ser perceptíveis, estão imóveis e olham em frente. Os rochedos não voltam a aparecer. No palco estão apenas os gigantes: agora estão mais separados uns dos outros e tornaram-se maiores. O fundo e o chão são pretos. Longa pausa. $<20$ " > De repente ouve-se atrás do palco uma voz estridente e assustada de tenor que grita muito depressa palavras completamente incompreensíveis (ouve-se muitas vezes lá: p. ex.. Kalasimunafakola!). Pausa. $<5$ ”> Durante um momento faz-se escuro. $\langle 3$ " $>$

\section{$[15]$}

\section{$4^{\circ}$ QUADRO}

<Não há qualquer música neste quadro!>

À esquerda, no palco, um pequeno edifício inclinado (semelhante a uma ermida muito simples) sem porta nem janela. Ao lado do edifício (a par-
* [Este acrescentamento do autor (margem esquerda) não se refere a uma passagem específica do texto:)] O amarelo domina tudo. Tudo - se funde. Também a música deve ser melodiosa. Deve terminar com instrum.[ento(s)] de madeira - em tonalidade baixa e nasalada (oboé). 
tir do telhado) uma torrezinha estreita, inclinada, com um pequeno sino rachado. Pendente do sino uma corda. Uma criança pequena, de camisinha branca e sentada no chão (virada para o espectador), puxa devagar e compassadamente a parte inferior da corda. <30">< uma batidela cada 3"> À direita, no mesmo alinhamento, um homem muito gordo está de pé, todo vestido de preto. O rosto todo branco, muito indistinto. A ermida é de um vermelho sujo. A torre, azul estridente. $O$ sino é de lata. Fundo cinzento por igual, liso. O homem de preto está de pé, de pernas abertas e com as mãos postas nas ancas. O homem (ordenando muito alto, com bonita voz):

"Caluda!!"

A criança larga a corda. Faz-se escuro.
* É óbvio que a música tem igualmente de se repetir.

\section{[16]}

\section{$5^{\circ}$ QUADRO}

O palco enche-se a pouco e pouco de uma luz vermelha fria que progressivamente $<60$ " $>$ se vai tornando mais intensa, ao mesmo tempo que passa devagar a amarelo. <60"> Nesse momento, os gigantes ao fundo tornam-se visíveis (como no $3^{\circ}$ quadro). Também lá se encontram os mesmos rochedos.

Os gigantes voltam a sussurrar (como no $3^{\circ}$ quadro). Nessa altura, quando as cabeças deles voltam a estar juntas, ouve-se atrás do palco o mesmo grito, mas muito rápido e breve. Durante um momento faz-se escuro. $<3$ "> 0 mesmo processo repete-se uma vez mais." Depois de ter clareado (luz branca sem sombras), os gigantes voltam a sussurrar, ao mesmo tempo que executam ligeiros movimentos com as mãos (estes movimentos têm de ser diferentes, embora subtis). De vez em quando, um deles espreguiça-se (este movimento também não deve passar de uma alusão) e põe a cabeça um pouco de lado, olhando para o espectador. Por duas vezes todos os gigantes deixam cair os braços de repente, tornam-se um pouco maiores e olham imperturbáveis para o espectador. Depois os corpos deles são alvo de uma espécie de convulsão (semelhante à da flor amarela) e põem-se de novo a sussurrar, afastando de vez em quando os braços ligeiramente

como se se queixassem. <a.l. não mais de 3 a 5'> A música vai-se tornando a pouco e pouco mais estridente. Os gigantes permanecem quietos. Da esquerda surgem muitas pessoas com maillots de diversas cores. Os cabelos estão cobertos com a cor do respectivo maillot. Tal como os rostos. (As pesssoas parecem bonecos articulados). Primeiro aparecem pessoas cinzentas, depois 
pretas, brancas e finalmente às cores. Os movimentos são diversos em cada grupo: um caminha depressa e em frente; o outro devagar, com esforço; o terceiro dá de vez em quando saltos divertidos; o quarto está permanentemente a olhar em torno de si; o quinto avança com passos teatrais e festivos e traz os braços cruzados; o sexto caminha em bicos de pés com a palama da mão para cima, etc.. <3 a 5'>

Todos se espalham de modo distinto pelo palco: uns sentam-se em pequenos grupos fechados, outros sentam-se sozinhos. Outros estão de pé em grupo, enquanto outros estão isolados. Toda a distribuição não tem que ser nem "bonita", nem muito ordenada. Também n ã o d e ve s e r uma t o t a l confusão. As pessoas olham para diferentes lados, algumas estão com as cabeças levantadas, outras com elas baixas ou completamente viradas para o chão. Como que atingidas por um abatimento, raramente mudam de postura. A luz mantém-se sempre branca. A música muda muitas vezes de andamento, mas de vez em quando também enfraquece. Exactamente num destes momentos, uma pessoa de branco, à esquerda (bem ao fundo), executa movimentos indefinidos mas muito rápidos, ora com os braços, ora com as pernas. De vez em quando mantêm um movimento durante mais tempo e conservam-se na respectiva posição por alguns momentos. É como se fosse uma espécie de dança. Só que o ritmo também se altera com frequência, daí que muitas vezes vá ao compasso da música e outras não. (Este processo simples tem de ser desenvolvido com particular cuidado, para que o que vem a seguir exerça um efeito expressivo e surpreendente). As outras pessoas começam progressivamente a olhar para a pessoa de branco. Algumas esticam os pescoços. Por fim, olham todas para ela. Esta dança, porém, termina muito de repente: a pessoa de branco senta-se, estica um braço como se se tratasse de uma preparação festiva, e dobrando-o devagar pelo cotovelo, leva-o à cabeça. A tensão geral torna-se particularmente expressiva. A pessoa de branco, porém, bate com o cotovelo no joelho e põe a cabeça na palma da mão. $<$ Música - dança popular divertida.> Por momentos faz-se escuro. $<3$ "> Depois vêem-se os mesmos grupos e posições. Muitos dos grupos são iluminados de cima, com maior ou menor itensidade, com diversas cores: sobre um grande grupo que está sentado incide um vermelho intenso; sobre um grande grupo que está de pé cai um azul desmaiado, etc.. A luz amarela estridente (à excepção dos gigantes que aparecem agora com particular nitidez) concentra-se apenas sobre a pessoa de branco que está sentada. De repente, desaparecem todas as cores (os gigantes continuam amarelos) e uma luz branca crepuscular enche o palco. $<20$ " > Cores isoladas começam a dialogar na orquestra. Para lhes corresponder, levantam-se de diferentes lugares figuras isoladas: rápi- 
das, bruscas, festivas, lentas, e começam a olhar para cima. Algumas ficam de pé. Outras voltam a sentar-se. $\langle 5$ " $>$ Depois todas são tocadas por um abatimento e tudo se imobiliza. $\langle 5$ " $>$

\section{[18]}

Os gigantes sussurram. Mas também eles permanecem agora imóveis e direitos, enquanto no fundo do palco se torna audível o coro seco que se faz ouvir apenas por pouco tempo. $<10$ " $>$

Depois ouvem-se de novo na orquestra cores isoladas. <a.l. não mais de 60"> Um feixe vermelho de luz surge por cima dos rochedos e estes estremecem. $\langle 3$ "> Com esta iluminação estremecem alternadamente os gigantes. $\langle 3$ ">

Em algumas extremidades é perceptível um movimento. <30">

$\mathrm{Na}$ orquestra repetem-se várias vezes si e lá: separadamente, soando em conjunto, ora muito fortes, ora quase inaudíveis."*

Diversas pessoas abandonam os seus lugares e dirigem-se para outros grupos, ora depressa, ora devagar. Os que estão sozinhos formam pequenos grupos de duas ou três pessoas ou enquadram-se em grupos maiores. Os grandes grupos desintegram-se. Algumas pessoas põem-se a correr para fora do palco, olhando sempre à volta. Entre elas desaparecem todas as pessoas de preto, cinzento e branco. No palco acabam por ficar apenas as pessoas coloridas. $<60$ a $80^{\prime \prime}><$ Os feixes de luz desaparecem. $>$

A pouco e pouco generaliza-se um movimento arrítmico. Na orquestra impera a confusão. $O$ grito estridente do $3^{\circ}$ quadro torna-se audível. Os gigantes tremem. Diversos focos de luz varrem o palco cruzando-se. <30">

Grupos inteiros abandonam o palco. Tem origem uma dança generalizada: começa em lugares diversos, espalha-se a pouco e pouco e arrasta todas as pessoas. Corridas, saltos, corridas como aproximação e dispersão, quedas. De pé, uma quantidade de pessoas move apenas os braços com rapidez, outras apenas as pernas, apenas a cabeça, apenas o tronco. Outras combinam todos estes movimentos. À s v e z e s são movimentos de grupo. Grupos inteiros fazem à s v e z e s um e o mesmo movimento. <30">

No momento em que se atinge a maior confusão na orquestra, nos movimentos e na iluminação, faz-se d e r e p e n t e escuro e silêncio. Só ao fundo do palco continuam a ser visíveis os gigantes amarelos que lentamente vão sendo engolidos pela escuridão. Parece que os gigantes se apagam como candeeiros, ou seja, no meio da completa escuridão a luz relampeja algumas vezes. $<40$ ">
* Entre as p. 16 e 17 o autor enfiou uma follha solta onde anotou. Saltos na música: "bonita" - repentina polifonia grosseira (brutal, angulosa), depois notas triunfantes, a seguirtristeza até às lágrimas, etc. a.l. música desaparecendo, [?] não mais de 3 a 5'/ diz respeito à p.17. (Boissel, 1998: 82.)

** [Esta anotação do autor encontra-se em pé de página:] Alternadamente, durante períodos de tempo irregulares, feixes de luz caem sobre diferentes grupos: vermelho, vermelho, vermelho, azul, vermelho, azul, azul, etc. - por vezes dois ou três em conjunto. Como abelhas sobre as flores, a sugarem-Ihes o pólen. (Boissel, 1998: 84.) 
* [Para o $6^{\circ}$ quadro, o autor tinha igualmente sugerido, em relação ao Almanaque do Cavaleiro Azul, correcções que o editor não aceitou. Estas correcções manuscritas encontram-se numa folha solta Arquivos Kandinsky, Paris). Elas dizem respeito aos três últimos parágrafos, cf. Fig. 6, p. 85.]

(Boissel, 1998: 86)

*** [Sobre uma folha solta, acrescentada ao texto (cf. Fig. 6), coberta de notas na página da frente e verso, 0 autor comenta o fim desta composição para palco como se segue:]

17 Inicialmente o autor tinha escolhido a ordem inversa: «supra-terrestre e não terrestre.»
\{Fundo e chão pretos\}

Verticalmente cai sobre ele um feixe de luz amarelo limão de intensidade média. [Fim do parágrafo seguinte.]

O feixe de luz amarelo torna-se cada vez mais intenso e mais abrangente, englobando também os braços que se elevam. O gigante dissolve-se quase completamente nesta luz. É preciso que nesta altura o movimento, a cor e a música caminhem de facto em paralelo e construam um final calmo. Muito amplo!

\section{$[20]$}

< Final - ao contrário de toda a acção - muito ampla! O amarelo eleva os braços e a música deve ser calma, solene, um pouco supra-sensível (aquilo que aqui se alcança não é de natureza terrestre, mas supra-terrestre ${ }^{17}$, como um processo natural - como se fosse uma nuvem que evolui lentamente, de forma determinada, fria, objectiva e ampla (largo! largo!), não no sentido de um qualquer estado de espírito, mas no sentido de uma acção objectiva). A m[ú] s[i]ca [?] é semelhante à da introdução, imprecisa, dilacerada, com interrupções, cheia de respirações (como uma libertação - esforço natural caótico, tensão - só Deus sabe como se desfaz a tensão!)

\section{[20 VERSO]}

Depois vem o canto sem temperamento (o contrário da libertação) - como um vento de força média atravessando a floresta: ALGUÉM fala aqui objectivamente, i. e., sem sentimento pessoal em relação a um facto estabelecido.> 
VOZES

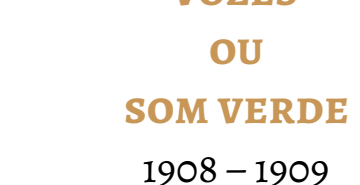

[1]

Composição para palco II

\section{"VOZES"}

* no cimo da encosta, verde um pouco quente, em baixo, a tender para azul muito forte, vertente rosa.

$\because$ azul \{verde\} claro, contorno espesso, azul acinzentado esuro, parte inferior azul profundo.

[Estas duas notas suplementares encontram-se na p. [1 verso]]

*:*: A música só será referida quando for o elemento principal.

(À direita e à esquerda, da perspectiva do espectador.)

Ouvem-se alguns acordes. Pausa.

O pano sobe.

No palco, na esquerda baixa, 3 figuras de cócoras, ao lado umas das outras. À direita, quase no limite, uma figura muito direita, de pé, com o rosto voltado para os bastidores. Três figuras sentadas, da esquerda para a direita, estão vestidas de vermelho frio (com um pouco de azul), verde frio e azul bastante claro. Rostos: verde escuro frio, verde claro a tender muito para amarelo, verde frio muito claro < (as mãos laranja) $>$. A figura de pé tem um traje preto, rosto

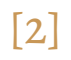

e mãos amarelo escuro. Os trajes são muito amplos, informes, cobrem o cabelo e vão até ao chão. Na esquerda alta, uma colina gigante*, à direita montanhas longínquas**, céu às manchas [?], cinzento, chão azul esverdeado. Tudo quase irreconhecível, imperceptível, em contrapartida as cores devem falar com intensidade. Após um curto espaço de tempo, música**** Ela pára e nesse mesmo momento entra da direita homem com um traje com manchas coloridas. Ele mantém-se muito direito e caminha devagar pelo palco, por detrás das figuras (em $2^{\circ}$ plano), olhando para a sua frente. Pouco depois, ainda uma maior imperceptibilidade no palco ao fundo

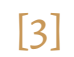

e um barulho, como se o céu caísse sobre a terra. Logo a seguir, o homem que caminha põe-se a falar:

"À minha volta uma vaga neblina. Dentro de mim o sossego do silêncio."

Música. O homem sai. 
A figura á direita vira a cabeça devagar em direcção às 3 figuras sentadas e levanta o braço esquerdo co a mão rígida, um pouco inclinada (palma da mão para cima).

As 3 figuras sentadas põem-se de pé $\{e\}$, voltam as cabeças umas para as outras e saem pela direita. De tempos a tempos dão olhadelas para diferentes

\section{[4]}

lados.

Ao mesmo tempo, todo o palco \{sempre o fundo do palco\} escurece. $<$ A figura à frente mantém-se indistinta mas visível.> Música.

\section{$2^{\circ}$ QUADRO}

Depois do fundo do palco ter permanecido durante algum tempo mergulhado em completa escuridão, de repente, aparece atrás um muro <amarelo> com um portão baixo muito colorido. Por detrás do muro vê-se um conjunto desordenado de cúpulas singulares coloridas. A figura < preta $>$ à frente desaparece de repente nesse mesmo instante. O portão abre-se para fora e uma torrente de pessoas (hoens, mulheres, crianças) sai a correr e enche o palco.

Todo este quadro, ao contrário do anterior, deve manter-se muito colorido, claro e estridente. Os trajes dos homens são cafetãs compridos, que estão fechados ou abertos e deixam ver camisas compridas. Os cabelos são longos e em alguns dos homens vão até aos ombros. Rostos coloridos em consonância pictórica com traje e cabelo. O mesmo em relação às mulheres, que trazem uma espécie de sarafã como vestido, também de cor uniforme ou com motivos muito simples (quadrados ou círculos, etc.). As crianças têm camisas soltas ou apanhadas por um cinto.

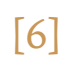

Através de agrupamentos* sucessivos forma-se ao fundo uma massa animada por um vago e inquietante movimento. As pessoas querem aceder ao centro deste movimento. Vêem-se braços levantados, às vezes $<$ com $>$ os punhos cerrados. A multidão é atirada de um lado para o outro do palco, como um barco no mar.
*As pessoas caminham sem destino em diferentes velocidades e direcções. Aqui e ali uma espécie de conversação ou narração. 
$\grave{A}$ frente $\{$ formam-se\} diversos grupos e figuras, que nada têm a ver com os outros nem com a multidão ao fundo. À frente um homem muito velho com bastão $\left(\mathrm{n}^{\circ} 1\right)$. Perto dele, uma mulher sentada com uma criança (2); atrás dela 2 raparigas e um rapaz. Mais adiante, um jovem músico a tocar (4).

Ele toca para uma jovem rapariga (5) que aí se encontra com ar sonhador e talvez nada oiça; na frente dela, um rapazinho (6) que, interessado, observa o músico a tocar. Mais adiante, à direita, uma mulher sentada, <muito > gor$\mathrm{da}$, vestida de forma colorida. Ligeiramente atrás dela, um par de namorados abraçados. Do outro lado do velho, 2 rapazinhos (9) de mãos dadas (um vestido de vermelho com rosto vermelho de feições grosseiras e barrete pontiagudo à banda; o outro <com ><rosto magro $>$ muito pálido, traje branco com grandes pintas azuis. \{Um pouco\} atrás deles à esquerda, um mendigo sentado, ligeiramente curvado, torto - segurando muletas com a mão esquerda, na direita uma tijela para as esmolas. Por detrás dele 6 guerreiros com trajes amarelos <estridentes>, ornamentados

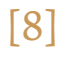

com grandes quadrados vermelhos Mais à frente 2 garotos (10), um de costas viradas para o espectador, olhando o outro, que está pálido, tem grandes olhos $<$ rasgados> e olha em frente, com as mãos contra o peito. Atrás deles, um grande homem preto com uma fina barba branca comprida. Perto dele um pequeno homem rubicundo com as mãos apoiadas nas ancas. No canto esquerdo, uma velha mulher sentada. Atrás dela, uma mulher jovem, vestida de verde-claro, com um véu comprido e o rosto inclinado para cima. (Música contínua).

Depois dos grupos se terem formado, todas [?] as figuras permanecem imóveis, durante muito tempo, à boca de cena.

Atrás, a multidão

é impelida, a pouco e pouco, para fora de cena, pela direita. Ao mesmo tempo, vindo da direita, onde se encontra o par de namorados, ouve-se um monólogo de amor cantado por uma voz grave de mulher:

"Eterno será o passado

E a cura ao dilacerado 
Chegará. E a seguir

O seco irá florir.

Sem obrigação e sem nome

Se une a verdadeira semente

E em fusão se transfigura...

Onde nasce? Onde acaba?
18 No texto original o autor usa o substantivo "Maßen" (medidas), embora a palavra que faz sentido neste contexto seja o substantivo "Massen" (massas). Os organizadores do volume mencionado na nota 1 alertam para a confusão do autor. Ver op. cit., p. 96.

Durante este canto, por detrás dos grupos, corre a toda a pressa, da esquerda para a direita, palco fora, um número de figuras muito brancas com rostos brancos dificilmente reconhecíveis. Nessa altura a música pára por momentos. Logo a seguir, uma figura feminina completamente verde desloca-se muito devagar, da direita para a esquerda à boca de cena, sempre a olhar para os espectadores. O seu rosto é de um verde muito pálido com grandes olhos <escuros $>$ sem movimento. Ouve-se da esquerda, onde o mendigo está sentado, uma voz lastimosa (masculina, aguda, um pouco nasal), que

\section{[11]}

canta num andamento lento e arrastado:

"Sou paralítico. Sem me apoiar

Eu não posso andar.

Antes de nascido

Tinha a força perdido.

Eu não vislumbro o sol a cintilar

Como poderei a luz tocar?

Antes de nascido

$O$ rosto perdido.

Apodreço em desabrigo

Para as massas ${ }^{18}$ eu vivo

Antes de nascidos

Já estamos perdidos!"

A pouco e pouco todo o palco 
escurece completamente. Só a figura verde é visível. Música. A figura continua a andar, mas torna-se imperceptível e sai. Escuridão completa. A música continua. 
PRETO E BRANCO

$1908-1909$

A. [Sem título; primeiras anotações para Preto e Branco 1908 - 1909]

\section{[79]}

[Sem título]

I. [esboço]

um movimento de nuvens $\left\{[\text { ?] }\}^{19}\right.$

II. [esboço]

Deslocamento de preto e branco. ${ }^{20}$ Muitos deslocam-se (de modo ritmado). Depois, vindos da esquerda, páram em posição de marcha. Voltam-se lentamente, os braços pendentes afastam-se do corpo. Ao fundo caminham mulheres (de branco) da esquerda para a direita. A mesma cena paradas. (Um som muito breve de corneta). Silêncio, apenas movimento de nuvens.

\section{[80]}

O preto cresce. Adormecimento. Voz.

[III. 2 esboços sem qualquer texto]

IV. [esboço com indicações de cores: limão - amarelado - branco - cinábrio + verde - esverdeado - pret.[o]

Em cima de um cavalo branco (malhado) ${ }^{21}$ cavalga um cavaleiro preto. Mais tarde, ${ }^{22}$ vento nas árvores. Desaparecimento das nuvens. (Barulho de cascos). Chegam pessoas que se sentam de perfil.

[Esboço] O céu torna-se branco azulado.

\section{Preto $[e s b o c ̧ o]^{23}$}

Faz-se escuro. As pess.[oas] põem-se de pé. De repente transportam fachos brancos e afastam-se com estranhos movimentos.
19 No manuscrito a palavra riscada poderá ser "nuvens"]

20 [No manuscrito a palavra "branco" foi riscada e posteriormente reescrita.]

21 [A ideia é a de um cavalo russo.]

22 ["Mais tarde" foi riscado e depois novamente introduzido.]

23 [Este final do $4^{\circ}$ quadro está escrito na p. 81 a seguir a uma receita de culinária.] (Boissel, 1998: 100.) 
$1908-1909$

A. Composição para palco III - Preto e Branco

Composição para palco III

("Preto e branco").

I. <"Branco".> Música. Sobe o pano. No fundo do palco uma figura sentada, de formas arredondadas, " branca, grande, (a partir dos ombros a parte superior desaparece na teia do palco). Ela tem sobre os joelhos uma espécie de lenço branco que cai em grandes pregas sobre o chão. Lá bem ao fundo, montanhas azuis (de um azul muito profundo com manchas avermelhadas e amareladas sobre a direita). Em baixo o céu verde-sujo eleva-se à esquerda em azul, à direita em rosa. Nuvens oblongas, brancas e comprimidas passam enviuzadas sobre o céu, da esquerda para a direita. O chão é branco-róseo. À esquerda, à boca de cena, sobre uma pedra cinzenta, um homem vestido de preto mantém ambos os braços no colo.

\section{[2]}

Muito tempo depois, ele levanta o braço esquerdo para o alto, mantém-no esticado por cima da cabeça, enquanto o braço direito cai em direcção ao chão. Cortina. A música continua.

II. \{Movimento de\} "Preto" \{e branco\}. \{Azul-esverdeado\} Céu verde-azulado com 2 nuvens (em cima à direita, maiores, algodoadas, quase brancas; em baixo à esquerda, pequenas, muito claras, branco-amareladas).

Grande montanha preta, ao fundo, <um pouco $>$ \{parecida com $\} \mathrm{u}<\mathrm{m}>$ monstro deitado sobre todo o palco. Muito em breve, homens vestidos de preto (jovens, velhos com rostos esverdeados, róseos, etc.) deslocam-se devagar no palco, da esquerda para a direita, em direcção à boca de cena, apoiando-se em paus (pretos). Quando tiverem passado entre 10 a 12, pequena pausa; a seguir prossegue o movimento. Depois de entre 6 a 8 já estarem em cena, vem a correr da esquerda um jovem todo vestido de branco com um rosto de um amarelo muito quente e cabelos 
muito loiros. Aproximando-se bastante dos outros, ele estica de repente o em cena.

braço esquerdo, com a palma da mão para cima e para a frente, o braço direito estendido um pouco para trás. Tudo se imobiliza. <Atrás dos homens $>$ deslocam-se, da esquerda para a direita, mulheres vestidas de branco com rostos escuros ou claros, os braços caídos ao longo do corpo e de costas direitas. Depois de 10 a 12 terem passado, pausa, mais 6 a 8, " da direita entra uma mulher vestida de preto a andar depressa que, tal como acima se menciona, interrompe o movimento. Por um momento tudo se imobiliza. A seguir todas as pessoas se movimentam muito devagar em direcção ao espectador. Pausa. Elas levantam os braços com os cotovelos ligeiramente flectidos e as mãos abertas e estendidas (as costas das mãos para cima) até à altura das ancas, as cabeças inclinadas.

\section{[4]}

Ouve-se por um momento um subtil e acentuado som de corneta. Os braços elevam-se completamente, as cabeças pendem para trás. Silêncio. Apenas as nuvens se deslocam devagar para cima e desaparecem. Os braços tornam a cair, as pessoas sucumbem e sentam-se em lugares diversos. Só o homem branco e a mulher preta ficam de pé, imóveis (aliás, eles nunca tomam parte nesses movimentos e permanecem muito direitos, de perfil, com as mãos $<$ bem > cruzadas sobre o peito). A montanha pret.[a] eleva-se primeiro devagar e depois cada vez mais depressa. Assim que ela tenha praticamente coberto todo o fundo, começa a ouvir-se por trás do palco uma voz gutural muito aguda que anuncia qualquer coisa indistinta, nervosa e incómoda.

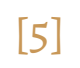

Escuridão progressiva, na qual também a voz se dilui [?].

III. <"Preto e Branco">. Música (com duração mais longa). Cortina. Atrás 2 montanhas gigantes que deixam apenas entrever uma estreita faixa verde clara de céu (a montanha da esquerda é de um azul muito sombrio a tender para o preto, com manchas pretas espalhadas irregularmente, a da direita tem <umas quantas $>$ listras vermelhas aqui e acolá). À boca de cena, uma colina preta (não muito alta) que evoca um pouco um\{caixão\} ataúde. Sobre ela $<$ deitada $>$ de prefil uma figura de mulher $\{$ branca\}, grande, in- 
distinta, $5 \mathrm{x}$ maior do que o tamanho natural, coberta com um tecido branco < ( a cabeça também) > e até aos pés que, ao chegar ao chão, continua por aí fora. Após um momento, surgem da esquerda muitas pessoas vestidas de cores várias, com os rostos na mesma tonalidade do fato. Coladas umas às outras, elas caminham como

uma comprida fita colorida em direcção ao fundo < do palco $>$ e depois até à boca de cena (como numa procissão), comunicando entre si através de movimentos dos braços.

Por fim, elas formam uma longa fila no fundo à esquerda <e cantam>:

"Medo profundo, intuições alegres

"Gélidos cumes e trilhos vacilantes.

"Véu preto como a morte. Ventos em sanha.

"Silêncio branco. Despedaça e enlaça!

"Laços em pedaços!

"À vista lugares remotos!

"Pedaços enlaçados

$$
\text { Despedaça e enlaça! }
$$

"O preto dominado!

$$
\text { "Despedaça e enlaça!" }
$$

(Aquando de "Pedaços enlaçados", as pessoas deslocam-se devagar para a direita - postura erecta, ligeiramente a des

cair para a frente, os pescoços direitos, os braços pendentes). A pouco e pouco faz-se escuro. No palco vazio, durante um certo tempo, luz difusa, cinzenta. Depois, a pouco e pouco, escuridão total.

IV. Música forte. Cortina. Céu amarelo-alaranjado com nuvens brancas, arredondadas e alongadas. Três grandes árvores altas com formas arredondadas e enviuzadas, com ramos pretos (dos quais 2 têm manchas coloridas - arredondadas - como se fossem frutos). À esquerda, no horizonte, faixas pretas estreitas. Em cima de um cavalo branco (cavalo russo-rodado), da direita para a esquerda, cavalga devagar um cavaleiro vestido de preto (grande barulho dos cascos). Um vento agita as árvores, as nuvens elevam-se e tornam-se cada vez mais densas. \{Atrás\} Da direita surgem figuras 
cobertas com véus (o primeiro verde-claro quente, o segundo verde-claro frio, o terceiro verde-claro quente, etc.). Assim que elas tiverem alcançado $2 / 3 \mathrm{da}$ cena \{ajoelham-se\} sentam-se de perfil com os joelhos flectidos, de viés, umas atrás das outras. Depois de um curto momento, ouve-se atrás do palco um forte cavalgar. O céu vai-se tornando completamente branco, algumas faixas pretas formam-se bem no cimo. Escurece < bastante>. As figuras levantam-se de repente e de repente têm nas mãos fachos a arder. Afastam-se precipitadamente, sempre a olhar para todos os lados. As ásvores voltam a balançar. Um pássaro \{azul\} verde eleva-se nos ares e desaparece no alto, tornando-se cada vez mais azul e por fim completamente azul. 


\section{Composição para palvo IV}

[Figura preta]

\section{$\mathbf{1}^{\circ}$ QUADRO}

No palco (6) a 8 figuras vestidas com diversos fatos coloridos. Estão imóveis. \{A lua crescente (laranja, e a tender para o vermelho-zarcão em baixo e à d.) desce lentamente em direcção oblíqua e para a direita\} As vozes têm diferentes timbres que se adequam entre si.

Figura 5-Pleno... Pleno... (voz mezzo)

"7- "Profundidade" (voz de baixo)

\section{Pausa}

"8 - "Nenhum som" - (voz sem timbre, mezzo)

Pausa

“4 - Tendência para os agudos (voz de mulher, alto)

Figura 6-"Tenso tremor" (contralto)

"1 - "Vida salutar" (Tenor)

"2 - "e ardor profundo" (baixo)

(A lua crescente laranja e a tender para o vermelho em baixo à

d. descendo lentamente num movimento \{oblíquo\} para a direita.

"8 - "Sem som, sem ruído"

"2- Palavra oculta

Todos < (lentamente e sem esforçar a voz) > - Quem a construiu?

(Escuro)

$\mathbf{2}^{\circ}$ QUADRO. Chão branco, fundo completamente liso de um vermelho estridente (cinábrio). 2 grandes árvores pretas de cada um dos lados à frente

[Esboço]

Duas figuras vestidas de branco (homem e mulher), ambas com longos cabelos pretos e com rostos muito rosados, vão da direita para a esquerda ao fun- 
do \{de mãos dadas\} muito juntinhos e com os braços caídos ao longo do corpo. Antes de começarem a andar, mantêm-se de pé, virados para os espectadores, muito direitos e próximos um do outro.

Ela A eterna fusão [?] no coração e no peito

A eterna alegria e o prazer sonante

Ele $\mathrm{E}$ a eterna esperança no céu e na terra

E a eterna aspiração ao ser e ao devir

Da direita aparece um cortejo < de seres azuis claros> que transportam uma liteira branca, colocada no meio do palco. As duas figuras brancas sobem para a liteira.

O cortejo põe-se em movimento e sai.

$<$ Exactanebte $>$ atrás dele caminha

\section{[4]}

uma silhueta ne.[gra] \{violeta\} com uma grande [?] cabeça esverdeada pálida sobre um pescoço estreito e comprido. De repente ela mostra o seu braço longo (dentro de uma manga estreita) e estende-o por cima da liteira. O céu torna-se vermelho-púrpura. As árvores inclinam as copas para o chão. O cortejo sai.

$3^{\mathbf{0}}$ QUADRO. Decoração do $1^{\circ}$ quadro. As mesmas figuras mas todas reunidas em pequenos grupos e muito juntas, ao fundo à esquerda. Elas cantam:... oh - oh - oh... Ao fundo, por cima da água azul segue um barco preto de onde se eleva muito direita a silhueta negra, que volta a estender o braço. Ela passa lentamente e desaparece

entre o primeiro e o segundo rochedo à esquerda. As figuras voltam-se para ela e \{tentam\} durante algum tempo acompanhar o seu trajecto. Depois elas sentam-se como no $1^{\circ}$ quadro e dizem (em voz baixa):

Figura 5 - Pleno... Pleno...

"7-Profundidade...

"8-"Nenhum som

(Escuro)

$4^{\circ}$ QUADRO. Sobre um céu violeta um gigantesco arco-iris sobre todo o fundo. 
[Esboço]

Por cima dos rochedos, de um azul como lápis-lazúli, um castelo com 2 cúpulas douradas. Tiras de mar verde-esmeralda. Uma árvore vermelha com grandes flores cor-de-rosa à direita e, um amarelo <claro> sobre flores brancas à esquerda. Um grande número de homens

e mulheres, todos vestidos de cor-de-rosa, entram pela direita a correr e de mãos dadas. Eles oram, puxam as mãos uns dos outros, beijam-se, atiram para trás a cabeça como sob o efeito de uma grande felicidade, formam uma roda e dançam de forma selvagem e divertida com gestos vivos, saltos. A seguir, a roda desfaz-se, as pessoas formam 2 grupos que se perseguem mutuamente para voltarem a dançar. Por fim, já muito cansados, caem no chão aos pares (1 homem e 1 mulher), formando grupos desiguais, mas regularmente repartidos sobre todo o palco. Cantam. Da \{esq.\} da dir. aparecem, a caminhar sobre as pontas dos pés, de cabeça levantada à procura de qualquer coisa, e de dedo estendido diante do rosto, uma figura

toda coberta de azul com rosto branco. Ela acaba por parar e acena com o dedo. Logo a seguir aparece, vinda da esq., uma figura semelhante, também ela com o dedo levantado. Ela avança um pouco no palco, pára, vira-se e acena também com o dedo. De novo da esq. aparece ainda uma outra figura parecida. A figura que se encontra à direita e de pé vira-se e acena com o dedo. Chegam ainda mais duas figuras da dir. Todas se aproximam umas das outras, depois viram-se e voltam a acenar. A seguir, aparecem dos dois lados, pequenos grupos de 2 ou 3 dessas figuras. Por fim, elas formam uma <linha $>$ que ocupa todo o fundo do palco.O arco-íris desaparece. Uma grande nuvem

\section{[8]}

de tempestade redonda e branca-acinzentada eleva-se ao fundo sobre o mar. As árvores estremecemOuve-se por detrás do palco o canto: $20 \mathrm{~h}$ - oh - oh". Os seres de cor-de-rosa viram-se com medo, vêem as mulheres azuis e ficam hipnotizados a olhar para elas. As mulheres azuis movem-se lentamente em direcção à ribalta. O céu torna-se preto, a nuvem completamente branca. Bem 
ao fundo, como por cima da água, aparece a figura negra. Um enorme grito se escapa dos seres cor-de-rosa. As figuras azuis continuam sempre a avançar e inclinam-se agora <um pouco> para a frente.

Escuro.

Por detrás do palco o coro: "Nenhum som, nenhum som".

\section{$5^{\circ}$ QUADRO}

O céu está laranja, os grandes pinheiros informes são azuis. À esquerda debaixo de um dos pinheiros senta-se de perfil um rapazinho de 8 a 10 anos, com uma camisa verde clara $<$ comprida $>$, de pernas estendidas. A princípio está imóvel, depois levanta a cabeça e suspira. Um pouco mais tarde, pega numa das pequenas vara que estão junto dele, numa faca, e põe-se a tirar a casca à vara. Passado algum \{tempo\}, ouve-se um cuco. $O$ rapaz procura-o com os olhos, mas não o vê, volta a suspirar e canta:

Queridas varinhas vou fazer de vocês qualquer coisa boa Farei de vocês belas coisas.

Ouve-se o cuco.

O rapaz volta a segui-lo com os olhos e repete em pensamento

Farei de vocês belas coisas.

Queridas varinhas vou fazer de vocês qualquer coisa

boa.

Vem da dir. uma menina, com cerca de 8 anos de idade, ela vê o rapaz, pára, põe um dedo na boca e olha. $O$ rapaz, pouco amável, \{diz\}:

"O que queres tu daqui?"

A rapariga:

"Ando à procura de morangos. Olha! (Ela pega num raminho de morangos de dentro do cestinho que traz no braço, e

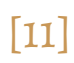

mostra ao rapaz). 
Ele: Sim... dá cá!

Ela: (dirige-se a ele com a mão estendida) Come lá, come lá! Eras tu que estavas a cantar?

Ele: Sim, era eu. (Ele pega no raminho de morangos)

Ela: Come lá, come lá! O que estás tu aqui a fazer?

Ele: (orgulhoso) Estou a construir qualquer coisa de muito belo. Estás a ver, com estas varinhas? Estou a construir um castelo.

Ela: (ri) Que engraçado! Um castelo! Mas não se pode construir um castelo com estas va.[rinhas].

Ele: E porque não?

Ela: $\mathrm{Tu}$ \{tonto\}! Elas são demasiado pequenas.

Ele: (convencido) Mas eu ainda vou cortar muitas e muitas varinhas. Oh, muitíssimas!

Ela: Quem irá viver no castelo?

Ele: Eu... (olha para ela) e tu.

Ela: (batendo as palmas) Oh, claro, eu também quero viver no castelo!

Ele: (levanta-se) Tu queres ser minha mulher? Queres?

Ela: Sim, quero (Ela estende os lábios para o beijar)

Ele: (Beija-a e mantém os morangos cuidadosamente na mão estendida).

O cuco canta.

Ela: Oh, o cuco!

De detrás de um pinheiro aparece o homem pret.[o]. Ele dá alguns passos de mansinho $r$ levanta o braço. As crianças vêem-no, \{e\}, fazem um movimento de recuo e apertam-se uma contra a outra. O homem acena-lhes com o dedo. Elas olham para ele durante muito tempo, daõ as mãos uma à outra e dirigem-se com um passo hesitante na direcção do homem, que continua a acenar-lhes. Ouve-se o cuco a gritar ainda por $2 \mathrm{X}$, brevemente. As crianças procuram-no com olhos e avançam apesar de tudo na direcção do homem.

Escuro

FIGURA PRETA

\section{Composição para palvo IV}




\section{Epílogo (sem música)}

Sobre a direita no fundo do palco, uma colina: abrupta à esquerda, suavemente inclinada à direita, desaparecendo progressivamente nos bastidores. $<\mathrm{Os}$ bast.[idores] formam uma simples moldura cinzenta também em cima>. A colina é azul. Sobre o seu cume alongado, um comprido banco branco <com um suave encosto branco. $>$ Por detrás da colina $(\mathrm{e}<\mathrm{um}$ pouco $>$ também sobre $<\mathrm{a}$ sua > direita) uma montanha cónica mas irregular - branca com <grandes> manchas pretas irregulares. Sobre a esquerda e bem ao fundo, duas árvores estreitas, pretas, tombando uma sobre a outra, com finos ramos de um amarelo estridente. <Os contornos das árvores são pura e simplesmente uniformes.> Eles alcançam toda a altura (?) do palco. No banco estão sentadas duas fi

guras : vermelho estridente <também os rostos $>$ e rosa estridente. \{Por detrás do palco (e da esquerda e da direita\} Dos bastidores do lado direito vai até ao cume da colina uma escada branca. <Os degraus podem ser visto de perfil.> Um certo número de figuras, também elas vermelhas e cor-de-rosa, sobem <lentamente e umas atrás das outras> os degraus dessa escada. Elas sentam-se no banco, muito apertadas umas contra as outras. A última figura, porém, parece-se com um velho com uma longa barba branca e fina. Esta figura é completamente preta. Todos olham para ela fixamente. Passado um bocado, uma dessas figuras começa de repente a rir de forma <estridente e agudas.

Pausa... Uma outra boceja..., <mas sem viva.[cidade] $>$

Pausa...

Vindo da esquerda, atravessa o palco

um grande número de freiras, apressadas e coladas umas às outras, <um pouco inclinadas para a frente $>\mathrm{e}<$ todas a olhar nessa direcção $>$. De repente, a última <antes de sair de cena> vira-se para os espectadores com o seu rosto branco uns olhinhos pretos muito pequeninos. As freiras são pequenas e <avançam bastante em direcção à ribalta. A fig. [ura] atrás é grande.

Pausa... 
$\{$ Também\} chega da direita um <enorme $>$ homem azul < (completamente azul) >, <aproximando-se bastante do proscénio > e arrastando uma grande e pesada barra vermelha estridente. Ele dobra-se sob o gigantesco peso que carrega. Uma das extremidades da barra assenta-lhe sobre o ombro, a outra é arreastada chão fora. Ele sai.

Longa pausa...

O velho homem lá no alto (com um tom calmo, quase mecânico, mas simples): "Bom, agora o sol (tem de) pode (quase) nascer."

Por detrás da inclinação íngreme da colina, da direita para a esquerda, elava-se o gigantesco sol de um vermelho tão estridente que tudo asfixia e esmaga.

Todos permanecem imóveis.

O sol já cobriu praticamente a metade do fundo. (O fundo está de um violeta muito sombrio). E de repente faz-se escuro total.

\section{Fim}




\section{[SEM TÍTULO]}

\section{[1]}

Sol dourado $\}$

\} sobre um céu azul

Sol prateado $\}$

Sobre a esquerda em baixo, uma nuvem verde clara ácida [Esboço]

À direita uma árvore cor-de-rosa.

Chão preto. < < cavaleiro branco. Crianças.

Realejo e canto. Meros

soldados. Cocotes. Pantera

ma.[lhada]. O cav.[aleiro] bra.[nco] com

uma espada de vidro [?] e vestes amplas

ligeiramente envasés.

Céu cinzento com grossas camadas de nuvens paralelas

[Esboço]

No meio uma fonte amarelo vivo

Um homem de sobrecasaca tira de dentro dela o balde.

O cháo é de um vermelho escuro. O homem e a voz atrás.

O céu violeta com uma nuvem em forma de couve-flor preta

no meio.

[Esboço]

Cortina verde

O chão branco

À direita algumas pessoas azuis de pé apertadas umas contra as outras

À esquerda " " vermelhas sentadas apertadas umas contra as outras

O par de apaixonados a cavalo. 
Por detrás do mar azul ondas brancas

O céu azul claro, perto do mar cor-de-rosa

À esquerda uma grande palmeira com folhas largas [Esboço]

\section{À direita tendas brancas}

No meio, índios sentados sob a forma de um triângulo, enfeitados

com penas, grandes anéis no nariz, um grande número de ornamentos compostos por: cadeias de crânios humanos, grandes moedas, dentes, pauzinhos pintados, conchas, etc.

$<$ Chão \{preto\} amarelo estridente $><\mathrm{O}$ barco $>$. Atrás um combóio. Apita. Baleia.

[Esboço]

Tudo preto. Uma figura branca atravessa o palco.

Lua crescente prateada [Esboço] está supensa no ar. 


\section{Botequim}

Linsmuh: Meus senhores, declaro aberta a reunião.

X.: Eu peço a palavra. Proponho que na abertura da sessão, mencionemos não apenas os cavalheiros, mas também as damas. Digamos, o presidente deveria no futuro dizer "meus senhores e minhas senhoras".

Schwunz: Acho isso supérfluo. Não nos dirigimos aqui a senhores e senhoras mas a artistas.

Condessa de.: Sim... acho bem... sim... isso dos artistas.

Empregada de mesa (entrando na sala): Desejam alguma coisa para beber?

Linsmuh: Menina, traga um sifão para este senhor. (Apontando para Kuku) Ele está com

\section{[1 VERSO]}

dores de cabeça

Condessa de.: Não, não, não lhe dê nenhum sifão.

Kuku: Não percebo... porque (elevando os sobrolhos) tenho tanta sede...

Condessa de.: Mas peço-te, peço-te... Sabes que...

Kuku: Ah! Sei melhor do que tu

Condessa de.: Kuku, Kuku, peço-te, não, suplico-te...

$\mathrm{Tu}$ bem sabes (sussurra-lhe ao ouvido)

Kuku: (eleva ainda mais os sobrolhos, com voz fraca)

Bom, está bem, dê-me...

X.: Dê-lhe rum. 
Fuzus: (com voz grave) Ah, sim, Dê-lhe rum.

Kuku: Não, não, não... Eu não quero nenhum rum.

Bä: (furioso de repente) Porque é que não quer rum [?]!

$\mathrm{O}$ artista trabalha pelo dinheiro, o artista trabalha pela glória! ${ }^{24}$

Neinsa (?) (sussurra-lhe em voz alta): não, não, eu estou a falar do álcool, do rum, está a perceber, e não da glória. A bebida rum, não da glória. Beber - rum. Nada de glória - nada de dinheiro.

Bä (com curtas inspirações pelo nariz): Desculpem, eu não percebi nada.

Linsmuh: Sim, mas peço-lhe que me perdoe.

\section{[2 VERSO]}

Este idealismo de nada serve. Matisse também trabalha pela glória.

Vozes: Sim, rum. Matisse, a glória, Cézanne... Gogh... [?] Strauss é um grande músico... 2 m e 50... enorme! Uma bela mulher... Nós não nos dirigimos aos senhores...

Erbsmuh: (tocando a campainha de mesa) Sim, meus senhores e ... uh (lançando um olhar tímido àquele que se cala) e... (murmurando ao ouvido daquele que se cala):

Aquele que se cala (acena com a cabeça com solenidade)

$\{$ Erbs $\}$ Lindsmuh... e as senhoras, queria pedir-vos...

Dr. Klappmann (baixando os olhos e tapando-os com a mão): Parece-me

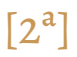

que acabámos de decidir que naaada tinhamos aqui a ver com damas e cavalheiros, mas com artistas.

24 Em português não é possível traduzir a palavra alemã Ruhm (glória) para manter o jogo homofónico com a palavra Rum (rum). 
Bä (levanta-se de repente e precipita-se para fora da sala).

Todos: Onde é que ele vai? Onde? Ele foi-se embora! Eu também vou! Volta! Agarrem-no.

$\{$ Erbs\} Linsmuh (precipita-se atrás de Bä e sai porta fora)

Todos (silêncio embaraçador)

Empreg[ada] de mesa: Os senhores desejam beber qualquer coisa?

\section{Pausa}

\{Schwunzl\} Empregada: Os senhores...

Schw.[unzl] (em tom exigente): Traga-me uma...

\section{$\left[2^{\mathrm{a}}\right.$ VERSO $]$}

Linsmuh (entrando com um sorriso desencorajador): Bä está aí a chegar. Ele não foi à casa de banho... Ele apenas foi lá fora... Ele está aí a chegar.

Todos: O Bä é uma pessoa muito, muito boa.

Condessa de: Ele está terrivelmente apaixonado por mim... Quero contar-vos uma coisa. Quando eu ainda era uma criança de 25 anos, altura em que o meu pai ceava $4 \mathrm{X}$ por dia em casa do Czar, um monge apaixonou-se por mim. Ah, que maravilha! Ele era um sujeito estranho.

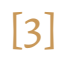

Müstrich: Imaginei que estávamos aqui por causa de uma reunião...

Dr Fi: Eu ainda não recebi nenhum voto... Apenas queria dizer que devíamos... votar.

Linsmuh: Sim meus senh... eu queria dizer (olhando para Schwunzel), meus artistas, nós estamos aqui para uma reunião. 
X: Muito bem! Queria então dizer alguma coisa sobre a planeada exposição. Há alguns...

Vozes: Isso não faz parte da ordem de trabalhos, isso é supérfluo. Alguns de nós também são

Linsmuh (toca a campainha de mesa): Não faz parte da ordem do dia falar de alguns de nós.

Kuku (suspira)

\section{[3 VERSO]}

Dr. Klappmann (olha para o relógio e bichana qualquer coisa no ouvido de Linsmuh)

L.[insmuh]: Sim, claro... Ainda temos de ir ao aeródromo... Hum! Eu explico...

\{Domten\} Bä (entra, \{atrás dele o senhor Bä\} inspirando como antes): É um...

Domten (entrando com rapidez e empurrando o senhor Bä para o lado, aproxima-se do senhor Kuku, tirando a boina por cortesia e falando em voz alta): Senhor Barão, a enfermeira chegou!

Kuku (muito espantado): Enfermeira?

(K.): Porquê?

Domten: O senhor Barão mandou chamar

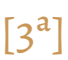

a Titi.

Kuku (cala-se, embaraçado, depois sorri muito suavemente e bem disposto): Ah, cometo sempre o mesmo erro. O que eu queria era um chá, chá, e não a Titi. 
Dr. Fi: Eu não tenho direitoa voto... Mas acho estranho que ainda possamos ver hoje o Drusmann [?], uma vez que...

Coro: O Ciclista Vermelho ${ }^{25}$ põe-se em andamento!

Fuzus (com uma voz profunda de baixo): E o Cavaleiro Azul também.

\section{Cortina}

(Faz-se escuro)
25 Rote Radler (Ciclista Vermelho) é o nome de um percurso de bicicleta que se fazia no tempo de Kandinsky dentro da cidade de Munique, por vezes nos arredores. 
A. [SEM TÍTULO]

[cerca de 1911]

[SEM TÍTULO] ${ }^{26}$
26 manuscrito que aqui se traduz é um primeiro esboço para o texto que se segue, intitulado Prefácio para Composições para Palco. (Boissel, 1998: 142)

O palco enquanto tal fornece o meio mais rico e mais correcto para reunir as artes. Não existe nenhum meio, colocado à disposição desta ou daquela arte, que possa, mesmo que de forma aproximada, comparar-se à potência do palco, porque ele reune em si todos estes meios. É assim que nele podem ser utilizados o som, a cor e o movimento. Ao descrever-se o som, nele entra a palavra, que é ela própria som, mas associada a uma relativa concretude. A palavra é o meio do drama sob toda equalquer forma, o som em forma pura é o meio da música. A cor é o meio da pintura. O movimento é o meio do ballet. Estes meios em breve passaram a ser apresentados separadamente no palco (o drama em sentido estrito), em breve unindo-se a dois (ópera, ballet).

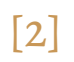

Tanto quanto parece, a completa união das artes em palco é a ópera, desde a época de R. Wagner. Wagner lutou por isso: 1) ao fornecer sentido ao uso dos elementos separados da ópera; 2) ao combiná-los, ao entrelaçá-los. O movimento que antes de Wagner era quase entendido como desnecessário, no entanto, era considerado, no mais elevado grau, como um atributo não essencial da ópera (mãos apertadas contra o peito para exprimir o amor, mãos elevadas em direcção ao céu como sinal de oração, mãos a gesticularem para os movimentos do coração, etc.). Foi ele que estabeleceu a ligação destas expressões com a música: ele (o movimento) submetia-se ao compasso musical. Naturalmente que esta ligação é puramente exterior, e o movimento, i. e., o seu sentido interior, é totalmente desaproveitado.

A música

sujeita-se também à exterioridade do movimento, reflectindo os golpes de martelo, o assobiar do ferro na água, etc. E ao movimento e à música é atribuído o papel do imitador ou, na melhor das hipóteses, o do espelho. As cores estão completamente sujeitas à acção exterior do drama, ao qual Wagner ten- 
tou conferir um lugar essencial no seu palco. Mas o seu dramanão passa de uma narrativa exterior como acontece nas outras óperas. Continuava a ser o mesmo som que tinha sido chamado a participar na caracterização dos heróis, mas também esta caracterização se mantém exterior, ela revela-se como uma etiqueta colada à figura do herói.

\section{[4]}

Uma outra forma de utilização do palco é a representação do drama, que Maeterlinck foi buscar à forma das narrações da vida quotidiana. Ele foi um dos primeiros a prestar atenção ao valor interior da palavra (enquanto sonoridade concreta), que está oculto sob a sua forma literária exterior. Mas Maeterlinck não conferiu nenhum lugar específico ao movimento; este continua a ter para ele o mesmo papel auxiliar como no drama realista. A pintura partilha este destino, i. e., ela limita-se a reproduzir a vida, espaços, etc.. O próprio Maeterlinck tem consciência

da completa insignificância deste papel que, em caso de necessidade, o leva a suprimir toda a cenografia. Em todo o caso, quando os lemos, os dramas de Maeterlick, eles nada perdem, antes ganham com isso, o que demonstra com clareza o papel fortuito, tanto do movimento como também da pintura.

Existe ainda uma arte que usa o palco - o ballet, que é sobretudo constituída por movimento tanto individual como de conjunto. De facto, o movimento perdeu totalmente a sua integridade primordial, tornando-se afinal num mero ritmo exterior. Não importa qual o ballet em que se possa suprimir uma dança, colocando em seu lugar uma outra, misturando-as a seguir, e a totalidade do ballet não será afectada, pois ela não existe de todo.

\section{[6]}

E, no entanto, todos estes elementos individualizados possuem uma totalidade interior, que talvez em breve seja capaz de romper o revestimento exterior. Dentro em pouco virá o tempo em que tudo será perceptível não apenas pelo ouvido, olho ou cabeça-aquilo a que chamamos coração -, mas também pela alma. O palco é um meio poderoso para o efeito sobre a alma; pois quanto mais ricos forem os meios de expressão, tanto mais forte será o resultado - estas vibrações interiores, que não têm nome, mas que são o eterno objectivo de qualquer arte. 
Que ressoe um qualquer som, não importa qual. Imediatamente lhe respoderá uma certa

\section{$[7]$}

vibração interior. Que ao olho seja perceptível uma mancha branca ou colorida e o resultado será de novo uma vibração interior. É esse resultado que provoca também todo o movimento (passivo ou activo). As vibrações são indeterminadas. Se virmos uma grande mancha vermelha, podemos sentir diferentes vibrações, que exactamente por isso serão muito difíceis de definir, porque elas dependem do estado momentâneo da psique, tal como de particularidades próprias de cada pessoa singular. Mas uma longa permanência num meio colorido provoca uma absoluta excitação que destrói por vezes o sistema nervoso.

\section{[8]}

Uma pessoa fechada numa sala replecta com uma cor forte sente um apaziguamento que por vezes chega a alcançar a paralisia dos membros inferiores. Foram feitas diversas tentativas para determinar o significado da influência tanto das cores como dos sons na psique, mas é duvidoso que o sucesso de tais investigações seja possível, porque somos demasiado influenciados pelas representações literárias. O homem moderno está em geral habituado a procurar em tudo um significado prático directo: quer se trate de um gesto, da cor ou de uma forma real. Apenas a música continua a ser arte abstracta,

i. e., ela exerce efeito sobre o "sentimento". Os "retratistas de costumes" também fazem da música um meio de transmitir exterioridade aos fenómenos. Isto é aquilo a que chamamos de música-programa. Eles não se conseguem afirmar e continuam a constituir uma minoria. Mas este fracasso explica-se melhor através da inaptidão da forma musical para perseguir objectivos isolados, em vez de ansiar, com zelo, por alcançar pelo menos um campo da arte em seu apogeu, sem o reduzir a um papel acessório; através da aspiração de pelo menos salvaguardar alguma coisa "para a alma". Mas a alma enterrada em algum lugar nas profundezas, enterrada por todos os tipos de aparências exteriores, não pode ser lançada ao mar, como muitos pensavam. 


\section{[10]}

Ela teve de sair e saiu mesmo, e é possível que ela já reapareça renovada. Isso ajuda a conseguir evocar essas almas que dormem como se tivessem morrido, eis a questão das artes. Elas [as artes] têm todas de se unir e cada uma elevar com seus meios o poderoso vórtice e varrer o lixo do exterior. * É exactamente isto que é a união das artes, onde todas elas falam em conjunto, mas cada uma na sua própria língua, e involuntariamente há um impulso subjacente às nossas composições.

\section{[11]}

Queremos que cada uma das artes se coloque em primeiro plano quando ela, e especialmente ela, for capaz de dizer num minuto o que for necessário e da maneira mais forte possível. Uma outra questão é nesta altura a que se prende com um cenário favorável ou, se necessário, ela pode ser silenciada. Graficamente, este princípio condutor é representado por três curvas:

1. som

2. cor

[cf. Fig. 12, b]

3. movimento

que vão numa única direcção e que, em alternância,

\section{[12]}

alcançam a mais elevada altura, i. e., "ressoando" mais fortes do que as outras, atraindo sobre si próprias uma atenção especial. Ao mesmo tempo, esforçamo-nos por utilizar estes meios não para descrever as coisas exteriores mas para excitar o movimento interior da alma. É por isso que utilizamos também a voz, às vezes muito simplesmente sem palavras. Predominantemente a própria voz provoca ela mesma uma certa emoção e por vezes uma emoção mais forte quando a palavra não está em jogo, aspecto que obscurece com frequência esta significação interior da voz enquanto som musical e enquanto som psíquico.

\section{[13]}

Assim, o palco permite a possibilidade de movimento para todo o tipo de arte e mesmo para a pintura que, estando associada à parede ou à tela, está privada de movimento no tempo. Todos conhecemos o poder que tem a utilização numa língua de palavras de outra língua, especialmente quando se trata de palavras
* Quando falamos de "lixo" exterior, não queremos chamar de lixo às coisas nem a tudo o que é exterior, porque o exterior também é de certa maneira interior. Mas aqui não podemos envolver-nos neste tipo de pensamentos. 
fortes, claras e ricas. Se uma tal mistura de diversas línguas não tem objectivo, então essa mistura desencadeia uma impressão manipuladora e desagradável de afectação. Se por seu turno [a mistura] é adequada, ela torna o discurso consistente, forte e claro. Da mesma maneira acontece no nosso domínio,

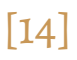

no qual nos esforçamos também por afastar toda a afectação como um elemento perturbador e abjecto. Aquilo que criámos é provocado por uma determinada necessidade interior mas que também pode ser indeterminada. Nós tentamos falar a linguagem das artes. Aqueles que se interessarem por nos escutar que o façam com os ouvidos da arte, i. e., com o ouvido interior, o ouvido da alma. Aqueles que tiverem ouvidos, podem escutar! 


\section{B. PREFÁCIO PARA AS "COMPOSIÇÕES PARA PALCO"}

[cerca de 1911]

\section{PREFÁCIO}

Para as "Composições para palco"

W. KANDINSKY

Ainmillerstr. 36/II

München

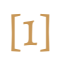

Cada arte tem a sua linguagem, i. e., os meios que só a ela pertencem. Estes meios das diversas artes estão pelo seu aspecto exterior muito distantes uns dos outros, mas estão unidos em torno do mesmo objectivo. Cada meio deste tipo é um canal que vai da alma do artista à alma do "público". Tudo o que é indeterminável e o que é determinável, que passa

\section{[2]}

por este canal, que vai de alma a alma, é o conteúdo da arte. Quanto mais importante for este conteúdo e mais perfeito for o canal que o conduz, maior será o resultado da obra de arte. Mas como cada arte tem a sua linguagem, capaz de exprimir as diferentes partes de um conteúdo geral com uma força específica, a maior grandeza exterior* do conteúdo obtem-se através da união das diversas artes como um todo. Se uma tal união é utilizada sem objectivo, então

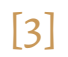

surge qualquer coisa como uma linguagem mundana em que são introduzidas as palavras de uma língua estrangeira que não conduzem à força de expressão do pensamento mas a um brilho exterior prejudicial. A união dos meios das diferentes linguagens deveria estar em conformidade artística com o objectivo em vista.

O palco em si representa o mais rico e o mais cómodo meio de união das artes. Aqui podem unir-se a música (som), a pintura (cor), o drama** (movimento). O significado do som abrange também

\section{* Anotação na p. 2: [Esta anotação encontra-se na p. (1 verso)] \\ Aqui a referência diz respeito ao volume, à duração e à plenitude. Infinitamente "grande" pode significar a emoção interior que não é senão provocada por um único golpe desenhado com engenho no papel. Mas esta emoção será sobretudo grande através do seu aprofundamen- to na alma. Esta grandiosidade extrema no que diz respeito ao volume, à duração e à plenitude é alcançada sob as condições de união de todas as forças que gratificam as artes. (Boissel, 1998: 150)}

\footnotetext{
*Anotação na p. 3 [Esta anotação encontra-se na p. (2 verso)] Por drama entende-se também o ballet que utiliza igualmente 0 movimento na sua forma pura.
} 
[4]

a voz humana, que também é ela mesma som, mas revestida de uma relativa capacidade de concretização.*

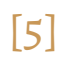

Estes meios em breve passaram a ser utilizados de forma separada em palco (o drama no sentido estrito do termo), em breve em dupla ligação (ópera, ballet). Visivelmente, a união mais completa das artes em palco é, desde Ricgard Wagner, a ópera, porque neste caso se manifestam duas tendências:

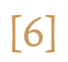

1) atribuir um sentido ao uso de elementos separados da ópera,

2) combiná-los, entrelaçá-los.

O movimento, que era antes de Wagner um atributo quase desnecessário e pueril da ópera (mãos apertadas contra o peito para exprimir o amor, mãos elevadas em direcção ao céu como sinal de oração, mãos a gesticularem para os movimentos do coração, etc.), estabeleceu a ligação destas expressões com a música: ele (o movimento) submetia-se ao ritmo musical. Naturalmente que uma tal ligação

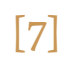

é puramente exterior: o sentido interior do movimento permanece completamente desaproveitado. E muitas vezes a música também se sujeita exteriormente à acção (movimento em sentido alargado do termo), reflectindo os golpes de martelo, o assobiar do ferro na água, etc.. Parece que um elemento reflecte o outro, mas como este reflexo é puramente exterior, sem ter origem numa necessidade interior, ele faz lembrar acções próprias do ser humano numa reprodução simiesca. Da mesma maneira

\section{[8]}

a outra forma exterior da ligação do som com o movimento (em sentido alargado) - é a «caracterização» musical das personagens. Como esta caracterização também é exterior, ela assemelha-se a uma etiqueta que seria colada musicalmente à personagem. O terceiro elemento, que foi utilizado por
** Anotação:

Toda a palavra pronunciada é constituída por 3 elementos:

1) Representação puramente concreta ou real (por ex. o céu, uma árvore, uma pessoa)

2) Todo o som psíquico, por assim dizer, que não é exprimível através de palavras (será que é possível exprimir qual é o efeito em nós das palavras «céu», «árvore», «pessoa»?)

3) O som puro, pois cada palavra tem a sua própria sonoridade que lhe é intrínseca. É assim que se forma de maneira geral o carácter concreto relativo da palavra, à qual, por exemplo, Maeterlinck prestou atenção***.) Fim da anotação.

*:* A propósito da anotação da página 4 Esta anotação suplementar encontra-se na p. (4 verso) Se isolarmos a voz da palavra (por ex. o canto sem palavras), apenas restará a musicalidade do som mas com um carácter particular, porque antes de mais nesse som é o próprio ser humano que ressoa em consonância ou é até uma representação semi-consciente feita dele mesmo enquanto ser vivo, que nos é próxima ou que nos é totalmente idêntica. 
Wagner para crioar uma arte monumental, é o drama. Independentemente da sua vontade de também querer introduzir uma renovação neste elemento, o seu drama pouco se distingue nos meios

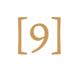

de um libretto de ópera comum.

A verdadeira esfera de utilização do movimento é o ballet. Aqui o movimento individual e o movimento da massa são o principal meio de expressão. Infelizmente ele quase nunca é utilizado na sua forma pura, servindo apenas como linguagem bastante ininteligível para exprimir os sentimentos comuns (amor, ódio, tristeza, medo, etc.). Como aspecto artístico do movimento no ballet é apenas de mencionar o seu carácter rítmico. Ele [o movimento] funde-se ritmicamente

\section{[10]}

com a música, fornecendo ao som uma forma mais concreta. A dependência interior entre os movimentos individuais é tão restrita que qualquer que seja a dança ela poderá ser substituída por uma outra qualquer. Nesse sentido, a totalidade do ballet não sai prejudicada, porque ela, de facto, não existe.

Exactamenete esta totalidade interior, deixada quase sem atenção, dos simples elementos separados do palco (som, cor, movimento), é o fundamento destas [nossas] composições.

\section{[11]}

Considerando justamente esta totalidade interior como base das construções, a escolha não foi feita com base numa forma cénica determinada e reconhecida como integral. Todos os 3 elementos desempenham da mesma maneira um papel necessário, em consequência do qual estas composições não puderam ser inseridas nem na forma de ópera, nem na forma de ballet, nem na do drama. Exactamente estas composições anseiam por conferir, p. ex., à música, um lugar de primeiro plano somente no caso

\section{[12]}

em que exectamente a forma musical é a mais expressiva e a mais capaz de criar a «disposição anímica» exigida. A música passa completamente para 
segundo plano, quando a acção, p. ex., da cor ou do movimento é suficientemente expressiva, não podendo ser enfraquecida pelo vigor da música. Em breve virá o tempo em que deixaremos de nos aperceber das obras de arte através do olho, do ouvido, da cabeça, aquilo a que chamamos o coração.

\section{[13]}

A arte não é um acepipe, nem sequer existe para sentidos mais requintados, ela é antes o pão quotidiano da alma. O palco é o meio mais poderoso do efeito sobre a alma, quanto mais ricos forem os seus meios de expressão, tanto mais forte será o resultado: cada vibração interior que não tem nome, é uma vivência anímica sem palavras.

Que soe qualquer que seja o som. De imediato lhe responderá uma determinada

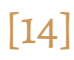

vibração interior. Que o olho descubra qualquer que seja a mancha colorida e de novo haverá uma vibração interior, a qual será provocada também por todas as espécies de movimentos (passivos e activos). Estas vibrações são indeterminadas, mas é exactamente nisso que está a sua riqueza e a sua profundidade, porque a indeterminação é a esfera das possibilidades.

O período materialista que temos estado a viver conduziu maioritariamente a que passássemos a valorizar as práticas mais diversas de todos estes fenómenos. Uma

\section{$[15]$}

cor, que é em si uma força, foi submetida a objectivos materialistas, a que estão agregados os meios de representação, p. ex., a representação da natureza exterior. Desde a época de Giotto que se mantém a ideia de que as cores correspondem a uma certa representação mais ou menos abstracta: ao branco-a pureza, ao verde - a esperança, etc. Também vemos alusões parecidas no caso de Delacroix. Mas não foi por acaso que acabámos de nomear representações semelhantes comparáveis mais ou menos a representações abstractas:

\section{[16]}

a pureza e a esperança são sem dúvida materiais em comparação com as mencionadas vibrações indeterminadas. *
* Anotação.

As experiências de médicos mostraram que, p. ex., a corvermelha em excesso pode conduzir à completa destruição do sistema nervoso através da excitação produzida; a cor azul pode provocar a paralisia das extremidades inferiores. 
Idêntica é também a influência do som. Assim, aquilo a que chamamos música «de programa» não o conseguiu reduzir à mera função de servir o exterior. Talvez se pudesse concluir

\section{[17]}

a partir deste facto, que a música não só não é adequada a experiências deste tipo, como também há uma aspiração inconsciente de a preservar "para a alma" como um domínio no campo da arte.

O papel de uma linha curva que corre, ondula, ou que se mantém tranquila, se expressa como forma redonda ou angulosa, e a sua influência sobre a psique do observador são igualmente observáveis de modo constante: não é por acaso que a linha, e só ela, é chamada de "tranquila" ou "que segue em frente".

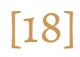

Nestas [nossas] composições são estas forças interiores dos meios individualizados das artes individualizadas que aspiram também a unir-se numa totalidade acústica. Todas as artes têm de se unir para elevarem o protentoso turbilhão que varre o lixo da exterioridade. Que todas as artes falem em conjunto, mas cada uma na sua própria língua. Quando uma delas se manifesta, então as outras criam, ou um meio favorável, ou - se possível - desaparecem mesmo.

\section{[19]}

Graficamente, este princípio condutor é representado por três curvas: 1 som

2 cor [cf. Fig. 12, d]

3 movimento

que vão numa única direç̧ão e que, em alternância, alcançam a mais elevada altura, i. e., «ressoando» mais fortes do que as outras, atraindo sobre si próprias uma atenção especial.*

Aqui tratou-se menos de princípios de utilização de um tal meio

\section{[20]}

do que do seu valor interior. É que para a sua utilização não existe princípio, ou melhor, não existe temporariamente. Todas estas construções não são fundadas sobre projectos arquitectónicos calculados e pesados, mas especi-
* Anotação na p. 19 [Esta anotação encontra-se na p. (18 verso)] Esta representação gráfica é sem dúvida esquemática. A momtagem desta ou daquela linha ondulada tem repercussões sobre as outras, não de natureza gráfica mas como necessidade interior. 
ficamente sobre o sentimento, que é sempre será um estímulo, uma inspiração e um construtor. Aquilo que aqui foi feito é provocado

por uma necessidade interior, talvez hoje indeterminável mas determinada. A aspiração fundamental destas composições é serem capazes de falar a língua pura da arte pura.

Kandinsky 


\section{SOBRE COMPOSIÇÃO PARA PALCO}

[1912]

Reprodução do texto publicado em 1912 no

Almanaque Der Blaue Reiter (O cavaleiro Azul)

\section{[103]}

Sobre composição para palco

de KANDINSKY

Toda a arte tem uma linguagem própria, i. e., ela possui os meios que só a ela dizem respeito.

Assim, cada a arte é qualquer coisa de fechado em si mesma.

Cada arte é uma vida independente. Ela é um mundo à parte e basta-se a si própria.

\section{[104]}

Por isso os meios das diversas artes são do ponto de vista exterior completamente diferentes. Som, cor, palavra!..

No seu fundamento interior final estes meios são totalmente os mesmos: o objectivo finalapaga a diferença exterior e desvela a identidade interior

Este objectivo final (o conhecimento) é alcançável através da alma humana por meio de finas vibrações da mesma. Estas finas vibrações, que são idênticas no seu objectivo final, possuem apesar disso e em si mesmas movimentos interiores diferentes e distinguem-se por isso umas das outras.

O processo da alma indefinível e ao mesmo tempo totalmente determinado (a vibração) é o objectivo dos meios artísticos individualizados.

Um complexo determinado de vibrações - eis o objectivo de uma obra.

A soma desses complexos determinados e que produz o constante refinamento da alma - eis o objectivo da arte.

A arte é por isso insubstituível e conforme ao seu objectivo.

O meio de expressão adequado e encontrado pelo artista é uma forma material da vibração da sua alma, que ele está obrigado a materializar custe o que custar. 
$[105]$

Se este meio for o correcto, ele provocará uma vibração quase idêntica na alma do espectador.

Isto é inevitável. Mas esta segunda vibração é complicada. Em primeiro lugar, ela poderá ser forte ou fraca segundo o grau de desenvolvimento do espectador, bem como depender de influências fortuitas (a alma absorvida). Em segundo lugar, esta vibração da alma do espectador fará oscilar também as outras cordas correspondentes da sua alma. Assim, a obra de arte provoca uma excitação na "imaginação" do espectador que continua a "criar obra"** As cordas da alma, que conseguiram ressoar com mais frequência, vibrarão praticamente com a oscilação das outras cordas que foram tocadas antes delas. E às vezes com tanta intensidade, que elas abafam a sonoridade original: há pessoas que através de música «divertida» são levadas ao choro e vice-versa. Por causa disso, os efeitos individualizados de uma obra recebem dos diferentes espectadores uma coloração diferente.

Mas nesta caso a sonoridade original não é destruída, continuando a viver e a realizar, mesmo que de forma imperceptível o seu trabalho com a alma*** Portanto não há ninguém que não seja sensível à arte. Toda a obra e cada meio em particular provocam no ser humano, sem excepção, uma vibração da alma, que é idêntica à do artista.

\section{$\odot$}

\section{[106]}

A identidade interior dos meios individualizados das diferentes artes, identidade essa que tem sido, em última instância, a base acessível à observação, sobre a qual se tenta sustentar e fortalecer uma sonoridade particular de uma arte através de idêntica sonoridade de outra arte e, assim, produzir um efeito particularmente poderoso. Eis a eficácia dos meios.

Mas a repetição de não importa que meio de uma arte (p. ex. a música) através de um meio idêntico de uma outra arte (p. ex. a pintura) é apenas um caso, uma possibilidade. E se essa possibilidade também for utilizada como um meio interior (p. ex. com Scriabin) ${ }^{* * *}$, assim, no campo da antítese e da composição complicada, encontramos primeiro um antípoda dessa repetição e, mais tarde, uma série de possibilidades situadas entre a coação e a contração. Este é um material inesgotável.
* Hoje em dia, as encenações esforçam-se por utilizar a "colaboração do espectador", com a qual os artistas sempre contaram. Daí a aspiração que apareceu de deixar qualquer coisa de não-dito, um certo espaço que separa a obra do último grau da sua expressão. Este inacabamento do pensamento a exprimir foi exigido com uma particular insistência, como elemento incondicional da composição, por Lessing e por Delacroix. Este espaço é precisamente o domínio livre no qual a imaginação do espectador é convidada a criar.

** Eis porque com o tempo cada obra se torna verdadeiramente "compreensível".

*:* Kandinsky faz aqui referência a um artigo de L. Sabanejew, publicado no Almanaque O Cavaleiro Azul. Nesse artigo é destacado o trabalho de Scriabin não só como compositor mas essencialmente como alguém capaz de juntar todas as artes, em particular a música, a palavra e o "movimento plástico". Scriabin cria um escalonamento no qual integra também, como artes secundárias, a luz e a fragância. É na sua obra Prometeu que o compositor melhor articula a música com o jogo das cores, criando correspondência entre sonoridades e cores. Cf. L. Sabanejew, Prometheus von Scriabin in Wassily Kandinsky und Franz Marc (ed.) Der Blaue Reiter, München, Zürich: Piper, 2000, 107-124. (N. T.) 
O séc. XIX apresentou-se como uma época em que a criação interior se mostrava distante. O interesse demonstrado quase exclusivamentepelos fenómenos materiais e e a sua concentração sobre o lado material desses fenómenos conduziu logicamente ao afundamento das forças criadorsa no reino da interioridade, que à primeira vista conduziu à deterioração em último grau.

Desse grau de unilateralidade se desenvolveram naturalmente outras unilateralidades.

Tal acontecendo também no palco:

1. também aqui (como noutras áreas) foi necessário ser capaz de elaborar de forma detalhada as partes já existentes (previamente criadas), as quais, por conveniência, foram severa e definitivamente separadas umas das outras. Isso reflecte a especialização que sempre surge quando não se criam novas formas e

2. o carácter positivo do espírito de época (Zeitgeist) só poderia levar a uma forma de combinação igualmente positiva. Pensava-se de facto: dois é mais do que um, e procurava intensificar-se cada efeito pela repetição. No efeito interior, no entanto, pode ser o contrário, e muitas vezes um é mais do que dois.

Do ponto de vista matemático, $1+1=2$. Do ponto de vista anímico, $1-1=2$.

\section{[107]}

Adenda 1. A primeira consequência do materialismo, i. e., a especialização e elaboração posteriores, puramente exteriores, das partes individualizadas a que ela deu origem, conduziu à petrificação de três aspectos de obras cénicas separadas umas das outras por altos muros:

1. o drama,

2. a ópera,

3. o ballet.

a) O drama do séc. XIX revela-se como uma narrativa mais ou menos refinada e aprofundada de um acontecimento de carácter mais ou menos pessoal. É normalmente a descrição da vida exterior, na qual a vida interior do ser humano (elemento psicológico) representa um papel, na medida em que ela está ligada a essa vida exterior*. O elemento cósmico falta completamente.

$\mathrm{O}$ acontecimento exterior e a ligação exterior da acção constituem a forma do drama actual.

* São poucas as excepções. E também estas poucas (p. ex. Maeterlinck, Os Espectros de Ibsen, A vida do Homem de Andrejew, entre outros) não abandonam as formas do acontecimento exterior. 
b) Aópera do séc. XIX é como um drama, no qual se faz intervir a música como elemento principal, embora o aprofundamento e o refinamento do elemento dramático sofram com isso fortemente. Ambas as partes estão totalmente ligadas entre si do ponto de vista exterior. Isto é, a música ilustra (e por vezes reforça) a acção dramática, ou é a aç̧ão dramática que é chamada a resgatar e a explicar o conteúdo musical.

\section{[108]}

Essa ferida foi notada por Wagner e ele tentou auxiliála de vária s maneiras. A sua ideia fundamental foi ligar entre si de forma orgânica as partes individualizadas da ópera e desse modo conseguir criar uma obra monumental".

Ao repetir um e o mesmo movimento exterior em duas formas de substância, Wagner procurou fortalecer os meios a alcançar e elevar esse efeito a uma altura monumental. O seu erro, neste caso, foi a ideia que ele tinha de que dispunha de um meio universal.

Este meio é, na verdade, apenas um de uma série de possibilidades muitas vezes poderosas da arte monumental.

Mas para além do facto de que uma repetição paralela é apenas um meio, e que essa repetição é apenas exterior, Wagner concedeu-lhe uma nova forma que a deveria orientar daí em diante. Antes de Wagner, por exemplo, o movimento tinha apenas um sentido puramente exterior e superficial na ópera (talvez apenas degeneração). Ele era um apêndice ingénuo da ópera: as-mãos-no- peito - o amor, o-levantar-dos-braços - a oração, o-agitar-dos- braços-no-ar - emoções fortes, e por aí fora. Essas formas infantis (que ainda hoje podem ser vistas todas as noites) estavam relacionadas exteriormente com o texto da ópera, que continuava a ser ilustrado pela música. Aqui Wagner criou uma conexão direta (artística) entre o movimento e o ritmo musical: o movimento subordinava-se ao ritmo.

Mas essa conexão é apenas exterior por natureza. A sonoridade interior do movimento está fora de jogo.

\section{[109]}

Segundo o mesmo princípio, ainda que artístico e embora exterior, Wagner por vezes submeteu a música ao texto, i. e., ao movimento em sentido amplo. O ferro crepitante a queimar na água, os golpes de martelo do ferreiro e coisas ssemelhantes reflectem-se na música.
* Esta ideia de Wagner levou mais de meio século para conseguir passar os Alpes, onde ela recebeu uma espécie de parágrafo expresso oficialmente. $\mathrm{O}$ "Manifesto" musical dos "Futuristas" diz o seguinte: "Proclamer comme une necessité absolue que le musicien soit l'auteur du poème Dramatique ou tragique qu'il doit mettre en musique" [Proclamar como uma necessidade absoluta que o músico seja o autor do poema dramático ou trágico que ele tem de musicar.] (Maio, 1911, Milão) 
Porém, esta sujeição variável de um primeiro elemento a um outro produziu também um enriquecimento dos meios da acção, a partir da qual se podiam formar novas combinações.

Assim, por um lado, Wagner enriqueceu os efeitos produzidos pelos meios individualizados e, por outro, diminuiu o seu sentido interior - o seu puro significado inerior artístico como meio de apoio.

Estas formas são apenas reproduções mecânicas (e não colaborações interiores) dos processos apropriados à acção. De natureza semelhante é também a outra articulação da música com o movimento (no sentido amplo do termo), i. e., a «característica» musical dos papéis individualizados. Esta sonoridade obstinada de uma frase musical que acompanha o aparecimento de um herói acaba por perder a força e afectar o ouvido como um velho rótulo de garrafa que o olho conhece bem. O sentimento acaba por resistir a tais aplicações programáticas consistentes perante uma e a mesma forma*.

Por fim, Wagner precisa da palavra como meio para a narrativa ou para exprimir os seus pensamentos. No entanto, nenhum ambiente adequado foi criado para tais fins, pois as palavras são geralmente abafadas pela orquestra. Não basta fazer ressoar a palavra em muitos recitativos. Mas a tentativa de interromper o canto incessante já causou um tremendo choque na "unidade". Apesar disso, o processo exterior também se manteve intocável.

Partindo do ponto de vista de que Wagner, apesar dos seus esforços para criar um texto (movimento), permaneceu aqui completamente ligado à velha tradição do exterior, ele não se ocupou do terceiro elemento, que ainda hoje continua a ser utilizado isoladamente de uma forma primitiva** - a cor e a respectiva forma pictórica associada (decoração).

\section{[110]}

O processo exterior, a ligação exterior entre as partes individuais e os seus dois meios (drama e música) são a forma da ópera de hoje.

c) O ballet é um drama com todas as suas características já descritas e o mesmo conteúdo. Só que neste caso o carácter sério do drama sofre ainda mais do que com a ópera. Na ópera, para além do amor, encontramos outros temas: relações religiosas, políticas, sociais, nos acontecimentos históricos, adaptadas a uma compreensão fácil e ingénua, elas formam o terreno sobre o qual crescem o entusiasmo, o desespero, a honestidade, o ódio e outros sentimentos primitivos semelhantes. O ballet satisfaz-se normalmente com o amor numa forma infantil, própria de contos de fadas. Além da música, os movimentos individuais e de grupo são usados aqui. Tudo permanece como uma
* O carácter programático atravessa toda a obra de Wagner e encontra uma explicação não apenas na sua personalidade mas igualmente na aspiração de descobrir determinadas formas para a nova criação, uma vez que o espírito do séc. XIX imprime sobre essas formas o selo do "Positivismo".

** Ver o artigo de Sabanejew. 
forma ingénua de ligação exterior. Na prática, são mesmo mantidas ou retiradas à vontade danças individuais. O "todo" é tão problemático que tais operações passam completamente despercebidas.

O processo exterior, a ligação exterior entre as partes individuais e os seus três meios (drama, música e dança) são a forma do ballet de hoje.

Adenda 2. Através da segunda consequência do materialismo, i. e., através do procedimento de adição positiva $(1+1=2,2+1=3)$, foi apenas usada uma única forma combinatória (ou de reforço), que exigia o decurso paralelo dos meis de expressão. P. ex., uma emoção forte é imediatamente sublinhada em música por um fortissimo. Este princípio matemático constrói também as formas de expressão sobre uma base puramente exterior.

\section{[111]}

Todas as formas mencionadas, a que eu chamo formas de substância (no drama - a palavra, na ópera - o som, no ballet - o movimento), bem como as combinações dos meios de expressão individualizados, a que chamo meios eficazes, constituem-se como uma unidade exterior. Todas estas formas provêm do princípio da necessidade exterior.

É daí que flui a limitação, a unilateralidade (= empobrecimento) de formas e meios como um resultado lógico. Gradualmente eles vão-se tornando ortodoxos, e cada mudança minuciosa surge como revolucionária.

Coloquemo-nos no terreno da interioridade. Toda a situação muda significativamente.

1. A aparência exterior de cada elemento desaparece de repente. E o seu valor interior adquire completa sonoridade.

2. É claro que quando o som interior é usado, a ação exterior pode não apenas ser secundária, mas prejudicial como obscurecimento.

3. O valor da ligação exterior apresentar-se-á na sua verdadeira luz, i. e., como uma força que limita e enfraquece, sem que haja necessidade do efeito interior.

4. O sentimento de necessidade da unidade interior vem de si mesmo, que pode não apenas ser reforçado pela dispersão exterior mas também directamente criado por ela.

5. Abrir-se-á a possibilidade de manter para cada um dos elementos a sua própria vida exterior, que é exteriormente contraditória à vida exterior de um outro elemento. 
Se, indo mais longe, conseguirmos obter resultados práticos destas descobertas abstractas, daí resultarão as seguintes possibilidades,

Ad. I utilizar como meio de expressão o único som interior de um elemento,

Ad. 2 sublinhar o processo exterior (= a acção),

Ad. 3 em consequência do qual a ligação exterior cai por si mesma, tal como

Ad. 4 a unidade exterior e

Ad. 5 o aparecimento da unidade interior e dos unúmeros meiso de expressão que antes não podiam existir.

Daqui resulta que a necessidade interior é a única fonte de criação.

A seguinte pequena composição para palco é uma tentativa de criar a partir dessa fonte.

Estão aqui três elementos que se aplicam aos meios exteriores no que diz respeito aos valores interiores:

1. tom musical e o seu movimento,

2. sonoridade físico-emocional e o seu movimento expresso através de pessoas e objetos,

3. tom colorido e o seu movimento (uma possibilidade especial para palco).

Assim o drama surge finalmente de um conjunto de experiências interiores (vibrações da alma) do espectador.

ad 1. À ópera foi-se buscar o principal elemento - a música como fonte de sonoridades interiores -, que de modo algum deverá e3star subordinada ao processo exterior.

ad 2. Ao ballet foi-se buscar a dança, que como movimento actuante abstracto está relacionado com a sonoridade interior.

ad 3. O tom colorido obtém um significado independente e é tratado como um meio em igualdade de circunstâncias.

\section{[113]}

Os três elementos em conjunto desempenham uma função importante, mantendo-se exteriormente autónomos e são ao mesmo tempo são tratados de forma idêntica, i. e., submetidos ao objectivo interior. 
Por isso, a música, por ex., pode ser completamente empurrada para trás ou para o fundo, quando, por ex., o efeito do movimento é suficientemente expressivo e poderia ser enfraquecido pela forte participação musical. $O$ crescimento do movimento na música pode corresponder a uma diminuição do movimento na dança, dando a ambos os movimentos (positivo e negativo) maior valor interior, etc. etc. Uma série de combinações que existem entre os dois pólos: cooperação e reacção. Pensados do ponto de vista gráfico, os três elementos podem executar os seus próprios caminhos exteriores, independentes uns dos outros, e com autonomia.

A palavra como tal, ou associada a frases, tem sido usada para criar uma certa "disposição" que liberta e torna sensível o fundo da alma. O som da voz humana também tem sido usado de forma pura, i. e., sem qualquer obscurecimento através da palavra, através do significado da palavra.

○

O leitor é convidado a não atribuir por princípio à pequena composição "O Som Amarelo" quaisquer fraquezas, mas a colocá-las na conta do autor. 


\section{CRÓNICA}

O problema há muito conhecido que se ocupa do relacionamento interior entre a sonoridade musical e a sonoridade da cor volta a excitar o artista de hoje com uma violência em si particular.

Aproximamo-nos desta questão consequente sob dois ângulos: pela via da ciência positiva - caminho exterior - e pela via das experiências emocionais - caminho interior. Tentamos também explorar de duas maneiras as consequências deste relacionamento, que ainda não é claro: como significado teórico e como aplicação prática.

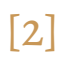

Um palco, do qual não \{podemos\} imaginar os limites,

Sobre este palco um<a> \{peça\} acção.

A que chamamos tragédia:

Movimento. Sons. Colisão. Detonação. Explosão.

Desaparecimento. Aparição. Nenhum princípio. Nenhum fim.

Um turbilhão de poeira - Os planetas estão num vórtice.

Sobre um planeta - \{nós\} - pessoas.

Um acto $\{$ da peça\} da acção em três quadros:

1. Criação do corpo - criação do mundo.

$<$ Revelação $>$ \{do poder\} da vontade de Deus-Pai

\{sou] união -

2. Formação \{do\} princípio da harmonia \{para

o corpo\} - <revelação do > amor - Deus-Filho

3. Respiração do espírito - movimento - revelação

da liberdade - Deus-Espírito Santo.

Antes, um ponto de interrogação.

Depois, um ponto de interrogação.

Nas duas extremidades - um imenso silêncio. 
Os 3 quadros visíveis deste mesmo acto - a decorrerem em conjunto:

O corpo cresce

A união interior tem liugar

\{o espírito\} Uma mão invisível abre a cortina.

Do sol infinito vemos o primeiro raio - liberdade.

○

O que é liberdade?

Liberdade não quer dizer ter a possibilidade de ir ao mesmo tempo para a direita e para a esquerda, mas a ilimitada possibilidade de ir ou para a direita ou para a esquerda... com alegria.

O que é alegria?

Alegria é a possibilidade de seguir o caminho que atrai interiormente.

Qual é o caminho da alegria?

O caminho da alegria é o caminho do conhecimento.

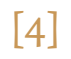

O que é conhecimento?

Conhecimento são as experiências da alma.

○

Qual é o caminho para as experiências da alma?

A arte.

○

Assim a arte reflecte e anuncia o caminho do conhecimento.

Assim a arte actual reflecte o movimento, profetiza a liberdade. 
Qual o meio indispensável à arte para que ela seja reflexo e profecia? A \{o caminho da\} liberdade ilimitada.

Assim a arte já hoje revela o primeiro raio do infinito sol - liberdade.

A arte é \{a criança\}

O profeta dos que hão-de vir.

Este \{esta criança\} profeta vem da terra do acto total.

Assim a arte é também ela o reflexo dos dois primeiros quadros:

a criação do corpo - construção

formação do princípio da harmonia - meios artísticos

$\odot$

Assim a arte é um ser profético que continua a crescer como um corpo autónomo e que através da liberdade serve o espírito. 


\section{POR CIMA DO MURO}

"Mas a razão é sempre mesquinha comparada com o sentimento; uma é naturalmente limitada, como tudo o que é positivo, e a outra é infinita. Usar a razão onde deve existir o sentimento, caracteriza a alma que não é capaz de um ímpeto." (Balzac)

\section{$[\mathrm{AI}]$}

Toda a obra nasce no inconsciente. Na alma forma-se um movimento ondulante. Há tensões que se elevam como grandes vagas, provocam instabilidade, caem, suscitam esperança, voltam a subir e voltam a cair. É como uma pulsação interior poderosa contra as paredes que aprisionam a alma, parecida com as dores de parto. Algumas dessas tensões, alguns desses choques são tão fortes, que é possível prever o seu avanço a todo o momento. E de repente tudo volta a cair. Instaura-se $\{$ vem $\}$ uma calma < de pesado silêncio $>$ e acreditamos que deixámos passar o momento, que tudo desaparecera misteriosamente. Ceros silêncios e certas decepções duram muito. Avançamos com o sentimento de termos perdido qualquer coisa importante. De a termos $<$ deixado $>$ cair no fundo do mar - sem retorno, sem resgate. E então, de novo, há qualquer coisa que se começa a mexer. A alma enche-se, como um púcaro que é fácil de derramar. Andamos às voltas como possessos. Acreditamos. Temos medo. Até chegar a certeza. A hora

\section{$[\mathrm{A} 2]$}

<da última tensão>, do último avanço. De acordo com uma direcção hábil e experimentada, de acordo com a paciência e um amor verdadeiro, a força interior escorre da alma - de forma doce e espumosa -, guia a mão que é irresponsável e encarna na obra.

Em termos concisos e um pouco esquemáticos esta é a história da verdadeira génese de toda a obra.

Mas esta também é a história da verdadeira génese de todo o artista. Cheia de segredos, deixando-se envolver, emaranhando-se, jorrando em erupção, perdendo-se na areia, retida pelas pedras, quebrando vestígios dispersos, surgem, correm, desenvolvem-se, manifestam-se, escondem-se as primeiras emoções da alma do artista. Os ensaios e os estudos encontrados, à primeira 
vista, pré-organizados e «talentosos» raramente são precursores de uma verdadeira revelação futura, de um verdadeiro presente, que geralmente flui como um rio largo, desafiando pântanos, arrastando pedras, derrubando rochas, penetrando nas montanhas, escavando-as. O verdadeiro dom não espalha a sua luz em todas as direcções e não pode exprimir-se com talento sob todas as formas que dele se esperam,...27

O homem grande e forte chorava....

As árvores gemiam, abaladas pelo vento maligno.....

As negras nuvens de chuva precipitavam-se sobre o sol e

devoravam-no.....

Oh!!

$\mathrm{Ou}$ :

Ele entrou no quarto e viu, pousada em cima de uma mesinha amarela, uma maçã verde.....

A tesoura não conseguia cortar de imediato o fio....

Três janelas.....

Um cervo.....

Uma coruja....

E....

Devido a razões amargas e secretas, as pessoas diferenciam-se pelo grau de intensidade das suas vivências. Trata-se de diferenças entre as almas. A alma dura, incapaz de uma vibração, precisa de um soco nas costelas para se sentir abalada.

O homem grande e forte chorava....

Uma frase tirada de um romance em folhetim ao qual a alma mais insensível sucumbe.

As árvores gemiam, abaladas pelo vento maligno.....

Uma frase que sacode o adolescente.

Esta frase não tem necessidade de nada que a preceda nem de nada que a siga: ela é eficaz enquanto tal e... terrível. Ela pode causar uma série de vivências e é por isso todo um poema.

Haverá alguém que ouse pretender não ter estado totalmente subjugado a esta frase - sob esta ou qualquer outra forma - à maneira de um escravo?

$\mathrm{Oh}$ !

27 O manuscrito foi aqui interrompido. (Boissel, 1998: 198.) 
Um único som que tem o poder de exprimir as duas frases acima apresentadas. Neste único som estão incorporados emoção, dor, compaixão, felicidade, entusiasmo, amor, ódio, esperança, desespero.

A maneira como este som é articulado determina o seu conteúdo.

O som -- - a articulação-- - o conteúdo.

Assim uma pessoa pode comunicar a outra os seus sentimentos mais importantes num único som. Com esse som ela alcança a alma da outra pessoa e agita-a até ao mais fundo do seu ser.

E ninguém ousará pretender afirmar que não foi subjugado, não está subjugado, não será subjugado por esse som.

E eis que intervêm bruscamente as forças secretas e amargas e constroem um muro, um muro que apenas o espírito pode atravessar.

Nos exemplos anteriores, quais são os elementos utilizados que possuem o enorme e inquietante poder de mergulhar a alma humana numa tempestade? Quais são as forças que fizeram bruscamente nascer esta tempestade?

O homem grande e forte chorava....

Cinco palavras. Vinte e cinco sons.

Oh!!.....

Um som....

Ou:

Ele entrou no quarto e viu, pousada em cima de uma mesinha amarela, uma maçã verde.

Quinze palavras. Sessenta e cinco sons.

E nenhum efeito. Nenhuma tempestade. A alma repousa e continua a espelhar o céu, o inferno ou o café quente que está a ponto de ser bebido.

E.

Um som.

E a alma silenciosa.

A palestra sobe de tom. $O$ orador quer ser escutado. Ele quer acordar a alma. Ele quer forçar a tempestade. Ele grita. Ele uiva como um louco.

E! E!! E!!!

A alma fica em silêncio e espelha o café quente.

O ouvido irrita-se. Está descontente e o pobre auditor diz - dependendo do seu temperamento -: Ah! Pare, por favor. 
Mas do outro lado do muro assustador, que só o espírito consegue atravessar, vivem muitas, muitas pessoas.

Como é que o espírito as levou para lá?

Três janelas.

E quanto mais calma e impassível for a palestra, mais forte será a tempestade no fundo da alma. A vida estremece. $O$ mundo fala. Tudo adquire uma boca e a alma tem milhares de ouvidos. Criaturas novas e nunca imaginadassuregem e povoam uma nova terra. Ao mundo antigo junta-se um novo.

\section{Processo cósmico.}

Este muro, que só o espírito consegue atravessar, não é uma ilusão. Ele separa dois imensos mundos um do outro, ele mantém afastados entre si dois elementos estranhos. E só o espírito é capaz de os fundir num só.

Tenhamos um pouco de paciência e procuremos estabelecer, para além da comparação exterior, entre os dois tipos de frases, palavras e sons, uma comparação interior. A análise interior é o bastão do caminhante que o mantém e que não falha nem no pântano nem na montanha. Ele é mais sólido do que o aço e não se quebra - devemos apoiar-nos nele com toda a calma. Ele é mais leve do que o ar e transporta cargas mais pesadas do que todos os Zepelins e aeronaves juntos. Devemos apoiar-nos nele com toda a calma.

Vamos utilizá-lo e teremos um pouco de paciência.

Desde a sua primeira vibração que ele nos abre os portões do mistério.

\section{$O$ orador:}

Sobre uma mesinha amarela havia uma maçã verde....

\section{O ouvinte:}

(passado algum tempo, impaciente): E então?

\section{$O$ orador:}

Em cima de uma mesinha amarela havia uma maçã verde.......

\section{O ouvinte:}

(admirado) Sim! E então? 


\section{O orador:}

Em cima de uma mesinha amarela havia uma maçã verde.......

\section{O ouvinte:}

(assustado e de si para si): O homem é doido! O que é que eu tenho a ver com a mesinha e com a maçã!

E nesta frase está a solução do enigma.

O muro assustador, que só o espírito pode atravessar, separa estes dois reinos um do outro. O reino das pessoas que apenas e tão só se agita com as coisas que lhes dizem respeito.

A estas chamaria de subjectivistas.

O reino das pessoas que se agita através de coisas, e que não lhes dizem respeito pessoalmente.

A estas outras chamaria de objectivistas.

E como os objectivistas também conhecem os sentimentos pessoais, eles não estão apenas do outro lado do muro, mas ao mesmo tempo num reino superior.

E só para eles é que a arte é concebida, no seu conteúdo puro e livre de toda a domensão pessoal.

O ser humano a quem só o homem grande e forte que chora comove, uma vez que também ele poderia chorar um dia, a quem só o sol abrasador abala, pois também poderia chover e ficar-se molhado, este ser humano vive o mundo que apenas em exclusivo consigo se relaciona.

E assim continuará a ser para ele o mundo e também a arte, enquanto ele existir. Ele não os vivencia no seu valor interior.

E em particular na pintura, ele quer a todo o preço alcançar o homem forte que chora e o sol abrasador condenado a ser engolido. O que é que ele tem a ver com a maçã verde, que desempenhou um extraordinário papel na história de arte, e que nos permitiu atravessar o muro inquientante, e que rolou diante de nós até ao limiar da pintura pura, dita absoluta, onde a abandonámos com toda a nossa gratidão e a nossa eterna recordação.

Estamos agora do outro lado do muro e encontramo-nos entre pessoas, cuja maçã verde em cima da mesinha amarela conduz a experiências espirituais. 
Que bom, dizem alguns, que a mação não seja vermelha mas verde. E a mesinha amarela.

Não há alegria que dure sempre. Uma mão maléfica corta-lhe a parte de cima, para que ela não possa continuar a crescer. E uma seiva vermelha escorre. E sem esta seiva, nenhum ser humano conseguiu até agora ultrapassar os limites do que lhe era habitual. Nem um único passo. Nem sequer um passinho. A alegria é demasiado subjectiva e na alma ela desperta para uma nova vida as sementes subjectivas inferiores. Crescem as ervas daninhas e a alma parece-se com um jardim votado ao abandono. Morte!

A natureza interior da alma, a sua riqueza interior, a sua perticipação no que é objectivo permite-lhe assimilar as formas mais subtis da arte.

Assim, a diferença entre as duas categorias de exemplos não reside na quantidade de materiais utilizados (uma vez que ela é idêntica nos dois casos: frase, palavra, som), mas na possibilidade que a alma tem de se abrir a seres que são estranhos, que estão fora dela, que nada têm a ver com o seu interesse exterior.

É curioso, pode até parecer à primeira vista enigmático, mas é de facto verdade, que pessoas, as mesmas pessoas que são capazes de vivenciar uma maçã verde no quadro, sejam incapazes de vivenciar a mesma maçã verde, quando ela não é pintada ou - pior ainda - quando ela não se encontre diante dos seus olhos fisicamente. Se fosse de outra maneira, estas pessoas poderiam também vivenciar Três janelas. Mas aí muitas falham. O que é que eu tenho a ver com as Três janelas, é o que elas dizem.

$E$ isto resulta apenas do facto de que a sua capacidade objectiva, a capacidade objectiva de vivenciar o que é objectivo, é ainda muito restrita.

Não é tanto que ela seja restrita, mas que permaneça ligada à materialidade.

Ela é material, mas quer o homem grande e forte que chora - pelo menos as lágrimas - porque ela não pode vivenciar as Três janelas que não têm existência material e porque é preciso que ela exista sob o verde da maçã e sob o amarelo da mesa-

Sim, uma mesa amarela é bonita, dizem elas (que sorte que ela seja precisamente amarela!), mas apenas «mesa» ou apenas «amarela», que tenho eu a ver com isso? 
Todas as pessoas falam a mesma língua. Para umas, o limite situa-se aqui: no ponto em que elas afirmam, terrivelmente afirmam: "o que é que eu tenho a ver com isso?" Para outras, o limite situa-se um pouco mais além, um poucochinho mais além. Mas com uma terrível certeza, com uma determinação aterradora, chega sempre o ponto em que elas dizem: "O que é que eu tenho a ver com isso?"

Que sorte que este amarelo vá bem com o verde, dizem as senhoras ao escolherem os seus vestidos.

Que sorte que o amarelo desta mesinha condiga tão bem com o verde da maçã, dizem as pessoas ao olharem para um quadro.

A mesinha enquanto tal adequa-se à maçã?

Diante de mim arde a lâmpada verde. Ela alumia uma cartão verde. Dois verdes.

Eu preciso da lâmpada, porque ela me alumia.

O cartão dá-me acesso a uma entrada gratuita num salão de pintura. Que fazer com o verde? Com os dois verdes?

A primeira frase sobre o homem grande e forte que chora é uma narrativa dramática com cooperação dos objectos. Trata-se de três elementos que produzem o efeito: 1) aspecto dramático, 2) aspecto narrativo, 3) objecto.

A primeira frase do outro lado do muro é uma narrativa lí

rica com a cooperação dos objectos. Três elementos intervêm sobrepondo-se aos precedentes, uma vez que o elemento lírico e o elemento dramático são idênticos do ponto de vista do seu último valor interior.

E apesar deste reagrupamento e desta identidade, descobrimos entre estas duas frases um abismo insuperável, intransponível, um abismo que corresponde ao muro.

A analogia exterior é aliás perfeitamente secundária. O elemento decisivo é a diferença interior.

É por isso que a analogia interior é determinante. 
Exemplos muito simples e uma lógica muito simples conduziram-nos a esta afirmação que, apesar da sua aparente simplicidade inofensiva, esconde em si uma força que pode assustar muitos.

De forma breve e clara: sem sofrimento podemos, como vimos, separar as cores dos objectos, sendo que elas se mantêm vivas entre as nossas mãos e ficam presas pela sua pulsação, uma mais viva pulsação da alma.

$E$ isso acontece assim, porque a mesinha é um ser autónomo, que conduz a sua própria vida, que tem qualquer coisa a dizer à alma objectiva, qualquer coisa que ora adquire uma tonalidade lírica, ora adquire uma tonalidade dramática que forma o conteúdo de uma vibração da alma e pode elevar-se, e pode elevar-se até formar o conteúdo de uma obra.

E exactamente vivas, vibrantes e cheias de conteúdo são as Três janelas, cuja cor nos é desconhecida.
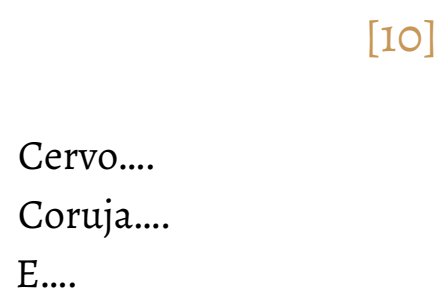

Cervo....

E....

E agora o E já não precisa de ser gritado.

Também a sua articulação em voz baixa e, claro, o seu silêncio profundo estão cheios de conteúdo para nós.

Portanto o "E" foi elevado a material poético e pode perfeitamente sobreviver sem sol, sem nuvens de chuva, sem o homem a chorar.

É assim que um quadro pode passar sem sol, sem nuvens de chuva, sem o homem vestido ou despido, e não precisa nem de mesinhas nem de maçãs.

Apenas as cores na infinita riqueza de possibilidades que elas oferecem e a sua forma pictórica elevam o quadro a obra, que é um ser - e enquanto tal - tem vida própria, conduz completamente os próprios destinos e fala à alma objectiva, que não pensa em si mesma, amando antes o mundo e sobretudo reconhece a linguagem divina.

Munique, Janeiro de 1914.

\section{SOBRE COMPOSIÇÃO PARA PALCO}

[1912]

Reprodução do texto publicado em 1912 no 
VIOLETA

A. PRELÚDIO

1914

[AI VERSO]

\section{Prelúdio $^{28}$}

O pano de boca sobe.

Sobre uma grande tela quadrada um grande círculo vermelho. (10)*

No meio do círculo um pequeno círculo violeta, que cresce devagar e que acaba por cobrir completamente o círculo vermelho. (10)

O círculo vermelho vai, a pouco e pouco, ficando mais pequeno, de tal modo que se forma uma margem azul. Lentamente, o vermelho encolhe-se. Ele desaparece e o grande circulo fica azul. (5)

De repente faz-se escuro.
28 Este Prelúdio não se encontra registado em nenhum outro manuscrito. (Boissel, 1998: 214.)

* Os números indicam o tempo em segundos. 


\section{Cortina violeta}

(uma composição para palco)

QUADRO I - um quarto

QUADRO II - um muro

Interlúdio

QUADRO III - colinas

QUADRO IV - um quarto

Interlúdio

QUADRO V - duas árvores

QUADRO VI - uma rua

QUADRO VII - um quarto

[Apoteose\} Epílogo

\section{PERSONAGENS}

Funcionário do teatro

Uma dama

Um cavalheiro

Um mendigo.

Uma voz feminina.

Um homem velho.

Um contralto

Uma voz de criança

Uma multidão colorida.

Uma mulher verde.

Uma vaca

Um grupo

Um cavaleiro

Dez mulheres

Dez homens

Homem preto

Um rapazinho

Uma rapariga 
Um acendedor de candeeiros

Um tocador de realejo

Um homem jovem

Habitantes de uma casa

Passantes

Operários

Lacaios de libré

Um limpa-chaminés

Vozes nos bastidores

Munique-Murnau 1914. 
[1]

\section{CORTINA VIOLETA}

\section{QUADRO I}

$<$ Faz-se luz>

Fundo liso de um ocre escuro sujo. Chão branco. No meio da parede de fundo, uma pequena porta coberta com uma cortina violeta. Nos cantos sobre o chão, duas palmeiras insignificantes e artificiais. Os bastidores laterais são de um vermelho comum com franjas douradas.

Um funcionário do teatro faz entrar, pela porta com a cortina, uma pequena mesa oval de um pvermelho de cinábrio. Só com esforço ele consegue fazer passar a mesa através da pequena porta: a mesa às vezes aparece, às vezes desaparece ficando presa na cortina. Então o funcionário do teatro aparece no palco e tenta puxar a mesa. Depois sai e esforça-se por a fazer passar empurrando-a. Finalmente a mesa aparece e é quase colocada no centro do palco, do lado direito. Depois o funcionário do teatro traz uma cadeira muito simples, pintada de cor-de-rosa doentio e coloca-a à direita da mesa.

\section{O funcionário do teatro sai.}

Uma dama bastante gorda apresenta-se com um vestido de baile branco, decotado, exuberante, e com um penteado moderno. Ela vem da porta e fica presa na*

cortina pelos cabelos. Ela arranja o penteado e coloca-se não muito longe dos bastidores à esquerda \{bastante atrás $\}$ na ribalta $>$ na pose de uma cantora. A princípio ela está de pé com os olhos baixos. Depois levanta-os lentamente na direcção do público. O seu olhar é um pouco rígido. Devagar os seus olhos dirigem-se para a esquerda, para a direita, para os camarotes, para a galeria. Então a dama volta a baixar os olhos.

\section{PAUSA $(5) *$}

\{Da direita) Um senhor muito elegante e magro, de cartola na cabeça, entra pela porta. A cortina, que ele afasta para o lado, volta a cair <e faz tombar a cartola.> Enfurecido, um pouco à pressa, ele volta a empurrar para o lado a $<$ cortina $>$, <colocando $>$ o chapéu no sítio, e o senhor entra um pouco zangado e embaraçado.

\footnotetext{
* Antações para os actores. Os actores têm total liberdade de interpretação. As excepções são as seguintes: 1. As palavras sublinhadas devem ser pronunciadas de forma expressiva, 2. As palavras com o sinal (!) devem ser pronunciadas muito alto e bruscamente. tal como as sílabas isoladas, marcadas com o mesmo sinal, 3. Os pontos entre as palavras e as sílabas exprimem pausas mais ou menos prolongadas.
* \{Os números designam o tempo em segundos.\}


Descuidadamente ele senta-se na cadeira.

\section{PAUSA (10)}

Senhor (olhando para as unhas)

Eis o começo.

Dama (arranjando o cabelo, olhando para todos os lados, usando um tom muito simples, <voz de peito $>$

Ontem o baluarte caiu.

O peixe está com falta de ar

A porta está a tremer

(A palmeira à direita cai)

Cavalheiro (com um tom de indiferença, de mãos nos bolsos das calças)

Nem uma só vez, nem a mais pequena vez... \{(com grande ênfase) $\}$ vós haveis acreditado $\{$ (atencioso) $\}$ em mim.

Dama (virando a cabeça para a direita)

Ontem, a nova corte entrou em colapso

Cavalheiro (levanta-se, boceja com a mão à frente da boca e anda para cá e para lá junto à ribalta. A luz começa a tremer com toda a força, a vacilar, tornando-se ora vermelha, ora verde.)

Nem a mais pequena vez... vós... haveis... acreditado... em mim.

(mantém-se de pé \{à direita\} à esquerda <do lado direito da dama)

Dama (percorre toda a ribalta e coloca-se à direita junto aos bastidores, com uma voz tremulante)

O oriente é vermelho

(De repente a luz torna-se precisa e de um vermelho-púrpura vivo.

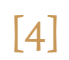

Cavalheiro (acentuando cada sílaba)

* \{Os números designam o tempo em segundos.\} 
O céu \{é verde\} torna-se azul.

( $L u z$ forte $\{$ de um verde venenoso\} azul substitui o vermelho).

\section{PAUSA (3)}

Faz-se escuro de repente $<(5)>$

A seguir, de novo uma luz branca clara e berrante.

Cavalheiro (já lá não está)

Dama (encontra-se de pé no lugar onde estava ao princípio, de olhos baixos, a seguir, como ao princípio, ela corre com os olhos toda a sala (10), e diz com toda a clareza e devagar, como se estivesse a ditar um texto a crianças:

\section{Ontem o baluarte caiu.}

A pouco e pouco escurece. Com a progressiva escuridão, começam a ouvir-se, primeiro de forma indistinta, depois cada vez de forma mais precisa, os barulhos da cidade: o som dos chicotes sobre o dorso de cavalos, buzinas de automóveis, campainhas de eléctricos, os sinos das igrejas <de repente de forma muito clara e audível> soldados a marchar, conversas em voz alta indistinta, um grito de medo <Pausa (5)>, batidelas de relógio, \{choro\}, um realejo que pára de repente, vozes de

comando: "Olhar... à direita!!" Voz estridente de criança que a pouco e pouco se sobrepõe a tudo, como se fosse um vendedor de jornais: O Baluarte! O Baluarte! 5 kopeks!!29 pelo Baluarte! O Baluarte a 5 kopeks!

O baluarte caiu ontem.

Pausa $<(5)>$

Voz de criança (canta muito alto <em completa escuridão> como se fosse um salmo) en-t-o-o-o-a-a-a-a-a.

\section{$[\mathrm{B} 1]$}

29 O autor utiliza a letra "d" (parecida com a letra grega "delta"), e com correspondência à palavra latina "denarius". A letra foi aqui substituída pela palavra "kopek" por ser aquela que melhor serve o ambiente descrito neste quadro. (Boissel, 1998: 222.) e N.T. 
Exemplo aproximado da organização em palco ${ }^{30}$

\section{<Organização de cena:>}

a) ribalta: 3 plantas $<(f, g, h)>$, que poderão estar fixas a uma parede de madeira não muito alta que é de ouro mate.

b) bastidor de fundo: o céu tem de ser bastante vermelho mate, como tijolos corroídos pelo tempo, mas mais escuro. O melhor seria suspendê-lo atrás do bastidor e um pouco afastado dele.

c) Uma pedra com o mendigo

d, e) Rochedos, entre eles o par de namorados. \{Tempo de crinolinas. Do rochedo à direita cresce a flor.\}

$\{f, g, h)$ Flores em primeiro plano\}

Personagens: $<$ (a título de exemplo) $>$

I) Um velho com uma longa barba branca, uma grande careca redonda, rosto redondo, corado, com bonomia. Um comprido cafetã branco, cinto preto de couro. Às costas, um pequeno saco de linho. Na mão direita, um bastão comprido.

2) Um rapaz $\quad\}$

\} Vestidos para a confirmação

3) Uma rapariga\}

4) Um rapaz com uma camisa comprida amarela clara, <calça curta, descalço>

5 -9) Legionários romanos

10) Mendigo coberto de farrapos castanhos

11-12) Par de namorados do tempo das crinolinas.

13) Pessoas com camisas à russa, vermelhas e verdes, todas com cabelos de um louro claro e penteadas à russa. Elas constituem o núcleo do movimento de massas.

\section{[B2]}
14) Um egípcio
15) Uma Lapoa de grandes olhos azuis
16) Uma mulher gorda dos nossos dias
17) \{Um rapaz pálido, de mãos postas para a oração, olha para cima\}<tipo professor com óculos dourados e uma barba compridas

18) Uma mulher velha de luto está sentada e segura no colo um cesto de compras
30 As folhas [B1] e [B2] estão intercaladas e escritas a lápis no Quadro II. (Boissel, 1998: 222.) Trata-se de desenhos de Kandinsky, esboços de cena, concebidos para melhor se visualizar a distribuição dos actores no espaço cénico. (N. T.) 
19) \{Uma dama tipo Império com um ramo de rosas na mão direita\} $<$ Um domador de animais $>$

20) <Uma japonesa de traje tradicional, de braço dado com $>$ uma dama vestida à Idade Média, com touca pontiaguda e um véu pendente que cai sobre o ombro esquerdo e que ela pressiona com a mão direita sobre o coração. Belas pregas!

2I) Um Boiardo

22) Um senhor vestido com um fato elegante actual

23) 4 a 6 homens e mulheres vestidos com maillots de um amarelo estridente (que no fim integram o movimento rodopiante de massas)

24) 4 a 6 homens e mulheres com maillots de um verde estridente

25) Um negro com um adorno de penas na cabeça.

26) Uma criada de quarto de hoje

$<27-28)$ Caixeiro-viajante de hoje.>

Se a área do palco o permitir, ainda se poderão introduzir diversas personagens de hoje, pertencentes a diversos estratos sociais, e elas podem ser colocadas entre as filas de pessoas à frente e atrás.

Os números sublinhados não integrarão o movimento rodopiante, mantendo-se imóveis.

\section{QUADRO II}

Escuro <na sala>. No palco ouvem-se exclamações:

O muro preto! Queremos o muro preto!.. As cúpulas, as cúpulas - Atenção! (ouve-se um tinir parecido com o barulho de vidros em cima de uma bandeja) Olá!!! Oláá-á!!!! Abaixo o sol (rolar abafado) Mais acima as nuvens (toques de sinos profundos e magestosos). O portão fecha-se. Depressa, depressa, depressa! (ouve-se um assobio engraçado e um martelar: lá-lá-lá-lá-lá-lá-lá!) Pum! Pum! etc. Várias vozes em uníssono dão uma ordem brutal) Silêncio!

\section{PAUSA (10)}

De repente fica tudo muito claro. No palco, a todo o comprimento do fundo, eleva-se um muro preto à esquerda, de maneira inesperada $<$ sob a forma de estreitas faixas $>$, sobre uma colina \{verde escura\} violeta e que desce repentinamente. Sobre a colina \{com aspecto de labaredas\} há traços amarelos pontiagudos em sentido ascendente. O muro está coberto de diversas cúpulas 
muito coloridas. Por cima da colina elas são pequenas. O céu <branco, apenas num lugar por cima do muro junto à colina $>$ de um azul escuro muito intenso $<$ sob a forma de um ovo $>,\{\mathrm{com}\}$ nuvens e nuvenzinhas entalhadas que em muitas partes são muito coloridas. <Cúpulas e nuvens constroem por cima do muro uma confusão colorida.> No $<$ meio do $>$ muro um portão baixo, \{pintado de branco\}, \{guarnecido com ferro\} e coberto de ornamentos generosos. Diante do muro, algumas pedras manchadas e partidas. À frente, junto à ribalta, plantas invulgares: quase no meio, à direita e à esquerda dos bastidores laterais <que são pretos e que pendem em pregas pesadas.> Em cima de uma grande pedra ao fundo à esquerda, está sentado um mendigo coberto de farrapos, com muletas e com ar submisso. À direita, entre 2 pedras brancas, elevadas e pontiagudas, < (uma rosada, a outra esverdeada) $>$, um par de namorados: ela põe as mãos sobre os ombros dele; \{e\} ele segura-a pelo pescoço com a mão direita, com a mão esquerda, enlaça-a pela cintura. Ambos - do tempo das crinolinas.

De repente o portão abre-se completamente. Um grande grupo de pessoas aparece a correr: de todas as épocas, idades, cores, caracteres.

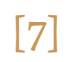

Alguns têm sapatos de madeira, outros trazem nas mãos pequenas campainhas, guizos, outros assobiam \{etc.\}.

Ao saírem pelo portão, ouve-se logo \{o som musical\} o martelar dos sapatos de madeira, <ora a compasso, ora em confusão>, a seguir apenas os guizos. Em breve muitos assobiam. <Outros tocam campainhas. $>$ As pessoas correm <em círculo> palco fora e às voltas: primeiro todos, depois apenas os que têm sapatos de madeira, depois os que trazem os guizos, etc., sempre em combinatórias. Depois todos juntos outra vez e a pouco e pouco cada um encontra o seu lugar.*

\section{PAUSA $(15-20)$}

$<$ Uma $\{$ luz violeta\} escura $<$ feixe de luz violeta $>$ atravessa 3 vezes o palco $<$ da esquerda para a direita>.

Uma trombeta e um tambor atrás do palco <ao mesmo tempo>: Pum! Catrapum!

\section{PAUSA (5)}

* Durante o tempo em que os sapatos de madeira martelam, a luz torna-se violeta. Com o soar das campainhas, ela torna-se cor-de-rosa, ao som dos guizos, ela fica azul claro, com os assobios - ela torna-se verde. As luzes agem em conjunto por combinatórias <de forma alternada>. Quando cessam os sons, a luz fica branca. 
Uma luz vermelho-claro \{em tom cinábrico\} passa rapidamente, ela repete-se de maneira mais prolongada (3).

Trombeta: Pum!
31 autor parece confundir "cortar" com "soltar". Boissel, 1998: 230.)

\section{PAUSA (5)}

A luz \{torna-se\} azul escura.

Tambor: Catrapum! Catrapum! Catrapum! etc. (sempre cada vez mais fraco $<$ e a luz cada vez mais branca>).

A partir deste som e desta luz cresce a voz do mendigo: (quente, lenta, às vezes subindo no ar inesperadamente,

às vezes baixando de repente, em certos momentos quase gritada, por fim nasalada, sem expressão.):

"Coxo e sem muletas,

Não me posso mexer.

(em pranto) Ainda não nasci

A força perdi.

<(com modulações, como \{harmónicos\} um glissando de violoncelo>

O radioso sol não vejo.

A luz, como a apalpo?

(profunda e solene) Ainda não nasci.

O rosto perdi.

(cortante, ${ }^{31}$ algo apressado)

Em abandono me arruíno

(muito arrastado)

É para as massas que vivo

(nasalado) Ainda não nascidos

Estamos como perdidos.

\section{PAUSA (10)}

Vozes isoladas de diversos lados: 
Uma voz média: Cheia... Completa...

Uma voz baixa: Pro-fundi-dade.

\section{PAUSA}

Uma voz média insonora: Sem som.

Pausa

O mendigo $\{$ (como antes) $\}$ (arrastado)

Coxo e sem muletas...

(interrompe de repente)

Uma voz aguda de mulher: Zumbido \{a tender para\} muito aguçado.

Diversas vozes de criança (rápidas) Quem? Constrói? Quem constrói? Quem constrói? Quem consatrói?

Voz de contralto: Rugido tenso \{estremecente\}

Crianças (cortantes e audíveis) Sem! Som!

Sem! Tom!

Tenor (alto, divertido): Saudável viver.

O Mendigo (como antes)

Eu não me consigo mexer.

Baixo (muito baixo): E o profundo ardor.

Trombeta (por detrás do palco): ta-ta-ra-ta!

Ta-ta-ra-ta-a-a-a!

Baixo (muito baixo) Palavra escondida.

Todos (muito arrastado, com suavidade, sem acentuar a pergunta)

Quem o construiu? .... (3) 
$<$ A luz torna-se conzenta, muito difusa (5)>

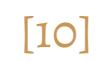

Atrás à direita < precipita-se de cima um estreito feixe de luz vermelha, qualquer coisa perturba as pessoas em baixo, o feixe de luz vai-se tornando cada vez mais claro e> nasce um forte movimento: um grupo de entre o conjunto das pessoas move-se como se fosse um barco em plena tempestade, atirado de um lado para o outro. Alguns tentam esgueirar-se e sair do meio do amontoado, outros são expulsos e voltam de novo para lá. A pouco e pouco, esta movimentação vai na direcção da esquerta. $<$ O feixe de luz segue o amontoado.> As pessoas que estão atrás são abrangidas por ele. $\mathrm{O}<$ feixe de luz vai alargando o seu raio de acção e> o amontoado cresce e rola para a esquerda dos bastidores laterais, em direcção à frente. $O$ feixe de luz vai abrangendo cada vez mais pessoas, é direccionado para trás, até chegar ao meio. As pessoas restantes não olham à sua volta, embora sejam arrebatadas como um pedacinho de madeira pelo caudal de luz: \{costas, lados, rosto.\} \{Aqui e acolá levantam-se braços, cabeças são atiradas para trás, e assim\} Todo este movimento continua com braços pendentes, como criado por pessoas adormecidas.

No momento em que se fazem ouvir os primeiros sons de uma voz de mulher, tudo permanece como petrificado

à esquerda, onde o par de namorados se encontra (voz profunda e bela) \{as interrupções são assinaladas por pontos\}.

A luz torna-se $<$ de repente $>$ tão verde escura quanto possível.

\{Eternamente\} Aquilo que é passado... permanece

e tudo \{será cura\} se ligará e renascerá,

tudo o que... se rom-peu... e... ass-im

$<$ (rapidamente) > o que está murcho florescerá.

$<$ (Os participantes no movimento sentam-se devagar no chão

e \{ficam\} encolhidos e sem se mexerem com as cabeças e os braços pendentes \{sentam-se em silêncio\}).>

$\mathbf{O}$ mendigo (em tom nasalado)

Ainda não nascidos

Estamos como perdidos.

A voz de mulher (como acima): 
Sem coerção e se-em no-me

A unidadeeee ééééé a verdadeira semente

E-e-e-e-e numa só! Transss-fi-ggggu-rrra-daaa fonte!..
* Todos estes sons estão associados a correspondentes e diferentes desenhos de luz.

$<$ Voz de criança $>$ (rápida)

Onde é o princípio?... Onde é o fim?

Os sapatos de madeira: toc-toc-toc-toc!

As campainhas: Tlim! Tlim!... Tlim! Tlim!

Os assobios: Pfiu! Pfiu...

A trombeta $<$ (como acima) $>$ ta-ra-ta-a-a-a!

O tambor <(como acima, mas uma oitava abaixo)>

Pum!* \{como acima o som do tambor mais profundo\}

\section{$[11 A]$}

O homem velho perto da ribalta (com uma voz tremulante):

O mistério. O grande, o doce mistério. O mistério inexprimível. O mistério não sentido. O mistério, o grande, o doce mistério da barca, da barca preta, da barca na água, da barca preta, que não receia um único peixe. Gentes amáveis, amáveis gentes, gentes amadas, amadas de modo insignificante. Pobres

gentes! Pobres!! Pobres!!! O fio que prende a barca. O fio, o pobre fiozinho. Pobre!! Pobre fiozinho. Água verde, verde clara, verde leitosa esmeralda. E por cima dela a barca preta presa a um fio. E por cima da barca um céu verde oliva, verde oliva sujo, verde oliva da cor da sujidade da rua. Uma pequena mancha branca, a única, mesmo a única, a única de todas. A pobre manchinha branca. A manchita branca, a única, a única. E a...

O homem velho (a luz de um azul muito escuro - mal se pode ver alguma coisa) à frente, primeiro com voz mecânica, a seguir inesperadamente viva) O mistério, o grande. O in exprimível. O não sentido. (Luz branca) $\mathrm{O}$ mistério, o grande mistério da barca, da barca preta (luz negra), da barca na água, da barca preta que não receia um único peixe, que não receia um único (a luz azul clara turquesa). (perguntando) Gentes? (de forma acentuada) Gentes! (de forma mecânica)... [?] (com clareza) O fio que prende a barca (luz cor-de-rosa). O fio, o pobre fiozinho (de forma expressiva). Pobrezinho! Pobre fiozinho! Água verde (luz verde leitosa), verde clara (a luz mais clara), verde leitosa esmeralda (a luz verde esmeralda). E por cima dela a barca preta presa a um fio (a luz branca). E por cima da barca um 
céu verde oliva, verde oliva sujo, verde oliva da cor da sujidade da rua. Uma pequena mancha branca (de modo expressivo), a única, mesmo a única, a única de todas. A pobre manchinha branca. A manchita branca, a única, a única. A silenciosa mancha branca (luz mais clara). A manchita branca, a única (luz ainda mais clara), mesmo a única. E todos os

\section{[11A VERSO]}

peixes < a luz fica verde >, que não perturbam nem são perturbados. $<$ (Com muita clareza) $>$ Em fila. $<$ (A luz torna-se violeta $>$ ) Em fila $<$ ( a luz torna-se amarela $>$ ) $<$ (em tom baixo $>$ ) Pobres, pobres peixes (a luz fica verde). $<($ em voz alta $>$ ) Pobres, pobres gentes (a luz fica azul).> Ah! Que pobres, que pobres. $<$ (com muita clareza) $>$ Em fila.

$<$ A luz vai baixando lenta e cada vez mais profundamente.>

Vozes isoladas $<$ (sob diferentes modos) $>$ (A luz \{de um azul muito profundo, adequa-se ao que é dito\}<fica branca quando há gritos e logo a seguir de novo azul profundo>).

$<22 *$ Uma voz média $>$ Setenta toneladas! Setenta? Inconcebível. Espantoso!

$<21$. (Baixo) > Com a ajuda da corda, claro! Antes, porém, a sua elasticidade tem de ser experimentada com exactidão.

<a partir de 24. > (muito alto <e por trás, de modo muito barulhento >) Medir (!)

Medir! Muito simplesmente medir com exactidão.

Do modo mais penoso possível!

<a partir de 13. (Tenor) > E além de tudo o mais, isso não é seguro.

$<$ a partir de 23. (num tom muito mais baixo) > Não determinado?

<a partir de 13.> Não de todo! Essa é justamente toda a piada!

<a partir de 23. > Não determinado mesmo?

<a partir de 13.> Ora! Está a ver! É sempre assim: primeiro fazemos uma pergunta e depois não acreditamos nela.
* Os números correspondem ao plano de construção do quadro. 
\{6.\} 2. 45 Kopeks? Fora de questão!

7. Se, porém, extrairmos a raíz de 6/17 avos...

\{3.\} < a partir de 24.) (muito alto) Medir! Do modo mais penoso possível!> $\{$ (muito alto)\}

$<17 .>$ Nunca se deve puxar a tromba ao elefante!!

\section{[11B]}

8. $<$ (Baixo) $>$ Oh, sim! Sempre em frente.

9. De acordo com a sua opinião há muitas divisões aqui...

8. São possíveis? Estou convencido disso. E elas não são apenas possíveis comomais do que certas.

\{1\} 22. A sério? Setenta toneladas? Incrível!

$\{10\} 26 .<$ (com vivacidade e bastante alto) $>$ Sim, sim! Uma garota simpática adorável. Mas foi assustador: durou quase 48 horas.

Sofrimentos absolutamente horríveis. O marido dela

\{estava como\} quase ia ficando louco.

\{1\} 22. See-tenta toneladas! Disso eu gosto!

$\{11\}$ 27. Não, perdão! O primeiro era afinal melhor, muito, muito melhor. Esta flor!

\{12\} 26. Oito rublos, acho?

$\{11\}$ 27. Sim, sim! E apenas oito rublos a garrafa.

$\{3\}$ a partir de 24 . (muito alto) Não é preciso falar disto em voz alta!!

$\{13\}$ 11. < (Voz de mulher) > Não! Não! Eu já não acredito em ti!

\{19. Espancar apenas com o bastão. Patético.

Isso foi uma boa lição.\}

$<22$. Disso eu gosto $>$

4. (Voz de contralto \{à frente à direita junto à ribalta\} < (A luz muito vermelha profunda) $>$ Rochedos amarelo claros. Só os cumes vermelhos. Ver-meee-lho como... oh!! Ver-meee-lho. (ela chora com amargura) oh, tão vermelho, tão vermelho, tão vermelho, 
Oh, tão vermelho! A-a-a-ah! Não! Não! (em soluços) Tão

vermelho, tão vermelho, tão vermelho, tãã-o ver-meee-lho.

\{1\} 22. Voz Disso eu gosto!

$<$ (A luz amarelo-limão).>

3. Voz de criança (entusiasmada, quase sem fôlego, apressada)

O amarelo, o amarelo - caiu em pedaços. Em

pedacinhos. Assim de repente! Pumba! E já está!

Esmaguei-o completamente com o pé.

$<$ (A luz branca) > Tão completamente, tão

completamente.

E o vermelho ficou suspenso no ar. Ficou suspenso!

Quero agarrá-lo - mas não consigo.

E tudo ficou completamente vermelho, completamente.

Quero agarrá-lo - mas não consigo.

$<$ a partir de 24. $>$ (Voz média de homem) < A luz vai-se tornando mate) $>$ O cas-ta-nho e-le-va-se! Espezinhá-lo. O verde nãã-o!

Poo-sso contar coo-m is-soo!

\{1\} 22. Voz Disso eu gosto!

A luz torna-se branca estridente.

\section{PAUSA (5)}

Atrás num turbilhão passa a correr, da esquerda para a direita, um bando de figuras brancas $<$ (com roupas esvoaçantes) $>$ e rosotos brancos.

$<$ Trombeta ta-ra-ta-ta-ta

\section{PAUSA (5)}

Tambor (abafado) Pum... Pum - Pum (5)> 
À direita, mesmo junto à ribalta, aparece uma figura de mulher verde-estridente, muito grande, magra. $O$ seu rosto é de um verde muito claro. \{Os grandes olhos estão imóveis.\} Ela caminha muito devagar ao longo da ribalta e $\{$ olha\}, o rosto voltado para os espectadores. Os seus < grandes $>$ olhos continuam imóveis.

Pouco depois faz-se escuro no fundo do palco. A escuridão estende-se cada vez mais em direcção à ribalta.

A voz do mendigo soa penetrante e nasalada:

Já estamos perdidos.

Escurece completamente. Apenas a figura verde continua a estar iluminada num tom claro.

\section{Escuridão}

\section{$[\mathrm{Cl}]$}

\section{Interlúdio (antes do QUADRO III)}

Escuro (5). No canto superior direito surge um pontinho vermelho mínimo que a pouco e pouco vai adquirindo força e tamanho. Do canto esquerdo inferior estende-se na sua direcção um feixe de luz negra $\{$ branca $\}<$ (o branco será possível?)>. O vermelho dirige-se para o centro e constrói um grande círculo. $\mathrm{O}$ \{branco\} negro foge para cima à direita. À direita em baixo movimenta-se aos saltos uma forma oval azul clara. No meio, à direita do vermelho, surge um círculo amarelo amachucado e desloca-se rapidamente para cima, escondendo-se no canto \{direito\} esquerdo. Isto repete-se tr es vezes. A forma oval azul torna-se esverdeada e vira-se devagar por cima do vermelho. $\mathrm{O}\{$ branco\} preto cai em direcção ao chão e leva consigo o amarelo.

$O$ vermelho retrai-se e recebe uma borda azul. Toda uma série de manchas de variadas cores e variadas formas agrupa-se no centro.

A borda azul recebe <ela própria > uma borda amarela estridente.

De repente escuro (3).

O pontinho vermelho, em cima à direita, corre rapidamente para o centro. A grande velocidade o feixe de luz \{branca\} negra repete-se.

Escuro. (3)

O pontinho vermelho no centro. Ele cresce muito rapidamente e inunda toda a superfície.

Trombeta e tambor Pum! Catrapum! 


\section{Escuridão}

[13]

\section{QUADRO III}

$<$ Começa por estar escuro; \{a seguir começa a aparecer luz branca\}, depois fica amarelo; a luz amarela vai ficando cada vez mais clara e quase chega a atingir o branco: uma névoa amarelada parece permanecer suspensa no ar. Atrás à direita, encontra-se <o relevo[?]> de uma alta colina rochosa, cujo cume <e em direcção à direita > deixou de ser visível <e se alarga para diante. ${ }^{*}$ De cima qualquer coisa que faz lembrar uma queda de água em curvas bruscas. Ela é de um vermelho mate. Queda de água - prateada com traços pretos < perpendiculares $>$ \{que se assemelham a água. Por cima da colina, píncaros verde estridente de aspecto ornamental. Aqui e ali, eles parecem crescer a partir dos contornos superiores da colina, e destacam-se claramente contra o céu negro, hastes brancas cujo desenho às vezes se assemelha a pinheiros mortos. No céu, ordenam-se de maneira um pouco esquemática pequenas nuvens encaracoladas. À direita, mais perto da ribalta, há pedaços lascados da colina, tão pontiagudos como a própria colina angulosa, dura. \{Em direcção à esquerda a colina torna-se suave e dilui-se em formas ondulantes.\} À esquerda, perto da ribalta, aparece uma forma redonda e rechonchuda que faz lembrar uma grande pedra branca. Sobre ela encontra-se uma vaca de cabeça muito grande, com o pescoço estendido e a boca aberta. O seu úbere é azulado esverdeado, grosso e pesado

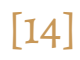

e pende em direcção ao chão. \{Bem à frente e à direita há um grupo de $<10 \mathrm{a}$ $12>$ homens e mulheres que em < grande> parte estão de pé, mas que também em parte estão sentados em cima de pedras brancas redondas com manchas. ** (estas pedras não são de um branco tão estridente como a perdra grande à esquerda) $\}^{32}$ Os fatos são parecidos com os trajes regionais russos, muito coloridos: amarelo estridente, verde, vermelho, azul, com manchas, ornamentados, etc. \{Todo o quadro está como que inserido numa moldura bastante larga, que possui no exterior linhas prateadas e que no interior é vermelha brilhante (carmim). Em cima há um triângulo: truncado no topo e de forma oblíqua: no meio <prateado>, de superfície irregular, de modo que a prata brilha fortemente sobre ele. Nos cantos superiores, à direita e à esquerda, há
* [Este acrescento encontra-se na margem esquerda do manuscrito.] $\mathrm{Na}$ direcção da esquerda a colina corre ondulante e desaparece por detrás dos bastidores. (Boissel, 1998: 242.)

* Alguns têm posições muito melancólicas, alguns são de madeira, alguns orgulhosos, etc. Todos eles se parecem com bonecos de madeira pintados.

32 [Nas costas da página. [C1] existe uma variante desta parte do texto:] Fundo liso preto.

À esquerda, em frente a uma grande forma de ovo, encontra-se uma grande vaca desajeitada e vermelha, com um úbere pesado e azulado.

À direita, 10 a 15 homens e mulheres. (Boissel, 1998: 242.) 
cortinas curtas, <em veludo vermelho $>$ barato com franjas e borlas douradas.\} $<$ O chão branco $>$ A luz pisca muitas vezes.

\section{$<$ PAUSA (3) $>$}

Por detrás do palco ouve-se um violino a tocar em escala lenta: \{As n[otas] mais altas, quanto mais altas forem, mais lentas; as \{notas\} tons superiores

\section{$[15]$}

possuem um desenho infinitamente longo. Isto acontece três vezes.

Logo a seguir

Coro (muito divertido, em modo de dança)

Eh! Quão solene a parede caiu!

Eh! Em pedaços seu estrondo se ouviu!

(repete-se três vezes; com a palavra Eh!, todos - \{mesmo os tristes\} batem $<$ mecanicamente> com o pé)

De repente faz-se escuro. (5) A seguir tudo recomeça desde o princípio: $<$ A luz amarela [a tremeluzir\}, violino (uma vez); luz a tremeluzir> e o coro (uma vez). Tudo pára de repente. Da frente, surge um feixe de luz violeta que começa por varrer o coro, a seguir: o canto superior esquerdo (5), o meio, nuvenzinhas isoladas, o canto superior direito (3), de repente, ele incide sobre a vaca que ele varre de uma ponta à outra. Durante este processo de iluminação, ouvimos em sons nasalados uma flauta pastoril primitiva - melancólica, arrastada. Luz e som param ao mesmo tempo.

\section{PAUSA (5)}

Sons profundos, pensativos de fagote:

Brom... brom... brom... ououououou... Uma luz vermelha suave \{aparece do meio\} do centro das decorações do fundo que se projecta na sala de espectáculo, errando de lugar em lugar-<em breve aos saltos, em breve devagar, de forma calma.> Uma voz humana profunda

\section{[16]}

repete caricaturando os sons do fagote. A seguir regressa a luz violeta e a seguir agem em conjunto: Ambas as luzes, ambos os instrumentos, <ora ao 
mesmo tempo, ora desencontrados.> (10)

\section{PAUSA (10)}

A voz humana: Brom... brom... brom... ououououou...

No canto superior esquerdo aparece um enorme sol dourado (com a superfície rugosa e brilho dourado), que só é visível ao público a 2/3 da sua grandeza. Ele produz uma luz $<$ (como um projector) $>$ violenta amarelo-limão sobre o coro, \{que por isso\}.

Logo a seguir

Coro Eh! Quão solene a parede caiu! Eh! Em pedaços seu estrondo se ouviu!

(A vaca é iluminada de frente por uma luz cor-de-rosa, de tal modo que a sua gigantesca sombra projecta-se no fundo. A sombra adquire através desta luz um brilho glorioso cor-de-rosa.)

A vaca: muge de forma breve e alto.

Coro: Eh! Em vão todo o belo rio se dissolve!

Eh! Vem aí uma nova fonte!

(de modo espaçado)

Eh! Vem - aí - uma - nova fonte!

(para cada sílaba o coro bate com o pé).

\section{$[16 \mathrm{~A}]$}

A partir da frente, um grande feixe de luz < bastante > oval, verde estridente, tóxico, é lançado sobre a grande colina, ligando os troncos das pessoas ao fundo.

A vaca muge de forma mais prolongada e mais alto.

Seguindo-se uns aos outros, breves, rápidos \{com\} um violino < (faz trilos a partir de uma nota alta) $>$, uma flauta $<$ (trila sobre uma nota baixa) $>$, um fagote $<$ (uma nota muito aguda, muito baixa, média - longamente)>, uma voz. Por um momento escuro. (2) Em seguida, rapidamente as luzes, umas atrás das outras: violeta, vermelho (na sala de espectáculo), cor-de-rosa, amarelo, verde. 
Coro (mais alto, mais rápido, mais intrusivo, muito animado, com batimentos)

Homens Eh! Já nele acreditam e de forma modesta!

\section{PAUSA (3)}

Mulheres (sons muito agudos) Eh! Nem sempre é eterna a floresta!

A vaca (muge ininterruptamente e de fazer partir o coração)

\section{Coro (grita)}

Eh! A parede! O estrondo! O rio! A fonte!

A floresta!

Eh! Em breve! Em breve! Em breve!

(primeiro como um espasmo com pausas muito curtas. A seguir, sempre cada vez mais depressa, uns

\section{$[16 \mathrm{~B}]$}

atrás dos outros, algumas vozes gemem. $<$ Todas as luzes se mostram $<$ na sala à excepção do vermelho> e permanecem fixas.>

O mugido da vaca acontece. Aqui e ali ouvem-se mugidos ou o coro sozinho, $<$ (ora homens, ora mulheres) $>$. A seguir de novo tudo misturado. Enquanto isto acontece, as luzes baixam e desaparecem devagar. A luz geral torna-se azul, cada vez mais azul. Primeiro bruscamente e depois de modo uniforme o barulho retrai-se.

A vaca muge de forma deplorável (como se lhe tivesse levado o bezerro). A pouco e pouco faz-se escuro. Apenas no meio da ribalta se vê uma pequena fonte. Ela é iluminada de cima com uma luz branca. Ao fundo surge um arco-íris. De resto tudo escuro.

Vozes de baixos Eh! Eh! Eh!

\section{PAUSA (3)}

A vaca muge de forma miserável 
Vozes de baixos (cheias de mistério)

Eh! Eh! Eh!

(O arco-íris desaparece).

\section{PAUSA (3)}

Vozes de baixos (cheias de mistério)

Eh! Eh! Eh!

A vaca (muge < de forma breve > alto e d epartir o coração).

\section{PAUSA $\{3\}(5)$}

Escuro total.

\section{PAUSA (3)}

Vozes de baixos <(em uníssono e secas, logo cortadas)>

Eh! Eh! Eh!

\section{QUADRO IV}

Decoração como no Quadro I, com a diferença de que agora a palmeira da esquerda está virada, enquanto a palmeira à direita se eleva, bastante afastada do canto, e longe o suficiente da parede lateral, ela está de pé sem motivação.

O cavalheiro (está sentado, o braço esquerdo encostado e pendendo por cima do encosto da cadeira, um pouco esticado para o lado, o braço direito está pousado em cima da mesa, na respectiva mão um limão)

A dama (está de pé à esquerda, em guarda como um soldado)

$<$ Em breve $>$ (após 5) a cortina violeta balança-se como batida pelo vento para cá e para lá. Depois esvoaça como uma vela.

O cavalheiro (com cortesia) Querida senhora!... Querida senhora!......

Peço perdão pela minha insistên 
cia! ...

\section{PAUSA (3)}

O cavalheiro Querida Senhora!... \{grita\} (beixinho)

Querida senhora! \{!!\}

A dama (tensa) Não é por nada!... Oh, não! (muito expressiva) oh! não! (a seguir a uma curta pausa, ela vira <algumas vezes> a cabeça para a direita e para a esquerda $<$ devagar $>$ como que a dizer não.

O cavalheiro (poisa o limão em cima da mesinha. O limão começa a rolar, ele volta outra vez a colocá-lo com cuidado e com toda a atençãojunto à borda da mesa que está do lado oposto, a seguir coloca a cartola debaixo da cadeira e limpa o suor da testa com o lenço, que é azul claro, e coloca-o depois na borda da mesa junto ao limão. A seguir pega no limão e põe-no perto de si. De seguida pega no lenço e coloca-o no meio da mesa, <perto do limão.> Depois pega no lenço com a mão direita, com a esquerda peça no limão e abre os braços na direcção do público. Depois aproxima-os do rosto e olha para eles com toda a atenção. A seguir volta a mostrá-los ao público).

\section{[19]}

Atrás do palco a tuba -Ta-ta-ra-ta! Ta-ta-ra-ta! O violino faz uma escala em pizzicato.

A cortina é soprada do quarto, balança-se um pouco e cai direita.

A dama (com as mãos apertadas contra o peito, muito emocionada, com interrupções e uma voz por vezes entrecortada, faz voz de peito fortemente sublinhada).

Ontem... ontem no... baile.

$<$ (A cortina inchada como um balão irrompe sala adentro.)>

O cavalheiro < (enfia o lenço no bolso das calças $>$, pega na cartola, atira o limão pela porta que está debaixo da cortina, que cai imediatamente, <retira o lenço do bolso $>$, limpa com ele o topo da cartola [com o lenço\}, <volta a enfiar o lenço no bolso, põe-se de pé, (5) apoia-se com a mão \{esquerda\} direita na borda 
da cadeira, com a mão esquerda segura no chapéu pela borda exterior e pressiona-o com a coxa. Uma voz de baixo profundo, brusca, imperiosa)

O baile!!!

A dama (quase implorando)

Ontem, ontem, ontem, ontem... ontem no, no, no baile.

\section{[20]}

O cavalheiro pega na cartola com ambas as mãos por deytrás das costas, balaceia-se nas pontas dos pés, com desdém)

Ah!

Atrás do palco, <feio>, de maneira brusca, em uníssono, numa só nota, como no fim do Quadro III

Eh! Eh! Eh!

A dama (convicta, sincera e com simplicidade, com voz interior)

O senhor sabe, cada ser tem no coração... Está a compreender! Eu não sou capaz de me exprimir bem, mas é assim que se diz - não é verdade?

\{Mas diz-se assim?\} Pode dizer-se assim? Não sei como me poderia exprimir de outra maneira! Mas estou a dizer a verdade! A sério! Como poderia eu dizer isto de outra maneira? Cada ser tem no coração... (após uma curta pausa, pensativa) Parece estranho e quase ridículo (embaraçada) Expresso-me como uma colegial. Mas não sei-como é que eu hei-de... Sim! Não! Não consigo dizê-lo de outra maneira!

\section{[21]}

O cavalheiro Querida senhora, mas continue a falar!

A dama (de novo como um soldado em guarda, mantém-se calada)

O cavalheiro (também ele fica rígido, depois de repente começa a tremer)

Querida senhora!... Querida senhora! Ah! Por amor de Deus! Fale lá! (Grita como possesso) Fale! Com os diabos...! (amedrontado, em tom baixo) Estive quase a cometer um pecado. (suplicante) Querida senhora! Peço-l he, peço-lhe, por favor!

(De repente faz-se escuro) ${ }^{33}$

\{Quadro de Interlúdio\}

$<$ Interlúdio $>$
33 [O autor interrompe aqui a página, introduz o interlúdio correspondente (à página 21a) e regressas depois à página 21] 


\section{Interlúdio (antes do QUADRO V)}

Sobre uma tela branca esticada uma mancha preta esborrachada no centro, que em breve ora se transforma num verdadeiro círculo, ora volta à forma original. Do canto inferior direito nasce um traço preto em direcção ao canto esquerdo superior. Repete-se este movimento da esquerda para a direita.

A mancha preta desaparece.

$<$ Em breve > ambos os traços estremecem, <em breve > tornam-se indistintos, e voltam a tornar-se nítidos.

Enquanto eles se mantiverem indistintos, a mancha preta volta a aparecer, mas também ela indistinta.

Tudo desaparece (2)

De novo os dois traços muito acentuados. (3)

A seguir eles movem-se como raios de rodas, sempre cada vez pais depressa, até se fundirem \{derreterem\} ambos numa mancha.

Imediatamente aparece um caleidoscópio (10).

Escuro (10)

Atrás do palco uma explosão.

Pausa (3)

\{Rapidamente e a seguir uns aos outros, sons de tambor\}

Pancadas de tambor desaustinadas (5)

Assobios agudos atrás do palco.

\section{PAUSA (3)}

\section{Voz de criança (como no QUADRO I)}

Ele co-co-co-la-la-la-psou-psou-psou-psou

\section{PAUSA (3)}

Flauta pastoril repete as notas $<$ nasaladas $>$ da voz de criança.

Atrás do palco, um cavalo a galope.

A trombeta repete o mesmo motivo num tom muito baixo.

$$
[21]^{34}
$$




\section{QUADRO V}

À direita bem à frente, uma tenra bétula, à esquerda bem atrás um enorme abeto $<$ com a forma de pirâmide $>$ \{cujos ramos inferiores pendem junto ao chão\}. Os seus ramos inferiores pendem junto ao chão. Céu limpo vermelho zarcão. <Cortinas laterais, estreitas, lisas, azuis.> Um gigantesco pássaro amarelo (semelhante a um pelicano) com uma cauda verde vôa do meio do palco e desaparece devagar no céu. Diversos instrumentos de sopro tocam de forma desencontrada (música

\section{[22]}

de caserna). A tuba soa a uma espécie de acompanhamento Ta-ta-ra-ta! Ta-ta-ra-ta!

Um cavaleiro cavalga $<$ na diagonal $>$ palco fora - da bétula até ao abeto, atrás do qual desaparece. (O cavalo é branco e malhado; o cavaleiro tem um rosto todo branco, cabelo preto muito curto penteado para a frente \{escovado\}; veste uma camisa larga verde estridente, por cima da qual tem uma toga amarela baça, oernas nuas, muito brancas, colados aos pés, sapatos rasos vermelhos. A garupa do cavalo está coberta por um pano ricamente bordado com $<$ grandes $>$ motivos \{florais\} de flores e animais. O pano tem a forma de uma cauda.)

\section{PAUSA (5)}

Dez mulheres cobertas com véus azuis (vão < umas atrás das outras > fazem o mesmo caminho com passos teatrais. As suas vestes têm pregas abundantes, as < muitas> pregas são finas e tesas; os [rostos\} as cabeças também estão cobertas, de tal modo que os rostos não se vêem.)

A tuba (a solo) Ta-ta-ra-ta! Ta-ta-ra-ta!

\section{[23]}

As mulheres (gritam palavras incompreensíveis atrás do placo em diferentes vozes; de repente uma ri em voz alta).

\section{PAUSA (5)}


A bétula (estremece)*

\section{PAUSA (5)}

Voz de criança atrás do palco (soprano agudo), forte e brusca:

d-e-e-e....

Thek (!) -la (!)

Dez homens (de maillots vermelho escuro, com manchas, rostos <escondidos $>$ fazem em cima de andas <altas $>$ o mesmo caminho <e desaparecem por detrás do abeto>. Na cabeça têm chapéus chapéus amarelos, brilhantes, semelhantes a bolas; as andas martelam o chão com barulho)

A tuba Ta-ta-ra-ta! Ta-ta-ra-ta!

\section{PAUSA (5)}

De detrás do abeto aparece um homem \{está vestido à árabe, também é só isso\}, a sua vestimenta árabe, tal como o rosto, muito escuros, de tal modo que ele se parece com uma silhueta. Ele acena com o dedo, olha rapidamente para todos [?] os lados e volta a acenar).

Um rapaz e uma rapariga (vestidos à Verão, seguem rapidamente pelo memso caminho do homem de preto).

Os instrumentos de sopro em conjunto (tocam de maneira festiva, <com muito sentimento>, qualquer coisa como um salmo.)

\section{$[24]$}

O homem de preto <ao som desta música> pega nas crianças ao colo e segue com passos muito pesados < difíceis> em direcção à ribalta.

(As mulheres azuis aparecem hesitantes e caminham como se fossem sonâmbulas. Elas formam um círculo à volta do homem.) (Os homens das andas chegam com muito barulho e formam um círculo atrás das mulheres. $\mathrm{O}$ grupo todo \{ou quase todo\} aproxima-se da bétula). Por detrás do abeto, o cavaleiro inclina-se por cima do pescoço do cavalo eolha para o público.

A música emudece. O quadro permanece imóvel. (10)
* [O texto que se segue termina com a palavra "Thekla" e encontra-se no verso da pág. 22]

Em relação à pág. 23, ouve-se atrás do palco uma voz de homem (tenor)

muito forte e acentuada:

La-a-auren-ti-i-i-ius

La-a (!) -ouviiiii-dooos

Voz de mulher (Contralto) atrás do palco igualmente forte e acentuada Vi-i-i (!) -i (!!) ra (!!!) gem O teu-eu-eu-eu ou (!) -vi (!!) do 
A pouco e pouco faz-se escuro.

\section{QUADRO VI}

\{Primeiro\} Escuro. Uma voz insolente de rapaz canta

muito alto:

"A voar vem um pássaro."

Uma voz de homem: Não! Não! Pára! (O canto silencia-se) Tem cuidado! Calate! (Ouve-se o violino tocar longa e meticulosamente; a seguir ele toca a dança popular "a Kamarinskaja"35 que, de repente, é interrompida.

\section{PAUSA (5)}

\section{$[24 \mathrm{~A}]$}

Em completa escuridão dois coros falam em recitativo de maneira muito simples e cordial:

Homens Não olhem para as árvores. Não olhem para as árvores no ar. Mas olhem para as árvores na água. Vejam como elas baloiçam, fazendo arcos, curvas, ziguezagueando os seus troncos, ramos, galhos, galhinhos e que confusão está a acontecer.

Mulheres Não olhem para a barca, e também não olhem para as pessoas na barca, não olhem para os remos. Olhem para o montículo de água que se formou com uma remadela. Basta que olhem apenas para esse montículo: vejam como esses flancos - ora lisos, ora agitados, escalam esses lado como barrancos, como essas margens, quais ranhuras e cristas, estão cheias de cor, e são \{macias\} flexíveis e afiadas, e são obstinadas (parecem irreprimíveis e logo a seguir desaparecem), e são macias (e não se deixam esmagar, apenas furar com o dedo). E por cima do montículo de água o cume é um todo de pulverizações

\section{[24B]}

e estas ora se confundem com o montículo, ora crescem a partir dele, ora permanecem suspensas no ar acima dele. 
Homens Não olhem para a barca. Não olhem para a água azul profunda, verde profunda, não olhem para a água branca, rosa, cerúlea, violeta, vermelha, preta, lilás, oliva, castanha. Não olhem para a água plena nem para a água vazia. Olhem apenas para a água verde estridente, que gostaria de ser afagada, que gostaríamos de lamber, na qual existe o desejo de enfiarmos a mão, que gostaríamos de beber, que deveria ser trazida para casa, com a qual respirar se torna possível, através da qual sentimos no peito a juventude, a frescura, a transparência, a luminosidade, a calma, o divertimento, a segurança, que cheira a eternidade que só é visível debaixo da barca que é tão leve, tão casta, que é impossível compreender e acreditar que ela possa suster a barca.

Mulheres Não olhem para esse homem. Olhem para as suas pernas, olhem antes para as plantas dos seus pés e como cada uma delas se curva, à sua maneira e vôa no ar e, à sua maneira,

\section{[24B]}

cada uma delas atinge a base do calcanhar, se apoia em direcção ao chão e de novo à sua maneira, se curva e volta a voar no ar. \{Não olhem para os troncos mas para o que há entre eles, olhem para o que está debaixo da mesa, para o que está em cima do telhado, para o que está debaixo da flor, para o que está debaixo do pombo que voa, por cima dos cereais, debaixo da língua, dentro do sino, dentro do canhão, por detrás da cortina e no meio da sua borla.\}

Vozes de baixo: Não olhem para os troncos

Vozes de crianças: mas para o que há entre eles.

Vozes de contralto: Para o que está debaixo da mesa

Soprano: \{para\} o que está em cima do telhado,

Tenor: debaixo da flor,

Criança: debaixo do pombo que voa, 
Baixo: por cima dos cereais,

Vozes de contralto: debaixo da língua dentro da boca,

Soprano: dentro do sino,

Vozes de contralto: dentro do canhão,

Criança (muito alto) por detrás da cortina

Baixo (muito profundo) e-no-meio-da sua borla.

\section{$[25]^{*}$}

\{a "Kamarinskaja" que de repente termina.

\section{PAUSA (1)}

A pouco e pouco, surge uma luz suave como ao nascer do dia.

Avista-se uma rua sem graça. Grandes casas, desinteressantes, baixas, um pouco sujas com janelas pequenas**: \{das quais saem pessoas de tempos a tempos.\} formam o plano de fundo. Bastante à frente à esquerda está aceso <esparsamente> um candeeiro de rua que um homem manipula com o apagador extinguindo-lhe a chama. <Apesar disso, está claro.> Da esquerda e da direita chegam diversas pessoas < como as de hoje>. Muitas cumprimentam-se. À esquerda em cima, <(frente à casa)> aparece o sol anterior, mas que agora é prateado.

Um homem do realejo (vem da esquerda, ocupa-se durante bastante tempo com o seu realejo, a colocá-lo bem à frente junto ao candeeiro. Vai dando à manivela - nenhum som. Ele sacode-o-nenhum som. Ele empurra-o ora para a direita, ora para a esquerda - nenhum som. Ele pega no realejo, põe-no às costa e sai

\section{[26]}

pela esquerda. Enquanto isto acontece, todas as janelas se fecham, apenas aqui e acolá caminha depressa rua fora uma pessoa, sem olhar para o homem do realejo. Depois de ele se ter ido embora, o trânsito também acaba. O sol lança raios coloridos em todas as direcções. Absorve-os e volta a lançá-los.
*Ver p. $24 b$

**: [Este acrescento encontrava-se na margem esquerda do manuscrito:] 0 céu - comprimido, nuvens cinzentas escuras parecidas com salsichas. 
Atrás do palco cai qualquer coisa com estrondo. I sol desaparece.

Uma mulher gorda (abre uma janela no $\left\{3^{\circ}\right\} 1^{\circ}$ andar* e agita-a [?] com o pano de pó.)

Um homem jovem (abre uma janela no rés-do-chão, olha na direcção da mulher e ri alto.)

\section{A mulher Imbecil!}

O homem jovem (lisonjeador) Que mulher tão gorda! Heh! Heh! Uma mulher tão gorda assim até pode... oh! Perdão!

A mulher (fecha a janela com estrondo.)

\section{[27]}

O homem do realejo (aparece da direita, instala com rapidez e destreza os seu órgão)

O homem jovem (fala-lhe com convicção) Ora bem! Tem toda a razão: aqui ele vai soar.

O homem do realejo (começa a dar à manivela que de imediato emite uma série de sons estridentes, grosseiros. Acontecem sucessivas interrupções, durante as quais \{ele diz\} o jovem homem fala)

O homem jovem Bom! Bom! É isso, é isso! À esquerda não soa... nunca... À direita... já... soa... À esquerda nunca!.. À direita... soa! <(isto é dito muitas vezes)>; ele começa por dizer algumas frases com rapidez, outras de forma muito expressiva, outras apenas murmuradas, a seguir quando diz "à esquerda nunca», "à direita já", de forma acentuada e enérgica, apontando com o dedo para a esquerda e para a direita; a seguir, silencioso, ele deixa passar algumas pausas no silêncio, parece preocupado, olha para cima, para baixo, esfrega a testa e grita de repente aliviado: "esquerda! nunca! direita! jááa!! Depois a sua maneira de falar torna-se mecânica...
* N. B.: A altura do andar orienta-se conforme o palco: quanto mais alto, melhor) 
... entretanto todas as janelas, umas a seguir às outras, se abrem; pessoas muito diversas
* 2-3 passos, a seguir descansar, cuspir, limpar o suor, assoar o nariz, etc.

\section{[29]}

tornam-se visíveis). A pouco e pouco todos falam com o homem jovem:

À esquerda nunca! (de forma doce, misteriosa)

À direita já! (gritado e em fúria)

Pelo meio apenas o órgão.

Da esquerda aparece um enorme carrinho de mão branco, em cima dele uma cómoda, por cima da cómoda um papagaio numa gaiola dourada. O carrinho de mão é empurrado com grande esforço por operários." Ao mesmo tempo volta a aparecer na esquerda em cima e no seu lugar anterior, o sol que agora é prateado. Do chão, vinda da direita sobe uma lua vermelha e prossegue por cima na direcção das casas. O homem do órgão está rodeado de luz azul. De repente um terrível estrondo. Tudo permanece como que petrificado.

\section{[30]}

Os operários (cantam de forma arrastada e mecânica):

Da esquerda apareceu qualquer coisa.

O papagaio (grita) Bom dia!

As pessoas (à janela falam em uníssono de maneira entrecortada)

Ah! Pa-pa-gaio gentil!

(escuro; 5" depois ouve-se em voz abafada)

Ah! Pa-pa-gaio gentil!

$<$ Uma voz alta e irritada: E afinal veio do lado esquerdo!>

\section{[QUADRO] VII}

Não há nada no palco, fundo cinzento, bastidores laterais amarelos (ocre). Entram, pela direita, 2 criados de libré e transportam uma mesa posta (pratos a fumegar, garrafas). Põem-na à esquerda e dispõem tudo. Da direita espreita um limpa-chaminés que faz: 
Pst! Pst!

Os criados olham para ele.

O limpa-chaminés acena com o dedo.

Os criados pegam na mesa e voltam a sair com ela.

\section{PAUSA}

Os mesmos criados vêm da esquerda e trazem uma maca, em cima da qual está alguém deitado, eles colocam-na à direita. Da esquerda vem o limpa-chaminés e a mesma cortina.

\section{PAUSA}

A seguir a maca da esquerda e a mesma cortina.

\section{PAUSA}

\section{[32]}

O cavalheiro da cartola chega da direita.

A dama gorda da esquerda.

Eles colocam-se junto à ribalta, ficam de pé por uns momentos, olham à volta, olham um para o outro, riem.

O cavalheiro Ufa! (sai rapidamente)

A dama (levanta muito os ombros, boceja para o lenço de assoar, segura as suas saias e desaparece rapidamente).

\section{PAUSA}

Atrás do palco voz alta de criança: O Baluarte! O Baluarte! 5 Kopeks! O Baluarte! O próximo Baluarte! O próximo e muito novo Baluarte!! 
Uma voz masculina surpreendida:

A-a-a!

Munique - Murnau 1914 


\section{APOTEOSE}

1914

\section{Apoteose}

Por cima do chão azul que \{era\} é <irregularmente> amarelado, forma-se no meio um pontinho vermelho.

Fios brancos \{estendiam-se\} estendem-se em conjunto a partir dos cantos em direcção a este pontinho.

Uma forma oval verde estridente corre para cá e para lá, em todas as direcções, a partir do chão azul.

Só que ela não \{conseguia\} consegue aproximar-se do pontinho vermelho: ela aproxima-se bastante - quanto mais próxima, maior o seu esforço - mas volta outra vez para trás.

Em seguida ela rola $\{v a\}$ quase horrorizada por cima do chão azul.

Os fiozinhos brancos estremecem e parte deles \{tinham\} têm de fugir de novo para os cantos.

Até voltarem a ter novas forças - a seguir voltam a tentar aproximar-se do pontinho vermelho. E de cada vez, nesse exactro momento, o pontinho estremece $\{$ ia $\}$, tornando-se maior e de novo

\section{[2]}

mais pequeno.

É então que do canto inferior direito aparece uma mancha violeta, que tem \{tinha\} a forma de um 8 desmanchado. Ela desloca-se \{deslocava-se\} com cautela ao longo da borda do chão azul - por baixo, de lado, por cima, e passa a um movimento oval. Quanto mais pequena a forma oval, mais rápido é o movimento. Esquecendo-se de si próprio, o 8 contorna \{contornava\} o pontinho vermelho, sempre cada vez mais depressa e cada vez mais perto. A mancha verde \{estava\} está instalada no canto superior esquerdo e aguarda $\{v a\}$ os desenvolvimentos.

Eis que o 8 toca $\{v a\}$ no pontinho e dá-se uma estrondosa explosão que abala \{va\} o chão azul. \{O que é que restou dele?\} O azul desapareceu e o chão tornou-se vermelho, agitado por uma violenta vibração. A forma verde oval dissipou-se.

Os fiozinhos brancos tornaram-se 
invisíveis. \{Amigos, descubram o vermelho! Gentes, o azul não desapareceu!\}* No meio do vermelho acontece uma nebulosidade. Lentamente nasce um triângulo preto, que a pouco e pouco inclina a sua extremidade para a direita, se torna mais estreito, em baixo redondo, o lado esquerdo inchado de forma irregular, o lado direito balançando para dentro aos tropeções. A extremidade expande-se, alonga-se cada vez mais e forma um bico palpável, que inseguro, como que cego, tende para o canto direito que quase alçcança. A parte inferior dirige-se para a esquerda e para baixo e faz crescer os seus arredondamentos. Ao mesmo tempo, o azul misturou-se com o vermelho em cima à esquerda e lembra vagamente o 8 .

Um traço direito e branco vôa com toda a rapidez de baixo à direita para cima à esquerda e atravessa o 8.

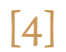

Uma quantidade de manchas coloridas mostra-se em diversas combinações e em diversos lugares.

O vermelho esmurece.

À direita, bastante em baixo, junto à margem, cresce rapidamente um grande círculo verde a partir de um ponto.

Todo o quadro se põe a girar: ele vira-se sobre o lado esquerdo que fica para baixo; então a parte de cima já é parte de baixo. Ainda uma rápida rotação. Outra ainda. Outra e outra ainda.

Cada vez mais depressa. Todo o quadro gira como uma roda - aumentando a velocidade.

Ouvem-se estalidos de chicote. Cada vez mais altos e mais rápidos. As cores e os sons desatam a correr de forma selvagem.

Sempre cada vez mais rápido. Todo o quadro anda à volta como se fosse uma roda - aumentando a velocidade.

Ouvem-se estalidos de chicote. Cada vez mais altos e mais rápidos.

As cores e os sons desatam a correr de forma selvagem.

Um tiro. Tudo \{fica\} escuro e imóvel.
* [Este acrescento do autor encontra-se na pág. 2 verso:] para a pág. 3. Por detrás do palco:

Homens (em tom de recitativo) Ve(!)jam, ve(!)jam, vejam(!) O verrrrrr-me-me-me-me-lho (Este "ver" rola glissando para baixo e termina a seguir)

Mulheres (sobre o tom do recitativo) Não-de-sa-pa-re-cer (em tom agudo) O-o-o- a-a-a-zul-zul-zul 


\section{VIOLETA;}

\section{QUADRO VI}

[1]

\section{QUADRO VII ${ }^{36}$}

Fundo liso cinzento. No meio uma pequena porta com uma cortina violeta. À direita na parede um quadro (paisagem de um verde venenoso) com moldura dourada. Bastidores laterais em amarelo ocre. A luz branca e uniforme.

Um servo assalariado chega da esquerda em passo rápido. Em direcção a ele um segundo. Ambos de libré vermelha. Ficam no meio do palco de pé e saem pela pequena porta do meio. Trazem para palco, da esquerda, uma pequena mesa redonda e colocam-na à esquerda a partir do meio do palco. Em cima da mesa dois couverts, uma garrafa de champanhe e um ramo de flores vermelhas.

Os criados arranjam a mesa.

\section{Escuro (5)}

A mesma cortina, mas da direita.

\section{Escuro (5)}

A mesma cortina - de novo da esquerda.

\section{Escuro (5)}

O cavalheiro da cartola vem muito pensativo da direita.

A dama decotada também da esquerda.

Eles encontram-se no meio do palco e seguem em direcção à margem da ribalta. Duraqnte alguns segundo olham para os espectadores- Depois olham um para o outro.

O cavalheiro (baixinho): Vamos acabar...

A dama eleva muito os ombros, boceja para o lenço de assoar, (cansada): Oh, claro!

Ambos deixam o palco de braço dado (pequena porta). 


\section{PAUSA (10)}

Uma voz forte de criança (por detrás do placo) O Baluarte! O Baluarte! 5 Kopeks! O Baluarte! O próximo Baluarte! O próximo e muito novo Baluarte!!

A pouco e pouco escuro total (5)

Uma voz de mulher (atrás do palco, voz forte, espantada, ansiosa)

A-a-a-a-a!

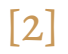

Fundo - branco. No meio do palco - um grande triângulo preto. Diante do triângulo - um banco vermelho comprido. Sobre o banco - duas fifguras todas cinzentas.

Primeira Figura: ... é sempre assim que tudo continua.

$2^{\text {a }}$ Figura: Sim! É sempre assim que tudo continua.

$1^{\text {a }}$ ": Como assim?

$2^{\text {a ": }}$ Quero dizer: é sempre assim que tudo continua.

$1^{a}$ “: O que é que isso quer dizer: é sempre assim que tudo continua?

$2^{\mathrm{a}}$ “: Sim! Quero dizer... Foi você que disse: é sempre assim que tudo continua!

$1^{\text {a } ~ ": ~ A h, ~ b o m ! ~ S i m ! ~ E u ~ d i s s e ~ i s s o: ~ e ́ ~ s e m p r e ~ a s s i m ~ q u e ~ t u d o ~}$ continua.

$2^{\mathrm{a}}$ “: E eu também disse isso: é sempre assim que tudo continua.

$1^{\text {a } ~: ~ C o m o ~ a s s i m ? ~}$

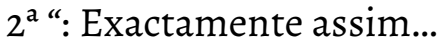

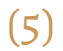

$\mathbf{1}^{\mathbf{a}}$ Figura: Eu não compreendo... A luz deveria ter ficado esverdeada na altura de «exactamente assim»...

$2^{a}$ ": Não é do conhecimento geral que «exactamente assim" corresponda a esverdeado.

Elas sussurram qualquer coisa uma à outra, levantam-se e em conjunto voltam-se para a sala de espectáculo 
Ambas: "Exactamente assim» é esverdeado.

Luz - esverdeado.

$\mathbf{1}^{\text {a }}$ Figura: Hoje apanhei um choque. Sabe que agora, mesmo em

círculos restritos, é preciso usar colarinho engomado com os cantos das pontas dobradas?

$2^{\text {a } ~ ": ~ M a s ~ a s ~ p o n t a s ~ s a ̃ o ~ m u i t o ~ m a i s ~ p o n t i a g u d a s ~ d o ~ q u e ~ h a ́ ~} 14$ anos.

$1^{\text {a }}$ ": Ah, sim?

Voltam a sussurrar, levantam-se e

Ambas as figuras: "pontiagudo" é amarelo.

De cima, da teia, vem um grande triângulo em forma de flecha, fica suspenso por cima da figura, à esquerda, e torna-se amarelo estridente.

$\mathbf{1}^{\mathrm{a}}$ Figura: Funciona bem.

$2^{\mathrm{a}}$ “: O que é que funciona bem?

$\mathrm{I}^{\mathrm{a}}$ “: O amarelo pontiagudo desceu no momento certo.

$2^{\text {a }}$ ": De acordo!.. Mas como ainda podemos usar o colarinho mole em casa, seria preciso então também que aparecesse o azul.

$1^{\mathrm{a}}$ “: Porque «mole» é azul?

De cima, da teia, vem uma forma oval em posição vertical e permanece suspensa por cima da figura à direita.

Ambas as figuras: Ora aí está. Isto resulta às mil maravilhas!

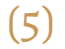

$\mathbf{2}^{\mathbf{a}}$ Figura: (muito satisfeita) Finalmente consigo compreendê-la! Disse e muito bem: é sempre assim que tudo continua. 
As duas luzes apagam-se.

$\mathbf{1}^{\text {a }}$ Figura: Do amarelo

A forma amarela brilha.

$\mathbf{2}^{\text {a }}$ Figura: Passemos ao azul

Sai o amarelo, ilumina-se a forma azul. Isto repete-se por três vezes: do amarelo para o azul, do azul para o amarelo, do amarelo para o azul.

Ambas as figuras: Às vezes misturam-se.

O amarelo e o azul desaparecem. Da frente aparece um verde forte.

Ambas as figuras: $O$ verde tédio.

\section{Escuro.}


SOBRE A SÍNTESE ABSTRACTA PARA PALCO

\section{[1]}

[CARIMBO DE DATA:] 30 DE JULHO DE 1923

\section{Sobre a síntese abstracta para palco}

$<$ W. Kandinsky $>37$

O teatro esconde em si um estranho íman com um estranho e oculto poder.

Mais do que uma vez, esse íman tem sido capaz de gerar uma tal tensão que aparentemente poderia conduzir a uma emocionante participação mais intensa.

Mas à ascensão seguiu-se o declínio, e uma crosta firme e fria formou-se sobre o ser interior do teatro.

Exactamente hoje em dia, esta crosta tornou-se tão poderosa, espessa e fria, que a força pulsante parece paralisada há séculos.

Hoje mais do que nunca, faz sentido que falemos do declínio do teatro. Não é por acaso que se lhe viram as costas com indiferença e o rosto esperançoso se volta, não por acaso, para o teatro de variedades, para o circo, para o cabaret ou para o cinema.

As antigas formas teatrais - drama, ópera, ballet - tornaram-se formas museológicas endurecidas e apenas podem produzir efeito como objectos em museu. Tudo o mais elas perderam..$^{38}$

E apesar disso, o dia de hoje é o limiar de uma nova ascensão que ultrapassará de longe na sua grandeza germinal e futura todas as anteriores elevações.

O íman oculto tornar-se-á vivo e a sua pulsação será cada vez mais perceptível. Do exterior acorrerão em seu auxílio novas armas afiadas para fazerem ir pelos ares a dura crosta.

O edifício (arquitectura), que não pode existir se não for colorido (pintura), e que a qualquer momento é capaz de fundir divisões de espaço (escultura), aspira através das suas portas abertas caudais de gente e ordena-os de forma esquemática em filas.

Todos os olhos vão na mesma direcção, todos os ouvidos se voltam para uma mesma fonte. A suprema tensão receptiva à espera de ser descarregada.

Esta é a possibilidade exterior do teatro, que aguarda por uma nova forma.
37 [O nome foi inserido à mão. A letra não se conseguiu identificar. Todos os erros ortográficos da mesma caligrafia foram corrigidos.] (Boissel, 1998: 282.)

38 Ver a propósito o ensaio Sobre Composição para Palco incluído nesta edição. (N. T.) 
Neste mundo isolado de tensão encontra-se um outro mundo isolado, para o qual estão voltados olhos e ouvidos - o palco.

Este é o centro promissor do teatro que, devido à suprema tensão da sua própria vida, deverá libertar as filas expectantes de espectadores da mais elevada tensão.

A capacidade de absorção deste centro é infinita - devido às suas extremas tensões, ela é capaz de comunicar todos os poderes de todas as artes às filas expectantes.

Esta é a possibilidade interior do teatro, que aguarda por uma nova forma.

O conjunto das diferentes artes actuais é absorvido desde há décadas pelas suas próprias energias. Elas desmantelam de forma implacável os seus próprios meios até às últimas consequências e verificam esses meios, de forma consciente ou inconsciente, em relação a uma escala interior.

Esta é a fase da grande análise que proclama em voz alta agrande síntese. A fragmentação deve estar ao serviço da recomposição. A desmontagem - a reconstrução.

Eis como se apresenta hoje o "grande mundo» e os pequenos mundos que nele vivem, reflectem exactamente os seus destinos. Este destino tem de ser partilhado pelo teatro.

Toda a arte tem uma linguagem própria e meios que lhe estão adequados - a sonoridade interior abstracta dos seus elementos. Nesta sonoridade interior abstractab não é possível substituir nenhuma das linguagens por outra. Assim, toda a arte abstracta é basicamente diferente das outras. É nisso que reside a força do teatro.

O íman escondido do teatro tem em si o poder de atrair todas as outras linguagens, todos os meios das artes que, em conjunto, oferecem a maior possibilidade da arte abstracta monumental.

\section{Palco:}

1. Espaço e dimensão - os meios da arquitectura - 
a base que permite a cada arte elevar a sua voz, para que surjam frases comuns, 2. a cor é indissociável do objecto - os meios da pintura - na sua extensão espacial e temporal, muito em particular na forma da luz colorida,

3. as extensões espaciais individualizadas - os meios da escultura - com a possibilidade de estruturar positiva e negativamente o espaço,

4. a sonoridade organizada - os meios da música - com as suas extensões temporais e espaciais,

5. o movimento organizado - os meios da dança - movimentos temporais, espaciais, abstractos, não apenas individuais, mas do espaço, das formas abstractas, que estão sujeitas a leis próprias.

6. Po fim, a última forma de arte que conhecemos, que ainda não descobriu as suas origens abstractas - a poesia - coloca à nossa disposição a palavra humana em toda a sua extensão temporal e espacial.

Da mesma maneira que a escultura se funde parcialmente na arquitectura, o mesmo acontece com a poesia que se funde parcialmente na música. No sentido mais restrito, a pura forma abstracta do teatro é a somadas sonoridades abstractas:

1. da pintura - a cor

2. da música - o som

3. da dança - o movimento

na ressonância comum da forma arquitectónica.

É aqui que começa o palco abstracto que pode conduzir às formas puras da composição para palco abstracta, o que em breve acontecerá, e para o qual o período analítico de todas as artes representa um primeiro passo inevitável.

As artes, que manterão uma vida própria, e para as quais o período analítico é igualmente importante e indispensável, poderão estar ao serviço do palco de um modo puramente sintético. Neste caso, ela renuciarão aos seus próprios objectivos, para que se sujeitem à lei da composição para palco, a qual, como as outras artes, estabelecerá o seu novo modus operandi apenas com o apoio 
da teoria da arte.

Os métodos da ciência da arte, das diferentes artes e da arte teatral sintética matêm-se os mesmos, i. e., eles devem abranger três questões principais:

Em particular, no palco:

1. Os elementos do palco e as suas forças interiores - elementos básicos, elementos acessórios, etc., i. e., um exame exacto e sistemático dos valores abstractos,

2. A lei de construção - a estrutura dos elementos de palco que do mesmo modo pressupõem experimentação científica pura,

3. a lei de subordinação de ambos os elementos e da estrutura com vista aopropósito interior da obra: composição.

É preciso que sejam criados laboratórios de teatro, onde os elementos individuais sejam experimentados em função e na óptica do teatro. Uma montagem esquemática dos diferentes elementos deve revelar e permitir avaliar as forças e os meios da construção, a regra principal a aplicar deverá ser a do contraste, no sentido de uma convergência e de uma divergência dos elementos - a considerar as ligações entre cor, som e movimento e a sua acção concertada no tempo.

Estes estudos preparatórios servirão o espírito criador como ferramentas para a criação da obra viva da arte. 
[1]

\section{MUSSORGSKY - "QUADROS DE UMA EXPOSIÇÃO"}

encenados por Kandinsky,

com orquestração de Muralli (?) ${ }^{39}$

Este texto deve ser sempre comparado com as indicações da parte correspondente ao piano, pois ambos se completam mutuamente.

\{Os números entre parêntesis () a referência aproximada em segundos.\}

As letras acompanhadas dos números indicam: a página p., o lado correspondente e a respectiva linha do excerto da partitura para piano, P.. Os diferentes quadros estão numerados a lápis vermelho em cada excerto. As dimensões da abertura para palco estão indicadas nos desenhos.

Em todos os quadros (à excepção eventual do Quadro 13 - Catacombae), o fundo de palco está coberto por uma cortina de pelúcia preta que causa a impressão de uma profundidade imaterial.

\section{QUADRO 1 - PROMENADE}

Aos primeiros acordes da música, abre-se o pano de boca. O palco apresenta-se de uma profundidade negra indefinida e imaterial. Bastante à frente nesta obscuridade está suspenso um círculo ainda não iluminado (com 2 metros de diâmetro), que é feito de um tecido translúcido colorido a vermelho, por detrás do tecido estão algumas lâmpadas vermelhas (o vermelho é cinábrico) que ao segundo compasso (p. 5; P. 2) se começam a iluminar lentamente e que ao primeiro compasso (P. 4) alcançam incandescência máxima.

No segundso compasso (P. 5) a incandescência diminui.

Ao terceiro compasso (P. 6) a luz vermelha apaga-se e o círculo é içado para a teia.
39 [Existem informações muito contraditórias no que diz respeito à partitura utilizada na versão orquestral da representação. Tratava-se de uma orquestração de Maurice Ravel (1922) ou de uma versão ciontemporânea? O nome referido (Muralli) poderia ser uma deturpação do nome do então maestro da orquestra do Teatro de Dessau, Alfons Mourot.] (Boissel, 1998: 292.) 
(Os números entre parêntesis são segundos mas apenas a a título aproximativo). O palco não está iluminado, está portanto escuro, assim permanecendo durante os 10 primeiros compassos.

(Ver o excerto da partitura para piano para indicações mais precisas!)

As listras horizontais tornam-se visíveis (ilumonadas detrás a branco), (15).

Escuro!

As listras verticais tornam-se visíveis (15).

Escuro!

O fundo branco torna-se visível, e a partir de $s f$ (sforzando) (p. 6; P. 3) a pequena figura negra (III) é endireitada (até então ela estava suspensa virada para baixo e não se distinguia no meio do fundo negro, ela é puxada pelo fio) (30). Em Poco negro... (P. 5) a figura colorida (IV) é também elevada da mesma maneira. Imediatamente a seguir a figura em forma de grade $(V)$ é baixada a partir do alto. Em Vivo (p. 7; P. 1), o círculo é descido, está iluminado por dentro.

Ao entrar sempre ff(P. 2) tudo desaparece.

2 a 3 compassos depois, vemos reaparecer ao mesmo tempo as listras horizontais e verticais.

Em poco a poco (P. 3) todo o quadro se torna visível.

Em Sempre vivo e, especialmente ao ritmo fff(P. 5 e 6), luz muito forte.

Escuro! (em velocíssimo)

Em velocíssimo, o círculo vermelho é descido lentamente e permanece sem iluminação.

NB! A complexa figura IV pode ser pintada de branco, que se mantém invisível sobre o fundo branco (fundo de cena). Assim consegue-se que o conjunto das partes coloridas da figura IV apareça ao mesmo tempo no momento em que ela é levantada.

\section{Mussorgsky}

\section{QUADRO 3 - PROMENADE}

Tudo negro. O círculo vermelho invisível está contudo pendurado (cf. Quadro 2!).

Ao terceiro compasso (p. 8; P. 1), ou seja, em più piano, o círculo é iluminado de um vermelho de intensidade média e de dentro, segue-se uma fraca luz azul que é projectada de cima sobre o círculo vermelho - criando uma espécie de de violeta. 
Em ritardando (P. 3) a luz vermelha do interior apaga-se e no último compasso também o violeta desaparece.

Escuro!

\section{QUADRO 4-O VELHO CASTELO}

\section{Escuro!}

Em espressivo (p. 8; P. 5), as três listras verticais tornam-se visíveis. (Elas são iluminadas por trás, dito de outro modo, por transparência!).

No último compasso da p. 9, P. 1, as listras desaparecem (i. e., o painel não é içado e as listras tornam-se quase invisíveis).

Em espressivo (P. 29) a superfície vermelha é empurrada da direita para cena (ela é de um vermelho suave - semelhante ao vermelho inglês - mas no momento da sua aparição, ela é iluminada de cima (ou da direita) por um feixe de luz vermelho intenso e frio que deverá produzir um efeito de tonalidade vermelha muito profundo e grave).

No final do terceiro compasso (P. 2), entra agora da esquerda a superfície verde, iluminada a verde (luz suave de um verde profundo).

Ao primeiro compasso (P. 5), a figura IV reaparece do alçapão; a partir do momento em que ela se mostra totalmente visível, é iluminada do interior, por transparência, através de uma luz colorida.

(Se não houver alçapão, esta figura pode eventualmente também entrar pela direita.)

Ao quarto compasso (P. 6) a figura $\mathbf{V}$ entra em cena empurrada da esquerda e, ao mesmo tempo, a figura VI (já iluminada do interior) é baixada do alto. Pouco depois, os pequenos triângulos da figura $\mathrm{V}$ são iluminados por transparência.

Em espressivo (p. 10; P. 4), a figura VII é trazida da direita para cena (atrás da figura encontra-se um manipulador, que levanta a figura VIII, uma vez que ela steja em equilíbrio). Ela é imediatamente iluminada por transparência.

Em poco largamente, a iluminação baixa progressivamente.

Em p (p. 11; P. 1), escuro!

Em expressivo (P. 2) as três listras brancas

\section{[3 VERSO]}

reaparecem como no início do quadro.

$\operatorname{Em~f(P.3),~escuro!~Uma~cortina~preta~intermédia~cai~}{ }^{40}$ 


\section{QUADRO 5 - PROMENADE}

Diante da cortina preta intermédia, um longo rectângulo branco é transportado devagar da esquerda para a direita (ele deve ser mantido bem na vertical! e se possível fazê-lo deslizar suavemente!).

A iluminação branca frontal vinda de baixo deve ser muito fraca (a luz proveniente do fosso de orquestra pode ser suficiente). A atmosfera deve ser crepuscular, como se de um sonho se tratasse!

Este deslizamento tem início durante o primeiro compasso da Promenade, terminando ao penúltimo compasso (o último compasso soa já no escuro).

\section{QUADRO 6 - TUILERIES}

Um écran branco é colocado a média profundidade do espaço cénico, sobre o qual é usado um projector que ilumina detrás um caleidoscópio.

O caleidoscópio deve ser fortemente colorido, mas em tons alegres e divertidos. A rotação começa com o primeiro compasso do quadro e termina com poco ritardando (p. 13; P. 2). Volta a fazer-se escuro e o écran branco é retirado.

A velocidade da rotação e a intensidade da iluminação estão indicadas com precisão no excerto da partitura para piano:

As letras $H, S$ significam "mais claro" $[\mathrm{H}=$ hell = claro] e "mais rápido" [ $\mathrm{S}=$ schnell $=$ rápido ,

As letras D e L significam "mais sombrio" $[D=$ dunkel = sombrio $]$ e mais lentamente $[L=$ langsam $=$ lentamente $]$.

\section{QUADRO 7- BYDLO}

As diversas figuras estão indicadas através de números romanos na partitura para piano e também no desenho.

Bastante à frente e em baixo é colocada uma parede preta de 1,5 m de altura, sobre a qual as diferentes figuras (à excepção de VII e VIII) se movem ao som da música (por trás desta parede pode haver manipuladores que deslocam as figuras sobre a parede).

Figura 1 está em palco ao primeiro acorde do quadro. As outras figuras estão marcadas na partitura para piano e surgem uma a uma, de tal modo que com o rápido aparecimento da figura seguinte ainda é visível a anterior (dito de outra maneira: enquanto uma sai devagar, a outra já está em cena, etc.).

Figura VI move-se sozinha longamente. 
Figura VII rola lentamente no chão diante da parede preta, também sozinha e é iluminada por uma luz branca.

Figura VIII está suspensa no ar, mais elevada do que as seis primeiras (ela pode estar pendurada por um fio).

Em ppp (p. 15: P. 2) a figura VIII desaparece e a luz apaga-se. Escuro!

À excepção da Figura VII, todas as figuras são iluminadas por uma luz crepuscular brtanca-esverdeada (eventualmente de frente em baixo.

Todas as figuras devem causar um efeito de imaterialidade pairando na incertitude.

A Figura IV tem um movimento um pouco vacilante. A Figura VIII move-se um pouco de forma ondulatória.*

* [Indicações à mão de Kandinsky, em fim de página:] As Figuras III e V movem-se aos solavancos. [E na margem esquerda:] NB! No desenho de luz, a iluminação das diferentes figuras é diferente. Se a estrutura de iluminação do teatro for suficiente, estas instruções devem ser seguidas!

\section{[4]}

Mussorsgky

\section{QUADRO 8 - PROMENADE}

No palco atrás é colocada uma tela ou um painel em cartão de $2 \times 2 \mathbf{m}$, de cor preta em que estão recortadas listras ondulantes de 10 a $15 \mathrm{~cm}$ de largura (cf. com o desenho!)

Durante os oito primeiros compassos, desloca-se em movimento amplo por detrás da parede uma luz azul (lanterna de bolso) sobre as listras superiores, o que produz uma iluminação errante na escuridão. Se necessário, esta luz pode movimentar-se também sobre a segunda (a contar de cima) série de listras.

Os dois últimos compassos no escuro!

\section{QUADRO 9-BAILADO DOS PINTAINHOS DENTRO DAS SUAS CASCAS DE OVO}

Ao primeiro compasso 3 luzes amarelas movem-se muito rapidamente ao longo das listras da direita em baixo para cima (elas movem-se de forma ascendente). A música dá o ritmo: em f (p. 16: P. 3) todas as 3 já têm de estar no alto.
* [Indicações à mão de Kandinsky, em fim de página:] As Figuras III e V movem-se aos solavancos. [E na margem esquerda:] NB! No desenho de luz, a iluminação das diferentes figuras é diferente. Se a estrutura de iluminação do teatro for suficiente, estas instruções devem ser seguidas! 
No trio (P. 4) cada uma das luzes vai e vem sobre as linhas I, III, V (cf. a partitura para piano!).

Em $p p$ (P. 6) as três luzes seguem as listras de baixo para cima.

Ao quinto compasso (p. 17; P. 1) as 3 luzes mantêm-se aglutinadas no alto à direita. Com a tempo elas voltam a descer.

Em f (P. 2) as luzes apagam-se. Escuro! A cortina intermédia preta desce durante a coda.

\section{QUADRO 1O - SAMUEL GOLDENBERG E SCHMUYLE}

Em palco 2 superfícies transparentes. Por detrás de cada uma destas superfícies um bailarino vestido com o traje judaico tradicional - sob o círculo vermelho um gordo rico, sob o círculo amarelo, um magro pobre.

Ao terceiro compasso (p. 17; P. 3) o círculo vermelho é iluminado de frente por uma luz branca e a cruz move-se lentamente (no sentido dos ponteiros do relógio). De resto escuro total.

Ao quarto compasso o bailarino é iluminado de trás, o que permite ver uma silhueta de perfil e imóvel. A iluminação do círculo desaparece no fim do $4^{\circ}$ compasso (P. 4) e o bailarino desaparece também.

Ao primeiro compasso (P. 5) o círculo amarelo é iluminado de frente a branco e a cruz que ele comporta vira-se rapidamente para a esquerda (ao contrário dos ponteiros do relógio).

Ao primeiro compasso (P. 6) o segundo bailarino é iluminado de trás e de perfil. Em andante grave (p. 18; P. 2) os dois círculos são iluminados de frente, eles movem-se como anteriormente.

Ao mesmo tempo e até ao último compasso do quadro, os dois bailarinos gesticulam como se estivessem a conversar de forma enérgica - o gordo com dignidade, o magro muito enervado, às vezes servil.

\section{[4 VERSO]}

\section{QUADRO 11 - PROMENADE}

Ao primeiro compasso surge a longa superfície branca (tal como no quadro V) e ela é empurrada bruscamente (de forma irregular), em sintonia com a música, da direita para a esquerda. Ela desaparece no início do terceiro compasso (p. 19; P. 6).

Escuro! 


\section{QUADRO 12 - O MERCADO EM LIMOGES}

Ao primiero compasso da música todo o quadro se torna visível - luz branca distribuída de modo uniforme. Os dois bailarinos estão de pé, cada um em cima de um palanque vermelho-branco-azul - no princípio em cima do degrau superior vermelho. Nada se move.

Com $s f$ (p. 20; P. 6) o bailarimo da direita salta do degrau vermelho para o azul. Ao mesmo tempo a luz faísca como um relâmbago.

Com $f$ o bailarino da esquerda salta também para o azul, acompanhado por um relâmpago.

Com $s f$ os dois bailarinos saltam do azul para o chão, relâmpago. Tem início a dança dos dois bailarinos que exprime: palmas, lutas, de novo reconciliação e palmas, etc..

Com $m f$ (p. 22; P. 1) é erguido o prospecto (plano da cidade) e os dois palanques são removidos para os lados. Ficam apenas os bailarinos sobre o fundo negro que está iluminado de cima por uma tonalidade azulada.

Seguindo a dança, cada um dos bailarinos é iluminado por um projector colorido mas suave. Ao terceiro compasso (P. I) o fundo de palco recebe a cor vermelha em vez da azul. Ao segundo compasso (P. 2) - verde.

Com $f$ (P. 3) tudo volta a ser iluminado a branco (inclusivé os bailarinos). Com $s f(\mathrm{P} .4)$ regressam todas as cores anteriormente mencionadas.

Com meno mosso (P. 5), as luzes mudam (de forma violenta!) num tempo rápido e desaparecem a partir do segundo compasso.

Ao primeiro compasso (P. 6) todas as cores desaparecem à excepção do branco. No meio da contenda, os cestos tinham sido colocados no meio do palco. Agora os bailarinos dirigem-se para os cestos, pegam neles apressadamente e saem do palco - para a esquerda e para a direita. Eles desaparecem com a última nota deste quadro.

\section{QUADRO 13 - CATACOMBAE}

Toda a primeira linha da música pressupõe uma mudança de cor antecipada. (Ver a informação na partitura para piano!)

A segunda linha destina-se à construção das figuras:

Figura I é empurrada da direita

Figura II vem da esquerda

Figura III vem da direita e é colocada junto a I 
Figura IV vem da esquerda e é colocada junto a II

Figura $V$ é descida de cima e apoia-se a III e IV.

Figura VI e VII de cima, mas ainda não estão iluminadas.\}

\section{QUADRO 13 - CATACOMBAE}

\section{Mussorgsky}

O fundo de palco é branco, vindo a colorir-se por diferentes luzes de cores variadas - atmosfera geral sombria.

Os 2 primeiros compassos no escuro.

A seguir o fundo de palco torna-se primeiro esverdeado (ton de base que permanecerá), ao qual se junta imediastamente o vermelho.

Quinto compasso vermelho, desaparece o verde! etc. - cf. partitura para piano!

A disposição das figuras será sublinhada através das luzes coloridas.

A disposição acontece de acorodo com a ordem numérica:

Figura I entra pela direita,

Figura II entra pela esquerda,

Figura III entra pela direita,

Figura IV entra pela esquerda,

Fifura $V$ desce do alto,

Figura VI desce do alto,

Figura VII desce do alto

(as duas últimas unicamente como no início do

\section{QUADRO 14- COM MORTUIS IN LÍNGUA MORTUA}

No início descem as figuras VI e VII, mas não estão iluminadas.

No meio do $2^{\circ}$ compasso (p. 23; P. 4) a figura VI é iluminada de dentro em vermelho, a seguir a figura VII em verde. O fundo quase não está iluminado.

Ao $3^{\circ}$ compasso (p. 24; P. 1) desaparecem as luzes coloridas! Quase escuro total. Os outros signos inscritos na partitura para piano indicam a alternânciadas luzes vermelha e verde sobre as figuras VI e VII.

No último compasso escuro!

\section{QUADRO 15 - A CABANA DE BABA YAGA}


O prospecto consta de três partes: meio - branco, as laterais a preto, nas quais estão recortados buracos (cf. desenho!), através dos quais são iluminados por lanternas de bolso (como nos Quadros 8 e 9).

Escuro total no início, estando a parte central branca oculta por um écran preto invisível. A figura que aí vai aparecer (IV) já está no lugar mas escondida.

Ao compasso $9^{\circ}$ (p. 24; P. 3) a iluminação processa-se como se fosse um relâmpago por detrás das duas partes laterais.

Ao compasso $3^{\circ}$ (P. 4) acontece a mesma coisa, mas 2 vezes.

Em $m f(P .4)$ os buracos compridos do lado direito são iluminados de baixo para cima e detrás, etc. Outras indicações ver a partitura para piano! (Também seria possível iluminar os buracos com cores - como indicado no desenho - o que poderia ser feito com diversas lanternas de bolso coloridas, se os meios técnicos o permitirem).

A parte central só se torna visível com o andante mosso (p. 27; P. 1) Tudo termina com ppp (p. 28; P. 4).

Para detalhes ver a partitura para piano.

Para as mudanças de cena do Quadro 16 dispomos de 4 minutos, o que é suficiente.

\section{Mussorgsky}

\section{QUADRO 16 - A GRANDE PORTA DE KIEV.}

As figuras I e II estão em palco desde o início, mas ocultas pela cortina preta intermédia. (Como com III e IV)

Apenas com fenergico (p. 32; P. 2) se sobe a cortina intermédia.

Durante o compasso seguinte o grande arco (figura V) é descido lentamente (!!).

Com $p$ (P. 5) a citadela (figura VI) desce lentamente (!!) sobre o arco.

Com crescendo (p. 33; P. 3) o grande prospecto desce lentamente (!!) pintado ao de leve por uma luz amarelada vindo de cima.

Com meno mosso (p. 34; P. 3) a figura III é deslocada para a esquerda, a figura IV para a direita (figurinos).

O sempre maestoso é sublinhado por fortes mudanças de luz.

Branco - Vermelho - Amarelo

Amarelo - Vermelho-Azul 
Com $m f$ (p. 35; P. 1) a iluminação é introduzida (lentamente!) e passa ao vermelho. Ao quinto compasso (P. 2) as figuras VII, VI e V são içadas (= desaparecem no alto). Com $f$ (P. 3) a luz torna-se num vermelho forte ( $f$ sob a luz!)

Com o primeiro compasso (P. 4) a luz vai sempre esmurecendo e com poco a poco... (P. 4) escuro! (A cortina-écran preta baixa.)

Com o terceiro compasso (P. 5) o círculo vermelho (como no quadro 1) desce, mas ele só é iluminado por transparência aquando de grave... (P. 5). Este vermelho do círculo alcança rapidamente a intensidade suprema (= ff da partitura musical!).

No segundo compasso (P. 6) a luz vermelha baixa e apaga-se no final do quinto compasso. (P. 6).

Durante os três últimos compassos a cortina exterior corre e fecha-se.

\section{Fim}




\section{$[1]^{41}$}

\{para Quadro VIII: É possível uma forte coloração se houver preto atrás e por cima dele luz espalhada?

As formas em maillot preto podem ser utilizadas?

É possível apontar alternadamente? P. 10 de «Gnomo»?

No velho castelo o sol e alua são transparentes e iluminados detrás. O castelo aparece isolado e em último lugar - elevando-se de baixo - com pontos brilhantes iluminados de trás.

Na dança dos judeus - alternância da iluminação em transparência = acentuada e difusa - por ex., mãos, cabeças etc. Por fim (último compasso) salto e imobilidade.

Limoges na dança - luta

$$
\begin{aligned}
& \text { conversa que } \\
& \text { degenera em luta } \\
& \text { pausa = saída }
\end{aligned}
$$

\section{[1 VERSO]}

VII Bydlo da direita para a esquerda em procissão (3)

em parte aos solavancos

em parte de forma suave

[esboço]

VIII Promenade [esboço] (30')

uma luz diante das listras

IX Pintainhos 5 listras onduladas [esboço]

1 em baixo à direita - esquerda

2 no meio à esquerda - direita

3 em cima à direita - esquerda

4 todas em conjunto apressadamente

$$
\begin{aligned}
& \text { direita - esquerda } \\
& \text { esquerda-direita. etc. }
\end{aligned}
$$

X Samuel Goldenberg e Schmuyle 1 1/2 compassos - círculo 


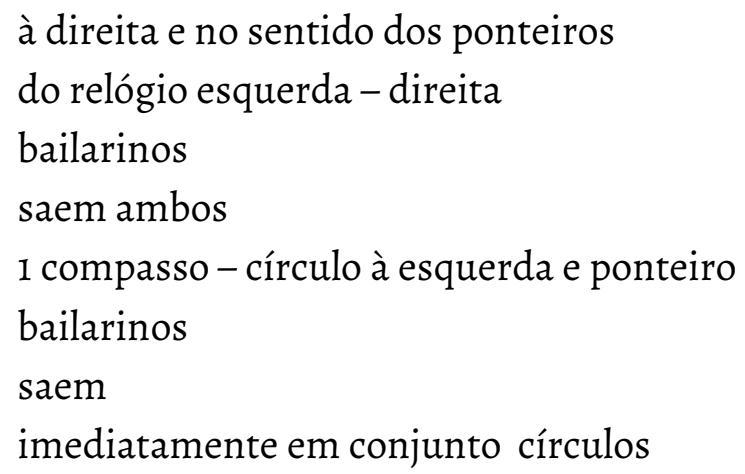

42 [Erro de numeração: é a figura 4 que aparece da direita e a figura 5 do alto.] (Boissel, 1998: 310.)

XI Promenade Luz sobre todo o palco. Fundo preto (90')

Verde-Vermelho-Amarelo... - Escuro

XII Limoges Plano preto/branco. Figuras francesas (1')

Por fim - o plano desaparece e o fundo torna-se

azul sombrio

Figuras - Projectores vermelho e verde (ou amarelo?)

XIII Catacombae Disposição:

Escuro

1. $f f$-vermelho $>$ p - vermelho-mate

2. crescendo a ff vermelho - $\mathrm{p}$ - verde-mate

3. $\int f \square 1$ da esquerda - verde forte por detrás

4. $\int f \square 2$ da direita - azul forte por detrás

$5 . p \square 3^{42}$ da esquerda e da direita - mais mate

6. $p p$ figura 4 de cima || ainda mais mate

7. poco a poco crescendo o azul aumenta

8. ff-azul profundo

9. último ff-vermelho forte e frio $>p$ - escuro

XIV Com mortis...

1. primeira linha - azul esvoaçante

$2 .{ }^{8}$ - - - - - verde [esvoaçante]

3. preto

$4 .^{8}-----$ azul + verde

5. p. 24 tranquillo - pequenas luzes

brancas (com a música) [esboço] 
substituindo-se umas às outras.

6. Último compasso - todas as luzes

XV Baba Yaga

1. Primeira frase até andante - luzes

multiculores que dançam

2. Andante - cabana

p. 27 o ponteiro move-se

3. Allegro-foguete

4. Luzes e alguns foguetes

\section{[2 VERSO]}

\section{Kiev}

[esboço] [anotado ao alto à direita :] "preto com irradiações"]

Até $f f 3^{a}$ linha da disposição: em primeiro lugar fundo preto

1. da esquerda superfície azul

2. $5^{\circ}$ compasso luz amarela sobre preto

$3.2^{\circ}$ compasso linha à esquerda prateado, à direita [esboço]

4. $3^{\mathrm{a}}$ linha $m f$ porta e cidadela

5. $3^{\mathrm{a}}$ linha crescendo [esboço] e direita [esboço]

6. ff sol e lua e de imediato tudo vermelho

7. $4^{\mathrm{a}}$ linha senza espressione vermelho e cinzento

8. p. $32^{8}-----$ a. as figuras desaparecem

b. as figuras desaparecem sobre sempre expressivo

c. as figuras desaparecem sobre

9. p. $342^{\text {a }}$ linha ${ }^{8}-----$ as figuras deslocam-se

Em sentido contrário

faz-se escuro, apenas duas listras azuis claras meno mosso - apenas as figuras - todas a preto e branco Atrás, mudança de cores muito profundas grave (p. 35) o círculo vermelho inflama-se três vezes, apagando-se em seguida. ${ }^{43}$

Recebido em: 15/09/2018 | Aprovado em: 30/10/2018

Revista do Laboratório de Dramaturgia - LADI - UnB - Vol. 9, Ano 3

Textos e Versões
43 [Todas estas indicações manuscritas complementares parecem ser de uma fase posterior. Elas não foram registadas na partitura para piano.] (Boissel, 1998: 312.) 